\title{
Twelfth Annual Meeting of the Czechoslovak Society for Microbiology
}

Abstracts of Communications

Košice, September $9-11,197 j$

GENERAL MICROBIOLOGY

On the Problem of Primary Damage of DNA in Escherichia coli after UV Irradiation. P. Balgaví, Faculty of pharmacy, Komenský University, Bratislava.

The photoreactivable sector of the lethal damage of cells caused by the UV radiation is defined as $\sigma_{\max }=1-D_{0} \cdot D_{\mathbf{x}}^{-1}$, where $D_{0}$ is a dose of UV radiation resulting in a survival of the same fraction of cells $S$ as that after an UV dose $D_{\mathrm{x}}$ followed by a maximal photoreactivation of cells. During the photoreactivation pyrimidine dimers $\left(\mathrm{Pa}<>\mathrm{Py}\right.$ ) are converted to monomers, hence, $\sigma_{\max }$ directly determines their role in the lethal damage of the cells. It was found that in Escherichia coli $B_{\mathrm{s}-1}$ $\sigma_{\max }=0.823 \pm 0.004$ at a $99 \%$ reliability interval, in agreement with the known $80 \%$ representation of $\mathrm{Py}<>\mathrm{Py}$ in the total amount of photoproducts detected in DNA of Escherichia coli. In Escherichia coli $\mathrm{B} / \mathrm{rH} \mathrm{Her}^{-} \sigma_{\max }=0.70 \pm 0.01$ at a $99 \%$ reliability interval could be detected. In Escherichia coli $\mathrm{B} / \mathrm{r} H c r^{+} \delta$ max was constant only within the region of $S<10^{-1}\left(\sigma_{\max } \doteq 0.48\right)$, increasing to a value of 0.70 with a decreasing UV dose within the region of $10^{\circ}>S>10^{-1}$. These changes, as well as the lower $\sigma_{\max }$ values in the $H c r^{+}$and $H c r^{-}$strains are not caused by changes in the spectrum of photoproducts but rather by a preferential removal of prelethal damage brought about by $\mathrm{Py}<>\mathrm{Py}$ as compared with the prelethal damage caused by other photoproducts. It follows from the experimental data that the excision repair mechanism is more selective in this respect than the non-excision one. In the strain Escherichia coli $\mathrm{B} / \mathrm{r} \mathrm{Her}+$ thy trp the $\sigma_{\max }$ value within the $S<10^{-1}$ region does not depend on whether the cells were irradiated during the exponential phase of growth or after a $40 \mathrm{~min}$ thymine or $120 \mathrm{~min}$ amino acid starvation. It thus follows that in all cases $\mathrm{Py}<>\mathrm{Py}$ are involved in the lethal damage of cells to the same extent. Changes in the UV resistance of the cells brought about by these preirradiation treatments are hence caused by changes in repair processes after the UV irradiation.

Demonstration of Non-Excised Dimers in the Replicated DNA of Cells of Escherichia coli $B / r \mathrm{Her}^{+}$. M. Sedliaková, J. Brozmanová, F. Mašek, Department of Molecular Genetics, Cancer Research Institute, Slovak Academy of Sciences, Bratislava.

It was found that the excision repair mechanism (excision of pyrimidine dimers from DNA of cells damaged by UV radiation) can be almost fully suppressed by 
acid starvation the above treatment not only does not influence viability of the cells but it does not influence their resistance to UV radiation either. The finding that depression of the excision mechanism does not result in a decreased survival of the cells after the $\mathrm{UV}$ irradiation indicates that this repair mechanism is not responsible for the high degree of resistance to UV radiation observed in cells of the $\mathrm{uvr}^{+} \mathrm{rec}^{+}$genotype. However, as the excision of dimers is determined in the whole population of cells, out of which only a minor portion survives, a possibility could not be excluded that the excision was suppressed only in the cells that have not survived, whereas a small portion of surviving cells excised quantitatively. Experiments, in which excision of dimers in DNA strands replicating after the irradiation and in strands that did not replicate after the treatment was studied are referred to in the present communication. Both types of strands were separated by means of density labelling followed by ultracentrifugation in a $\mathrm{CsCl}$ gradient. Dimers were determined by two-dimensional radiochromatography. The results showed that no substantial differences between the content of non-excised dimers in both types of strands exist. Thus, we confirmed the assumption, viz. that the excision of dimers is not responsible for the high degree of resistance of the $u v r^{+} \mathrm{rec}^{+}$cells.

The Role of Free Amino Acids in the Repair of Radiation Damage in Cells of Escherichia coli. B. Koukalová, Biophysical Institute, Czechoslovak Academy of Sciences, Brno.

Effect of amino acids on the repair of damage of bacterial cells caused by beta radiation of the incorporated ${ }^{3} \mathrm{H}$-thymine was investigated. Escherichia coli TAU-bar, requiring Arg, Het, Pro, Try, uracil and thymine, was used throughout. Cells with the incorporated ${ }^{3} \mathrm{H}$-thymine were incubated in a medium without amino acids and uracil at $0-3^{\circ} \mathrm{C}$. It was found that the number of cells capable of forming colonies on L-broth decreases exponentially with respect to the number of disintegrations of tritium, $D_{0}$ equalling about 80 disintegrations per cell. When the cells that accumulated tritium disintegrations at $0-3{ }^{\circ} \mathrm{C}$ are transferred to $37^{\circ} \mathrm{C}$ prior to plating onto Petri dishes and incubated in a medium without a required nutrient, the number of colony forning cells is influenced considerably. During a $1-2 \mathrm{~h}$ incubation in the medium without amino acids and uracil the number of cells capable of reproduction is sharply decreased to about $5 \%$ of the original value. The addition of uracil does nct influence this decrease. However, it can be influenced by the addition of amino acids. In the presence of amino acids (and in the simultaneous absence of uracil) the number of cells capable of reproduction decreases only to $50 \%$ of the original value. This effect, aithough to a lesser extent, is exhibited even by methionine alone. As in the incubation medium of the given composition (absence of uracil) the cells cannot synthesize RNA and proteins, the described results indicate that free amino acids are probably involved in the repair of the radiation damage.

Selection of UV-Revertants on Semi-enriched Medua. D. SLAmex̌ová, Department of Molecular Genetics, Cancer Research Institute, Slovak Academy of Sciences, Bratislava.

The work is of methodical character being concentrated on determination on the ratio of spontaneous and $\mathrm{UV}$-induced argine reversiors during their selection on semi-enriched selective media. Escherichia coli $\mathrm{H} / \mathrm{r} 30 \mathrm{R}$ served as a model micro- 
organism. The ratio of spontaneous reversions to induced ones was evaluated on the basis of reconstruction experiments, from the point of view of the degree of damage of the cells and their concentration on a selective medium. It was found that plating of low quantities of irradiated cells on a selective medium results in a situation, when the total yields of arginine revertants include considerable quantities spontaneous reversions originating during the postirradiation divisions of surviving cells. When the cell density in the studied samples is increased, the representation of the induced forms in the mixture of revertants increases and the number of the spontaneous forms is simultaneously decreased. The increase of percentage of the induced reversions depends on a radiation dose used for the induction of reversions.

The Relationsiip between Survival and Abiity to Synthesize a Complete Molecule of $D N A$ in Different Strains of Escherichia coli after UV Irradiation. V. SLEzÁRIková, F. Mašek, M. Sedliaková, Department of Molecular Genetics Cancer Research Institute, Slovak Academy of Sciences, Bratislava.

By means of centrifugation in a sucrose gradient it was possible to observe a relationship between capacity of cells to synthesize a complete molecule of DNA after the ultraviolet irradiation and their survival. Different strains of Escherichia coli (Escherichia coli B/r Hcr+, Escherichia coli 15 555-7, Escherichia coli K-12 SR20) exhibiting the excision and recombination repair but with a different sensitivity to the ultraviolet radiation have a different ability to join short regions of DNA synthesized after the irradiation. The longer the time interval required for synthesis of the intact molecule of DNA, the smaller the fraction of surviving cells.

The Life Cycle of Mycelial Fungi and Its Regulation. V. Betina, Department of Technical Microbiology and Biochemistry, Faculty cf Chemical Technology, Slovak Technical University, Bratislava.

The life cycle of sporulating filamentous fungi includes three main periods: germination of spores, mycelial growth and sporulation. These processes are a result of the interaction between the genetic information and impulses from the outer environment. Germination of spores is characterized by a generalized mobilization of the metabolism. Whereas during the period of dormancy most spores exhibit only a minimal metabolic turnover of structural and information macromolecules, already at the beginning of germination synthesis of proteins, RNA and DNA is rapidly increased. At least some non-germinating spores contain complete messenger RNAs ( $m$ RNA) that can immediately function in protein synthesis during the initiation of germination. The synthesis of new structures is followed by polarization leading to the origin of the first hypha and, thus, to the mycelial growth. The shape of the hypha is determined by the originating cell wall and its terminal growth proceeds as a cooperation of the activity of lytic and synthesizing enzymes. External impulses play a pronounced role in regulation of growth and branching of the hyphae. In dimorphic fungi environmental factors (temperature partial pressure of $\mathrm{O}_{2}$ and $\mathrm{CO}_{2}$, $\mathrm{SH}$-compounds etc.) determine, whether the germination of spores would be followed by the mycelial or yeast-like growth. Sporulation is the most common way of asexual multiplication of the mycelial fungi. It occurs usually when carbon sources are 
exhausted; however it can be regulated also by nitrogen sources. Sporulation of certain fungi (e.g. Trichoderma viride) and synthesis of pigments essential for the sporulation (e.g. carotenoids of Neurospora crassa) take place only after the photoinduction.

Taxonomical Significance of Immunologically Active Polysaccharides of $Y$ casts of the Genus Saccharomyces. J. Śandula, A. VoJTková-Lepšínoví, Chemical Institute, Slovak Academy of Sciences, Bratislava.

Mannans or mannose-containing polysaccharides of the cell wall are the main immunologically active components of yeasts. At least 3 types of mannans differing mutually in the structure and immunological activity were found in the yeasts of the genus Saccharomyces. Species of the group Saccharomyces sensu stricto, as Saccharomyces cerevisiae, Saccharomyces bayanus, Saccharomyces italicus, are characterized by branched mannans, the side chains of which contain mannotetraose as the immunodominant group. Species belonging to the group of Torulospora, as Saccharomyces fermentati, Saccharomyces rosei and Saccharomyces delbruckii, have long side chains (penta- and hexamannose) responsible for their immunological activity. Species of the group Zygosaccharomyces, as Saccharomyces bailii, Saccharomyces bisporus and Saccharomyces rouxii, have little branched mannans with short side chains and are immunologically little active. We investigated the immunological relationship between these mannans and antigenic polysaccharides of other genera, e.g. Kluyveromyces, Torulopsis, Hansenula, Candida and Pichia. Saccharomyces chevalieri, the polysaccharide of which has tetramannose-acetylglucosamine as the specific determinant group, is antigenically related with certain species of the genus Kluyveromyces (Kluyveromyces fragilis, Kluyveromyces lactis). Mannans of species of the group Torulospora are structurally and antigenically similar to mannans of species of the group Torulospora are structurally and antigenically similar to mannans of pathogenic yeasts of the genus Candida, species of the group Zygosaccharomyces cross react with yeasts of the genus Pichia. Polysaccharides of yeasts are characteristic in individual species, reflect their mutual relationship and may thus be utilized in taxonomy of the yeasts.

Cytochemical Localization of Catalase in the Yeast Candida boidini 11Bh Oxidizing Methanol. J. VoŘŕšk, O. Volfová, Institute of Microbiology, Czechoslovak Academy of Sciences, Prague.

Catalase (E.C.1.11.1.6) and methanoloxidase (E.C.1.1.3.13) convert methanol to formaldehyde in methanol-oxidizing bacteria and yeasts. In a previous paper (Volfová and Pilát, Folia Microbiol. 19, 249-256, 1974) oxidation of methanol to formaldehyde, $\mathrm{HCOOH}$ and $\mathrm{CO}_{2}$ by the yeast Candida boidinii $11 \mathrm{Bh}$ was investigated and the presence of catalase was demonstrated both in cells and cell-free preparations (iodometric method). On the other hand, the activity of peroxidase (E.C.1.11.1.7was negligible (method with $o$-dianisidine). As data about the cytochemical locali ${ }^{8}$ ) ation of catalase and occurrence of specific organelles, peroxisomes, in yeasts are contradictory (J. Bacteriol. 104, 581-584, 1970; J. Hist. Cyt. 20, 344-349, 1972; Arch. Microbiol. 99, 181-201, 1974). we performed a cytochemical detection of peroxidase activities in intact cells of Candida boidinii $1 \mathrm{iBh}$ using a modification 
of the method with 3,3'-diaminobenzidine (J. Cell. Biol. 38, 1-14, 1968; J. Hist. Cyt. 17, 675-685, 1969). The cytochemical activity of catalase and peroxidase was discriminated by means of $\mathrm{pH}$ optimum (J. Hist. Cyt. 20, 181-191, 1972). It was found that the studied strain of Candida boidinii exhibits the peroxidatic activity and that the activity is localized exclusively in mitochondria. As according to biochemical analyses the activity of peroxidase is negligible and as the detected peroxidase activity is low at $\mathrm{pH} \mathbf{7 . 4}$, catalase localization in mitochondrial cristae is suggested.

Stabitity of the Dicaryotic Phase in Hymenomycetes. K. ZELEN of Antibiotics and Biotransformations, Roztoky near Prague.

The life cycle in hymenomyctes consists of two phases. By fusion of two compatible monocaryotic mycelia the dicaryotic mycelium originates. Under the influence of different treatment (mechanical or chemical) the dicaryotic mycelium can disintegrate into the monocaryotic mycelium during a process designated as dedicaryotization. We followed the disintegration of two dicaryotic and two heterokaryotic cultures of Schizophyllum commune Fr. after the treatment with $\mathrm{CuSO}_{4}$. . $5 \mathrm{H}_{2} \mathrm{O}, \mathrm{Na}_{2} \mathrm{HAsO}_{4} .7 \mathrm{H}_{2} \mathrm{O}$, sodium cholate and cycloheximide. In monocaryotic isolates we tested their compatibility character. At the same time, we followed the degree of inhibition of grow th of both the dicaryotic mycelium and its monocaryotic components in the presence of the used compounds. It was found that the dicaryotic state is spontaneously converted to the monocaryotic one and that the chemical compounds only increase the frequency of this process, whereas the frequency of the occurrence of the monocaryotic isolates, i.e. the effectivity of dedicaryotization, does not depend on differences in sensitivities of monocaryotes. The originating monocaryotes are subsequently selected on the basis of their resistance and sensitivity to a given compound.

On the Problem of Maintenance and Cultivation of Higher Fungi. L. HomoLk A, Research Institute of Antibiotics and Biotransformations, Roztoky near Prague.

When working with higher fungi the problem of maintenance of strains is of utmost importance. The problem may be solved in two basic ways: maintenance of spores or of vegetative material. A culture of the basidiomyceto Oudemansiella mucida producing the antibiotic mucidin is used in this laboratory. As it is rather laborious to obtain basidospores, the culture is maintained in its vegetative form, since the asexual spores are not formed. Several conservation procedures were tested. Attempts to lyophilize the vegetative culture were unsuccessful, on the other hand, storage of the vegetative culture in the presence of dimethylsulfoxide in liquid nitrogen was satisfactory for at least 15 months. The culture preserved its original growth and production ability. Studies concerning assimilation of various nitrogen substrates showed that complex nitrogen substrates must be used in order to reach the optimum growth. The growth rate was followed by measuring the size of colonies on solid media. With the problem of maintenance another problem, viz. heterogenity of the culture, is associated. This latter question can be solved by means of passive selection. Therefore, hyphal fragments were prepared by maceration. These frag- 
ments were then further tested with respect to their production and growth. The culture has a tendency to segregate isolates with a lower growth rate and with a lower activity of production of the antibiotic.

Production of Attractants and Nematicidal Compounds by Predaceous Fungi. J. BALan, P. Nemec, L. Križková, V. Frank, V. Vollek, Biological Institute, Slovak Academy of Sciences and Faculty of Chemical Technology, Slovak Technical University, Bratislava.

Predaceous fungi are microorganisms which capture and kill microscopic nematodes in the soil by means of specialized trapping structures. It was found that predaceous fungi produce compounds attracting nematodes to their proximity. The worms are then mechanically caught and the captured prey is later killed by nematicidal compounds produced by the fungus. The killed nematode is finally used as a source of nutrients. The film shows microinematographic records of different ways of nematode capture by predaceous fungi and various trapping structures. It demonstrates the production of both, attractants and of nematicidal compounds an specially devised methods for the qualitative and quantitative determination of attraction are also explained.

The Acceleration of DNA Synthesis in Cells of Lactobacillus acidophilus by Exogenous Thymine. V. Kuhrová, B. Koukalová, Biophysical Institute, Czechoslovak Academy of Sciences, Brno.

When studying factors regulating replication of DNA in Lactobasillus acidophilus $R_{-}-26$ we also followed the relationship between replication of DNA and concentration of thymine in the growth medium. In these experiments we detrmined: (1) growth rate and DNA content per cell in the presence of increasing concentrations of thymine and (2) DNA synthesis under conditions, when protein and RNA synthesis is inhibited. We found that the growth rate and the average content of DNA per cell in the exponentially growing culture are constant even in the presence of elevated concentrations of thymine $(2.5$ and 10 -fold with respect to the standard concentration) in the growth medium. However, when the synthesis of DNA was followed under conditions, when protein and RNA synthesis was inhibited (amino acid starvation), it could be found that it highly influenced by concentrations of exogenous thymine. In the presence of standard concentrations of thymine $(4 \mu \mathrm{g} / \mathrm{ml})$ the residual DNA synthesis proceeds to the extent corresponding to completion of the started replication cycles of DNA (DNA content increases by $40 \%$ ). In the presence of an increased concentration of thymine (2.5 and 5-fold) and under conditions of amino acids starvation the DNA synthesis is highly stimulated: the DNA content increases by $100 \%$, indicating that new replication cycles are possibly initiated. The obtained results show a possibility that replication of the chromosome can be regulated at the level of precursors. 
Requirements for Protein Synthesis and Sensitivity of Division of Escherichia coli 15 TAU to Temperature Shock During the Cell Cycle. V. Vondress, J. Hanová, M. Lhotsina, L. Hañ́ková, Department of Biophysics, Faculty of Sciences, Charles University, Prague.

It was found in the experiments with the culture of Escherichia coli 15 TAU sy nchronized by arginine and uracil starvation with a subsequent 50 min starvation for thymine that even high concentrations of chloramphenicol $(500 \mu \mathrm{g} / \mathrm{ml})$ or puromycin $(500 \mu \mathrm{g} / \mathrm{ml})$ do not suppress division, provided that they are added later than $40 \mathrm{~min}$ after the addition of arginine and uracil. Roughly during the same interval the division process is sensitive to a short temperature shock $\left(45^{\circ} \mathrm{C}\right)$. As termination of replication is facilitated only after $50 \mathrm{~min}$, when thymine is added, it appears that during termination or immediately afterward, no processes essential for the division (which would require protein synthesis), and no processes sensitive to the temperature shock, take place.

Mapping of the Chromosome of Mycobacterium phlei. J. KoníčEk, M. KoníčKováRadochovi, Institute of Microbiology, Czechoslovak Academy of Sciences, Prague.

Mapping of the chromosome of Mycobacterium phlei is performed by the method of the sequential mutagenesis with $N$-methyl- $N$-nitroso- $N^{\prime}$-nitroguanidine in synchronously dividing populations. The induction of reversions in double auxotrophic mutants (PA met leu, PA met pur, PA met arg, PA met inl, PA met his, PA met pyr, PA leu ser) and induction of mutations resistant to certain antibiotics or chemotherapeutics in single auxotrophic mutants PA met and PA leu was studied with respect to the time of synchronized growth. The maximal induction of mutations can be observed at a time of replication of the studied gene. Construction of the replication map is based on determining the order of replication of genes by means of evaluation of time distances of individual genes from the reference gene (in the present case to methionine or leucine genes) and by evaluation of these distances with respect to replication time of the chromosome. The replication map of 15 genes on the chromosome of Mycobacterium phlei was determined.

Synthesis of DNA, Proteins and Growth of Cells during Cell Cycles of Chlorococcal Algae. J. Dotcha, V. Zachleder, Biotechnological Laboratory, Institute of Microbiology, Czechoslovak Academy of Sciences, Třebcř.

The model of the cell cycle of chlorococcal algae is characterized by the existence of several nuclear cycles during a single cell cycle. Similarly to eucaryotes, each nuclear cycle consists of four phases: GI, S, G2, M plus the phase between division of nuclei and cells. Individual nuclear cycles are switched on, when critical values of RNA, proteins and of volume of cells are reached. When these values are reached the whole nuclear cycle may proceed without a further energy supply. The growth rate determines frequency of the initiation of DNA replication and, thus, also the frequency of cell cycles. The mechanism of regulation incledes elements character- 
istic of procaryotes on one side and eucaryctes on the other. The chloroplast genetic and synthetic material plays also an important regulatory role here. Complex relationships between reproductive and synthetic processes, a mutual influence of simultaneously proceeding phases of the nuclear cycle, different rations of RNA, DNA and protein, as well as the important function of chloroplasts may lead to modifications of the given model in various representative of chlorococcal algae. Their examples will be discussed in the communication.

The Use of Synchronous Populations of Eucaryotic Cells for Studying Biogenesis of Mitochondria. M. GREKsák, K. NEJEDLÝ, Institute of Experimental Veterinary Medicine, Ivanka pri Dunaji, Department of Biochemistry, Faculty of Sciences, Komenský University, Bratislava.

The model of a sequential transcription of chromosomes is so far the best model explaining the discontinuous synthesis of enzymes during the cell cycle. This model in its most explicit form assumes that the order of genes on the chromosome determines the programme of both transcription and following translation during the cell cycle. In this case a certain linear relationship between the time localization of the enzyme synthesis and position of given genes along the chromosome exists. If the principle is of general validity, it may be assumed that it holds true also for the synthesis of enzymes of mitochondrial membranes. This makes it possible to study both the genetic background of nucleocytoplasmic interactions during morphogenesis of mitochondria, as well as regulatory mechanisms determining completion of mitochondrial membranes. This assumption is supported by the finding that mitochondrial respiratory enzymes increase their activities discontinuously and in the same time order, irrespective of whether multiplication of mitochondria or conversion of promitochondria to mitochondria are involved. Due to this fact, synchronous populations of eucaryotic cells appear as the suitable model system for studying mitochondriogenesis.

Biosynthesis of Wall Polysaccharides during the Cell Cycle of Saccharomyces cerevisiae. P. Biely, Chemical Institute, Slovak Academy of Sciences, Bratislava.

The reproductive cycle of the cell wall of Saccharomyces cerevisiae and budding yeasts in general can be divided into three main stages: (1) Budding including initiation of the bud formation, enlargement of the bud and termination of growth of the bud; (2) Division including formation of the primary septum, formation of dividing walls and separation of the daughter and mother cell; (3) Preparation of the daughter cell for the budding, the so-called maturation. The time course of these processes is a function of the growth rate. Hence, it is understandable that contradictory results are presented in papers studying the rate of synthesis of two basic wall polysaccharides, glucan and mannan, during the cell cycle. The present communication evaluates literary data obtained along this line in connection with more recent results obtained by means of quantitative electronmicroscopic autoradiography. 
Regulation of Biosynthesis of Chitin During the Cell Cycle of Saccharomyces cerevisiae. V. Farkaš, Chemical Institute, Slovak Academy of Sciences, Bratislava.

The polysaccharide chitin, poly- $\beta$-1,4-N-acetyl-D-glucosamine, is a specific component of the primary septum formed between the mother and daughter cells during division of budding yeast cells. Formation of chitin in yeasts is limited to a short time interval during the cell cycle; it begins with the occurrence of buds and is terminated by formation of the primary septum. A well defined geometrical shape, simple chemical structure, exact localization in the cell and synthesis during a specific interval of the cell cycle predetermine the yeast primary septum as a suitable model system for morphogenetic studies at the molecular level. It was found when studying in detail properties of the enzyme system of biosynthesis of chitin that the yeast chitin synthetase exists in the cells mostly in a latent, inactive form, localized in the cytoplasmic membrane. During the cell cycle the enzyme is activated by a specific protease, the so-called "activating factor", localized in vesicles of the vacuolar fraction. A thermostable protein, the so-called "inhibitor of the activation factor", localized in the cytoplasm is another component of the system regulating biosynthesis of chitin. This protein binds specifically to the activating factor, thus preventing undesirable activation of the latent chitin synthetase at an incorrect site in the cell.

The presented molecular mechanism of the regulation of morphogenesis found in yeasts may probably have alternatives also in other living organisms.

On the Localization of the Synthesis of Chitin during the Cell Cycle of Saccharomyces cerevisiae. Z. Krátrký, M. VRšanská, P. Biely, Chemical Institute, Slovak Academy of Sciences, Bratislava.

The ability of extracellular enzymes produced by Arthrobacter GJM-1 to dissolve cell walls of Saccharomyces cerevisiae, with the exception of chitin-containing structures, was utilized for a more accurate determination of the interval of the synthesis of chitin during the cell cycle. So far, this question is a subject of extensive discussion in the literature. From the synchronous population of daughter cells of Saccharomyces cerevisiae cell walls were isolated during different stages of development of the bud and treated with the bacterial lytic preparation. The chitin residues obtained after the enzyme hydrolysis of the walls were studied by means of electron microscopy. It was found that the chitin ring, localized at the inner side of the neck connecting the mother cell with the bud, is formed only during growth of the bud. It was not possible to isolate the rings from cells from the stage preceding the budding or from cells in the very early stage of development of the bud. Formation of the primary chitin septum can be considered as the second stage of synthesis of this polysaccharide. However, continuity of synthesis of chitin during the formation of the ring and primary septum cannot be excluded on the basis of the results presented in this communication.

Conjugation of Yeast Protoplasts. A. Sroboda, Department of Biology, Faculty of Medicine, J. E. Purkyně University, Brno.

Protoplasts prepared from haploid yeast, Saccharomyces cerevisiae of different mating types do not exhibit any indications of the mating reaction, both in liquid media 
and on surface of agar films. However, under these conditions, they are able to evoke a specific response, i.e. a blockade of division and formation of protrusions, in intact haploid cells of the opposite sex. Fusion of the protoplast with the cell does not take place here. Conjugation of protoplasts may occur only when protoplasts conclude regeneration of a new cell wall, i.e. after a $8-12 \mathrm{~h}$ cultivation in gelatine or agar gels. The protoplasts can conjugate directly in the gel, or, after isolation of the regenerated protoplasts; in a liquid medium. Morphological studies showed that the conjugation is often incomplete: it is terminated already at the agglutination stage or only a partial fusion of the walls occurs. Under optimal conditions, the frequency of complete conjugations is about $1 \%$. The conjugation of the regeneratad protoplast with the intact cell can also be detected. The conjugating protoplasts contain $1-3$ nuclei. The presented results show that: (1) the cell wall plays an essential role in the onset of the conjugation process; (2) the regenerated cell wall on the surface of protoplasts can modify morphology of the conjugation; (3) the conjugation process in the protoplasts is apparently not strictly limited to a certain phase of the cell cycle, on the contrary to the situation in the cells.

Control of Conjugation during the Cell Cycle of Schizosaccharomyces pombe. E. STRErBLová, Institute of Microbiology, Czechoslovak Academy of Sciences, Prague.

The vegetative cell cycle of Schizosaccharomyces pombe has a long G2 phase extending over a major part of the cell cycle, a short $S$ phase and a very short to indistinct GI phase. The conjugation is preceded by a cell division without DNA synthesis, so that the cells competent to fusion are in the Gl phase of the cell cycle. Morphology of zygotes showed that the cells are capable of fusion during first $3 / 4$ of the cell cycle. This period is identical with the phase of the exponential growth of individual cells of Schizosaccharomyces pombe. Diffusible factors excreted into the medium and controlling the conjugation were not demonstrated in Schizosaccharomyces pombe so far. However, a control mechanism blocking the DNA synthesis prior to the formation of zygotes is assumed. Lengths of the conjugating cells indicate that the cell pairs are not synchronized at a moment of fusion. If caryogamy occurs immediately after the fusion intervals of the Gl phases vary from 0.1 to 0.7 of the cell cycle. The length of the Gl phase can be experimentally varied also during the vegetative cycle of Schizosaccharomyces pombe.

The Effect of the Antibiotic Lomofungin on Yeast Cells and on Symthesis of Wall Components of Protoplasts. M. Kopecká, J. Horák, Department of Biology, Medical Faculty, J. E. Purkyně University, Brno.

The effect of lomofungin, a specific inhibitor of DNA-dependent RNA-polymerase inhibiting synthesis of high molecular RNA. on morphology of yeast cells and grow th and synthesis of wall components of protoplasts was investigat d by means of light and electron microscopy. Lomofungin added to living cells of Schizosaccharomyces versatilis and Saccharomyces cerevisiae inhibits the growth, cell division, formation of zygotes, sporulation of cells, and, in addition, stains red selectively structures localized inside cell nuclei. Concentrations used bring about anomalies of the cell division. Lomofungin at concentrations that suppress completely the cell division 
inhibits the growth of protoplasts of Saccharomyces cerevisiae but does not stop synthesis of the fibrillar wall component of protoplasts. The synthesis of the fibrillar component is not altered even in the case when lomofungin is applied during conversion of cells to protoplasts. The synthesis of the fibrillar component of protoplasts proceeds probably independently of the synthesis of high molecular RNA.

Formation and Growth of Spheroplasts of the Blue-Green Alga Anacystis nidulans. M. Gabriel, Department of Biology, Medical Faculty, J. E. Purkyně University, Brno.

Preparation of protoplasts of blue-green algae, the study of their ultrastructure and viability (growth), regeneration of the wall or reversion are a part of the attempts to acquire the missing link in the spectrum of models utilized in studies of morphogenesis of protoplasts in general. When the rapidly multiplying culture of the bluegreen alga Anacystis nidulans is treated with lysozyme almost $100 \%$ of rod-like cells convert to spherical formations. Studies of the ultrastructure revealed the presence of wall residues on the surface of these formations, thus, spheroplasts are involved here. After the removal of the rigid, probably murein component of the wall, the rest on the surface of these spheroplasts is formed by residues of the plastic layers of the wall. So far, it was not possible to remove the residues of the walls, either with lipase, proteolytic enzymes or with a complex of snail enzymes. The ultrastructure of the wall residues appears as fine membranes, in which further substructures cannot be distinguished. They can be discriminated from the plasma membrane. On ultrathin sections and freeze-etching replicas the wall layer of spheroplasts appears as a narrow zone which is not in contact with the plasma membrane. The chemical character of the wall residues as well as possibilities of their complete removal are further studied. A spherical growth of spheroplasts can be observed in a liquid medium. They grow for a number of days and increase their volume up to 40 -fold. So far, the reversion to the cells could not be demonstrated. A partial regeneration of the wall by organization of the amorphous material proceeds at a submicroscopical level.

Synthesis and Degradation of Murein as Related with the Cell Cycle of Escherichia coli. M. Strna dová, J. Chaloupka, Institute of Microbiology, C'zechoslovak Academy of Sciences, Prague.

During the cell cycle the septum is formed after completion of replication of the chromosome. The formation of the septum is associated with increased synthetic and degradation activities of enzymes metabolizing the cell wall, its rigid component, murein, in the first place. We studied the effect of a substitution of DAP by its analogue on this process. It was found that in the presence of low concentrations of 4-hydroxy-DAP the cells of a DAP-dependent mutant of Escherichia coli extend in length and formation of the septum is simultaneously inhibited. At the same time the activity of an autolytic system results in degradation of murein. When the concentration of the analogue is increased the unfavourable effect is removed and the cells do not differ from the control culture in shape and multiplication, even if their 
growth rate is slightly lower. Thus, the analogue itself does not exhibit an unfavourable effect either on morphogenesis or cell division; however, it is utilized less effectively than DAP.

Replication of the Plasmid DNA in the Cell of Escherichia coli. J. HüÁč́EK, H. Braná, Institute of Microbiology, Czechoslovak Academy of Sciences, Prague.

In a mutant of Escherichia coli we followed the replication of "classical" F-prime elements ( $\mathrm{F}^{\prime} \mathrm{ORF}-1-p r o, l a c$, ade or $\mathrm{F}^{\prime}$-lac) and proximal F-prime elements (type KLF-1 with a different length of the $h s d$-lac region of the bacterial chromosome) by classical means. It was found that after the infection of the cell with $\mathrm{F}^{\prime} \mathrm{ORF}-1$ and $\mathrm{F}^{\prime}-l a c$ fertility functions of the plasmid are expressed normally and the plasmid replicates in the cell in the free state. On the other hand, the KLF-1 proximal plasmids do not persist in the infected cells and "rescue of markers" occurs only by recombination of the $h s d$-lac region of the plasmid with the bacterial chromosome; $F^{-}$heterozygous (duplicated genes) or homozygous haploid recombinants are thus obtained. Introduction of a $\mathrm{rec}_{\mathrm{A}}^{-}$mutation into the bacterial genome makes it completely impossible to detect recombinants after the infection of cells with the KLF-1 plasmid. Due to specificity of this phenomenon for $\mathrm{F}^{\prime}$-proximal plasmids we studied the effect of the change of the genetic structure of the plasmid on its replication. In order to avoid a spontaneous elimination of the plasmid in the donor diploid F-prime cell, which is used for the infection of the followed mutant, the selective medium was adjusted in such a way as to satisfy requirements for amino acids or utilization of a certain sugar by the presence of a given gene on the plasmid. In longer F-prime elements it is then possible to follow segregation of chromosomal genes of the plasmid that are not under selective pressure. It was found in this way that a direct relationship between segregation of the leu gene from the plasmid molecule and replication abilities of the plasmid exists; after the infection of the cell with the F'KLF-1 leu plasmid its fertility functions are expressed normally and the plasmid replicates in the cell. The obtained results indicate that a gene negatively controlling replication of DNA might exist in the leu region of the chromosome of Escherichia coli.

Transformation of Escherichia coli C600 and JCY623 with Deoxyribonucleic Acid of the R1 Plasmid. †M. ŠrogL, Institute of Microbiology, Czechoslovak Academy of Sciences, Prague.

We compared the transforming activity of the plasmid DNA in two recipient strains of Escherichia coli with a different genetic constitution, in order to obtain a biological system for measuring the dose of plasmid and chromosomal genes in the DNA preparation. The R1 plasmid DNA was isolated after lysis of cells of a $6 \mathrm{~h}$ culture of Escherichia coli 1100-R1 drd-19 with lysozyme and Brij-58, followed by incubation with ribonuclease and sodium dodecylsulfate. After a two-fold phenol deproteinization the closed circular DNA was separated by centrifugation in ethidiumbromide and cesium chloride. Strains of Escherichia coli C600 with an unimpared recombination system and the strain JC7623 (recBC sbc), without the ATPdependent deoxyribonuclease, served as recipients. Penetration of DNA inside the 
cells was facilitated by treatment with $0.03 \mathrm{M} \mathrm{CaCl}_{2}$. Resistance to chloramphenicol was determined as the plasmid gene. When using the recipient JC7623 we measured also the activity of the chromosomal gene for the synthesis of histidine. The obtained results indicate that also for plasmid genes carried by the closed circular DNA molecule it is more advantageous to use recipient bacteria lacking the ATP-dependent deoxyribonuclease, as the frequency of transformants is 10 -fold with respect to that in the recipient with a normal recombination system. In addition, in the JC7623 strain it is possible to measure simultaneously also the content of chromosomal genes in the DNA preparation and thus to check purity of the isolated plasmid DNA.

The Study of Early Processes of the Bacterial Transformation in Bacillus subtilis $168 \operatorname{trp}_{2}^{-}$with the Aid of D-Aminomonosaccharides and Chondroitin. P. TrCHÝ, Z. Fuchsová, V. Rytírí, A. Šroglová, Institute of Microbiology, Czechoslovak Academy of Sciences, Prague.

The addition of $\mathrm{D}$-ylucosamine, certain other aminomonosaccharides and the mucopolysaccharide chondroitin to the transformation medium resulted in inhibition of transformation and irreversible binding of DNA in the presence and absence of glucose. D-Glucosamine exhibited its maximal effect at a time of occurrence of irreversible binding of DNA and intervenes most probably with the formation of these receptors, Chondroitin added to precompetent cells in the transformation TM2 medium reacted specifically with precompetent cells only after the formation of receptors of the irreversible binding of DNA. We assume that a specific reaction of chondroitin with the surface of the competent receptor cell is involved. The obtained results indicate that glycoproteins play a role in receptors facilitating the irreversible binding of the donor deoxyribonucleic acid in the transformation and transfection processes.

Isolation of Mutants of Bacillus subtilis $168 \operatorname{trp}_{2}^{-}$with a Changed Transformability. Z. Fuchsová, P. Tichý, Institute of Microbiology, Czechoslovak Academy of Sciences, Prague.

We used Bacillus subtilis $168 \mathrm{tr} p_{2}^{-}$for the isolation of milants with a changed transformability. As a mutagen we used $N$-methyl- $N$-nitroso- $N^{\prime}$-nitroguanidine at a final concentration of $1000 \mu \mathrm{g} / \mathrm{ml}$. Mutants changed in the transformation process were detected by means of replication on a minimal agar medium, the surface of which was sprayed with the donor transformation DNA. The obtained mutants were further tested and divided into three groups according to their transformation abilities: (1) non-transformable mutants; (2) mutants with a decreased transformability; (3) mutants with an increased transformability. Mutants of all groups were tested for their sensitivity to UV radiation, mitomycin $\mathrm{C}$, lysozyme, $\mathrm{SDS}$ and $\mathrm{DOC}$ (deoxycholate). The growth rate in minimal media and the ability to bind irreversibly DNA were also investigated. A possible use of the obtained mutants for analysis of the transformation process is discussed. 
Non-restrictive Mutants in the System of Host specificity of O-Serotypes of Escherichia coli. K. ČejKa, J. HubáčeK, D. Ringrová, Institute of Microbiology, Czechoslovak Academy of Sciences, Prague.

When working with phages designated $a-m$, used in lysotyping of $\mathrm{O}$-serotypes of Escherichia coli we found a new type of host specificity between the strains Escherichia coli $J$ and Escherichia coli 055 . The different number of plaques on both strains indicates that the 055 strain restricts the phage DNA with the host specificity of the $J$ strain. In this system two growth steps of the phage on the new host are required for a fully expressed restriction of the phage DNA. It was possible to isolate the non-restrictive mutants of the 055 strain by means of induction with $N$-methyl$N$-nitroso- $N^{\prime}$-nitroguanidine. According to the qualitative test the non-restrictive mutants obtained in several experiments were further tested for restriction and modification. For this test we used the phage $j$ exhibiting both host specificities ( $J$ and 055 ). On subculture on the original 055 strain the phage of the specificity of the $J$ strain acquires specificity of the new host, whereas on subculture on the isolated nonrestrictive mutants of the 055 strain it retains the specificity of the original $\mathbf{J}$ host. Thus, all $r^{-}$mutants of the 055 strain are simultaneously $m^{-}$. This result differs from those obtained in studies of non-restrictive mutants of Escherichia coli K 12 and B in the fact that during growth of a phage of a given host type on $m^{-}$mutants of the 055 strain the phage is not modified but retains the original host specificity; in Escherichia coli K 12 and B the phage, when grown on $m^{-}$mutants is also not modified, but it simultaneously loses its original specificity.

The Study of Genetic Changes in Pathogenic Mycobacteria. M. ŠLosírek, M. KoníčKova-Radochová, J. Koníček, Institute of Hygiene and Epidemiology, Prague, and Institute of Microbiology, Czechoslovak Academy of Sciences, Prague.

The possible use of mutagenic processes for studying genetic changes was investigated in Mycobacterium bovis BA 38. $N$-Methyl- $N$-nitroso- $N^{\prime}$-nitroguanidine (1000 $\mu g /$ $/ \mathrm{ml}, \mathrm{pH} 6.0,10,30$ and $55 \mathrm{~min}$ treatment resulting in $20,1.5$ and $0.05 \%$ survival) was used for the induction of mutants resistant to isonicotinic acid hydrazide (INH) and thiofen-2-carboxylic acid hydrozide (TCH), mutants producing pigments and mutants with a changed morphology of colonies. Mutagenesis was found to influence mainly resistance markers, whereas changes influencing metabolism of pigments or processes leading to changes in morphology were not induced. Red pigmented colonies were isolated, in which it could be demonstrated that rather a modification than a genetically fixed marker is involved. The frequency of induced mutants resistant to $0.2 \mu \mathrm{g}$ or $1.0 \mu \mathrm{g} \mathbf{I N H} / \mathrm{ml}$ increased by $1-1.5$ order of magnitude as compared with the spontaneous frequency. In the case of the highest concentrations of INH $(5.0 \mu \mathrm{g} / \mathrm{ml})$ and TCH $(50.0 \mu \mathrm{g} / \mathrm{ml})$ the frequency of resistant mutants did not increase above the spontaneous values. Morphology of colonies varied according to age of the culture. In younger cultures of Mycobaclerium bovis BA 38 typical convex colonies of the $\mathrm{S}$ phase were observed, a tendency to the $\mathrm{R}$ phase could be demonstrated in older cultures.

Do Colicins E2 and E3 Influence Blue-Green Algae? J. ŠMarda, D. Valová, Department of Biology, Medical Faculty, J. E. Purkyně University, Brno. 
Young cultures of the blue-green alga Anacystis nidulans and others were exposed to colicins $\mathrm{E} 2$ or $\mathrm{E} 3$ at $37^{\circ} \mathrm{C}$; they were then washed with water, suspended in liquid Bold's medium and incubated together with control cultures, at $25^{\circ} \mathrm{C}$ for 4 weeks under regular illumination. Absorbency (at $630 \mathrm{~nm}$ ) was measured and cells were counted at $2-3$ day intervals. Both colicins exhibit a pronounced effect in the crude state, in a cultivation medium of producing strains. Cultures of Anacystis nidulans exposed to the above colicins grow at the same rate as control ones just for $1-3$ days; later their growth rate is decreased and till about 9 days the absorbancy as well as well as the number of cells decrease to the original values or even below them. Synthesis of assimilation pigments is impaired already after $2-4$ days, when carotenoids and chlorophylla disappear from the cells. After 4-8 days the culture becomes distinctly blue, as the cell content of phycocyanine decreases more slowly; however, after 9 days this latter pigment disappears from the cells as well. Beginning with the 10th day of cultivation two possibilities may occur: (a) the experimental culture does not change any further, if the original number of cells is low (providing that autolysis does not occur); (b) if the initial number of cells is higher, the depigmented ones begin to multiply again (most likely due to photoassimilation of organic carbon), reaching the growth rate of control cells after about 12 days. Purified colicins have only a negligible inhibitory effect. On the other hand, the cultivation medium of colicin indicator strains, generally considered as non-colicinogenic, exerts pronounced inhibitive effects. It thus appears that the synthesis of assimilation pigments in thyalkoids of blue-green algae is not blocked by colicins but rather by another thermolabile product of metabolism of intestinal rod-shaped bacteria.

Some Characteristics of the Aerobic Respiratory Chain of Citrobacter freundii. J. KADĚrová, F. KAPRÁleK, Department of Genetics, Microbiology and Biophysics, Faculty of Sciences, Charles University, Prague.

Citrobacter was cultivated aerobically on a medium with galactose. Cells from the exponential phase were mechanically disintegrated, the cell-free extract was centrifuged at $140000 \mathrm{~g}$, the sediment was resuspended, centrifuged again and membrane fragments were resuspended in $0.05 \mathrm{M}$ Tris buffer $\mathrm{pH} 7.8$. Their ability to oxidize formiate, succinate, lactate and glycerophosphate with oxygen, dichlorophenolindophenol (DPIP), phenazinemethosulfate + oxygen (PMS $+\mathrm{O}_{2}$ ) and ferricyanide as final electron acceptors was investigated. None of four dehydrogenases could reduce ferricyanide. Remaining electron acceptors were effective. Destruction of quinones by irradiation at $360 \mathrm{~nm}$ resulted in the inhibition of transport of electrons from formiate, succinate and glycerophosphate to oxygen and DPIP; transport to PMS $+\mathrm{O}_{2}$ was not influenced. Oxidation of lactate with oxygen, DPIP and PMS $+\mathrm{O}_{2}$ was insensitive to the destruction of quinones. Transport of electrons from all 4 substrates to oxygen was inhibited by 2 -heptyl-4-hydroxy-quinoline- $N$-oxide (HOQNO). In the case of DPIP the HOQNO was ineffective being stimulatory in the case of PMS $+\mathrm{O}_{2}$. The following can be deduced on the basis of the results obtained: the electron transport from formiate, succinate, glycerophosphate and lactate to oxygen includes cytochrome $b$ and, with the exception of lactate, also quinones. Cytochrome $b$ is not involved in the transport of electrons from the substrates to DPIP, however, with the exception of lactate, quinones function here. Neither quinones nor cytochrome $b$ play a role in the transport of electrons from the substrates to PMS and PMS thus reacts directly with primary dehydrogenases. 
Characterization of the Solubilized and Membrane-Bound ATPase of Citrobacte: freundii. A. Ontrová, F. Kaprálek, Department of Microbiology, Faculty of Sciences, Charles University, Prague.

Exponentially growing aerobic cells were disintegrated with ballotini and the membrane-containing fraction was obtained by centrifugation. The solubilized and membrane-bound forms of ATP-ase (EC 3.6.1.3) were obtained by solubilization of membranes in a buffer with low ionic strength $(1 \mathrm{~mm}$ Tris-HCl, $\mathrm{pH} 7.5$ with $1 \mathrm{~mm}$ $\mathrm{MgCl}_{2}$ ) and centrifugation at $170000 \mathrm{~g}$ for $90 \mathrm{~min}$. Properties of the two forms of the enzyme were compared. The activity of both the solubilized and membranebound ATP-ase depends on the presence of $\mathrm{Mg}$ ions. The optimal ratio $\mathrm{Mg} / \mathrm{ATP}$ equals to $1: 1$ and $1: 2$ for the solubilized and enzyme-bound enzyme, respectively. The activity of the solubilized ATP-ase increases within the $\mathrm{pH}$ range of $5-9$; whereas the membrane-bound ATP-ase has a sharp optimum at pH 7 . The temperature optimum of the solubilized ATP-ase is $50^{\circ} \mathrm{C}$, that of the membrane-bound enzyme is $55^{\circ} \mathrm{C}$. The activation energies equal $65.5 \mathrm{~kJ}$ and $8.8 \mathrm{~kJ}$ in the solubilized ATP-ase and the membrane-bound enzyme, respectively. $K_{M}$ for ATP as substrate was found to be $2.4 \mathrm{~mm}$ for both types of the enzyme. ADP inhibits competitively the membrane-bound ATP-ase with a $K_{i}$ of $1.1 \mathrm{~mm}$. Hydrolysis of ATP is inhibited by $\mathrm{NaN}_{3}$, both in the case of the solubilized and membrane-bound ATP-ase. KCN did not influence either form of ATP-ase. The solubilized ATP-ase was practically insensitive to $1 \mathrm{~mm} 2,4-\mathrm{DNP}$, the membrane-bound enzyme was inhibited to $50 \%$ activity. Gel filtration on Sepharose $6 \mathrm{~B}$ was used for the determination of molecular weight. Two peaks with the ATP-ase activity were demontrated and their molecular weight was determined as $3.1 \times 10^{5}$ and $4.2 \times 10^{5}$.

The Electron Transport System Reducing Tetrathionate in the Membrane of Citrobacter freundii. ¿̌. Novotńx, F. Kaprálek, Department of Genetics, Nicrobiology and Biophysics, Faculty of Sciences, Charles University, Prague.

Cells of the exponential culture of Citrobacter freundii growing in the presence of tetrationate in a complex medium with galactose at $30^{\circ} \mathrm{C}$ were mechanically disintegrated and the membrane fraction was prepared as the washed sediment by centrifugation of the cell-free extract at $170000 \mathrm{~g}$. When investigating the ability of the membrane fraction to reduce tetrathionate in the presence of different physiological donors of hydrogen and electrons and their combinations, it was found that the most effective substrates in the respiration of tetrathionate are formiate, $\mathrm{NAD} \mathrm{H}_{2}$ and glycerophosphate and that the transfer of electrons to tetrathionate by a terminal reductase is apparently not the limiting step in the reaction sequence. The transport of electrons from formiate, $\mathrm{NADH}_{2}$ and glycerophosphate to tetrathio nate is inhibited effectively by 2-heptyl-4-hydroxy quinoline- $N$-oxide and antimycin $\mathrm{A}$, indicating that cytochrome $b$ is involved in this reaction sequence; this conclusion is supported by spectrophotometric demonstration of reoxidation of the raduced cytochrome $b$ by tetrathionate. Amytal and rotenone inhibited the redustion of tetrathionate by the above-mentioned substrates less effectively, KCN and $\mathrm{NaN}_{3}$ were effective inhibitors in the case of formiate. The ability of the membrane fra ction to transfer electrons to tetrathionate was considerably decreased after destruction of quinones by irradiation at $360 \mathrm{~nm}$, the activity was partially restored after the addition of vitamin $\mathrm{K}_{3}$. On the basis of the obtained results it can be deduced that quinones play a role in the transfer of electrons to tetrathionate. 
The Effect of New SH-Reagents on Protein Symthesis in a Cell-free System of Escherichia coli. O. Ondrejičková, L. Drobnica, Department of Technical Microbiology and Biochemistry, Faculty of Chemical Technology, Slovak Technical University, Bratislava.

Of the studied SH-reagents 2,3-dicyano-1,4-dithiaanthraquinone, quaiazulene, $p$-bromobenzylisothiocyanate, ethyl ester of 2-isothiocyanate-3-methyl-butyric acid, $N$-trichloromethyl-thiotetrahydrophthalimide and $N, N$-dimethyl- $N^{\prime}$-phenyl-( $N$-fluorodichloromethylthio)-sulphamide exhibited a pronounced inhibitory effect on the poly $(\mathrm{U})$ directed synthesis of polyphenylalanine. The compounds inactivated the S 100 supernatant fraction. When studying the effect of SH-reagents on ribosomes it was found that ethyl est 3 r of 2-isothiocyanate-3-methylbutyric acid and mainly $p$-bromobenzylisothiocyanate are highly inhibitory. When investigating the effect of $p$-bromobenzylisothiocyanate on the activity of peptidyltransferase measured in the presence of puromycin it could be demonstrated that the compound does not inhibit the enzymic activity. All studied compounds functioned as inhibitors of the elongation factor EF-G. From this point of view 2,3-dicyano-1,4-dithiaanthraquinone was most effective. Most studied compounds are new $\mathrm{SH}$-reagents differing in their physico-chemical properties and chemical reactivity from model SH-compounds. The results indicate that isothiocyanates can be utilized in studies of the mechanism of protein synthesis, particularly of the function of SH-groups of ribosomes and individual enzymes or factor required for protein synthesis.

Catabolite Repression of Synthesis of Penicillinamidohydrolase in Escherichia coli. V. VoJTíškk, Research Institute of Antibiotics and Biotransformations, Roztoky near Prague.

Synthesis of penicillinamidohydrolase (EC 3.5.1.11 - penicillinacylase) in $E s$ cherichia coli is subject to the absolute catabolite repression by glucose and partial repression by acetate. The absolute repression by glucose and partial repression of the enzyme synthesis by acetate is considerably influenced by cyclic $3^{\prime}, 5^{\prime}$-adenosine monophosphate (cAMP). The growth diauxy in a mixed medium glucose + phenylacetic acid serving as sources of carbon and energy is removed by the addition of CAMP. CAMP does not influence the basal rate of the enzyme synthesis (without the inducer). Derepression of the enzyme synthesis by cAMP in a medium with glucose and the inducer is associated with utilization of the inducer by derepression of other enzymes responsible for degradation of phenylacetic acid. Lactate is a "catabolimlly neutral" carbon source suitable for the maximal production of the enzyme. Natur (f) the induction of the enzyme in Escherichia coli is gratuitous. In a medium with lictate as a carbon and energy source the gratuitous induction of the enzyme synthesis by phenylacetic acid is not influenced by cAMP; however, cAMP fully overcomes the otherwise absolute catabolite repression of the synthesis of this enzyme by glucose. Mutants fully resistant to the partial repression by acetate, resistant to repression by glucose and insensitive to the effect of cAMP were isolated. 
The Effect of Isothiocyanates on the Protein-synthesizing Apparatus of Bacteria. Reaction of 4-Bromophenylisothiocyanate- ${ }^{35} \mathrm{~S}$ with $A$ minoacyl-tRNA of Escherichia coli in vivo. J. Augustín, L. Drobnica, P. Nemec, Department of Technical Microbiology and Biochemistry, Faculty of Chemical Technology, Slovak Technical University, Bratislava.

When studying the topographical distribution of 4-bromophenylisothiocyanate-35S in a logarithmically growing culture of Escherichia coli it was possible to determine a portion of the total quantity of isothiocyanate chemically bound to cell components, which is incorporated also into the tRNA fraction, isolated by means of phenolic deproteinization and deprived of $\mathrm{rRNA}$. The subsequent purification of the preparation on DEAE-cellulose and Sephadex G-200 columns showed that a chemically bound radioactivity is involved. The radioactivity could be solubilized by treating the tRNA precipitate with $5 \%$ trichloroacetic acid in the cold or by a mild alkaline hydrolysis in a buffer $\mathrm{pH} 10$. Within the $\mathrm{pH}$ range from 6 to 11 and temperatures $20-60^{\circ} \mathrm{C}$ it was not possible to demonstrate the reaction of 4 -bromophenylisothiocyanate-35S with preparations of aminoacyl tRNA deprived of the bound amino acid by means of alkaline hydrolysis. It follows that under the given conditions isothiocyanate does not react with minorite bases of -tRNA. Thus, a reaction of isothiocyanate with the free amino group of the aminoacyl-tRNA is involved here. As compared with respective free amino acids occurring in the cell the amino group of the aminoacyl-tRNA has a $p K_{a}$ value lower by as much as two units, reacting with isothiocyanates also at neutral $\mathrm{pH}$. In spite of the above finding, the inactivation of enzymes with essential thiol groups could be considered as the main point of the inhibitory effect of isothiocyanates. The above mentioned reaction with the aminoacyl-tRNA may cause only a temporary and partial inhibition of protein synthesis, due to a decrease of the concentration of aminoacyl-tRNA with a free amino group.

L-Asparaginase in BCG Strains. S. Štrbáx̌ová-Nečinová, M. Mára, J. Gallová, Institute of Medical Microbiology and Immunology, Medical Faculty, Charles University, Prague and Institute of Hygiene and Epidemiology, Prague.

During the last decade the bacterial L-asparaginase attracted a considerable attention because of its antitumor activity. The enzymic activity was demonstrated. in a number of bacteria, in Escherichia coli, Serratia marcescens etc. and recently also in certain strains of BCG. Two isoenzymes of two different $\mathrm{pH}$ optima, out of which only one, EC-2 L-asparaginase, has the antitumour activity, were demonstrated in Escherichia coli. The experiments referred to here concentrated on the comparison of the L-asparaginase activity in different BCG strains, determination of the $\mathrm{pH}$ optimum, dependence of the enzyme production on cultivation conditions and localization of the enzyme in the cells. In most studied strains we observed two activity optima, i.e. at $\mathrm{pH} 5.4$ and 8.0. A peak at $\mathrm{pH} 6.6$ could sometimes be observed. The highest production of L-asparaginase was determined in the Japanese and Bulgarian BCG vaccine strains; Danish, Czechoslovak and French strains are weaker producers, Moscow and Glaxo strains did not produce L-asparaginase. On the classical Sauton medium (SAS) containing asparagine as the only nitrogen source the Czechoslovak strain produces more than two-fold of $\mathrm{L}_{\mathrm{L}}$-asparaginase than in the production me- 
dium, in which asparagine is replaced with caseine hydrolysate (SH). It may be assumed on the basis of preliminary experiments that the major portion of the enzymic activity is localized in the cytoplasm.

Production of the Antibiotic and Exoprotease in Sporulation Mutants of Bacillus licheniformis. F. Palečková, Research Institute of Antibiotios and Biotransformations, Roztoky near Prague.

Non-sporulating and oligosporogenic mutants were isolated in three strains of Bacillus licheniformis producing bacitracin at the production level and in one collection strain Bacillus licheniformis CCM 2182 in experiments with ethylmethanesulfonate (production strains) and acriflavine (collection strain). Strains with a genetic block at the beginning of sporulation, characterized by a zero or reduced production of the antibiotic and exoprotease, were isolated representing 12 and $20 \%$ in the production and collection strains, respectively. Other strains were blocked at later stages of the sporulation and their production of the antibiotic and exoprotease was not changed or only insignificantly increased.

The Origin and Morphology of Non-mycelial Forms in Streptomycetes. J. S̆ŤAsTNÁ, J. Ćáslavská, Institute of Microbiology, Czechoslovak Academy of Sciences, Prague.

Under submerged cultivation, which makes a rich growth (medium with beef extract) of the culture possible, Streptomyces granaticolor grows as abundantly branched hyphae. In a medium containing only amino acids and bases of nucleic acids these actinomycetes grow under certain physico-chemical conditions in the form of swollen ellipsoid to spherical formations. We called them non-mycelial forms. The size of these forms varies considerably. Electron microscopy showed that the cells divide irregularly and the septation is atypical, e.g. in the cass of large round formations the septa are localized near poles of the cell. From the spherical forms short hyphae often protrude and change again to spheres at their termini. A membraneous system differing from mesosomes of filamentous cells can be observed inside the non-mycelial forms. On transfer to the medium supporting the filamentous growth the spherical cells are reversed to filaments and, on the contrary, the filaments transferred to the medium with amino acids begin to form non-mycelial forms.

The Effect of Dodecylpiperidine-N-oxide on the Bacterial Cell. D. Mrynarč́x, D. Georch, V. Cupková, P. Hodál, P. Blanárik, Pharmaceutical Faculty, Comenius University, Bratislava.

Dodecylpiperidine- $N$-oxide (DPNO), one of the most effective antimicrobial amine- $N$-oxides, is bacteriostatic and on longer contact also bactericidal mainly to Gram-positive bacteria. Gram-negative bacteria are less influenced. The compound damages the cell surface, as demonstrated by release of the intracellular material, and brings about also lysis of protoplasts of Bacillus megaterium and spheroplasts of Escherichia coli. At higher concentrations it lyzes also the isolated cell walls and even whole cells. A resistant strain of Escherichia coli tolerating up to $34000 \mu \mathrm{g} / \mathrm{ml}$ 
was isolated by cultivating the bacteria in the presence of increasing concentrations of the compound. This strain differs from the original sensitive strain in morphology and in some other properties.

\section{APPLIED MICROBIOLOGY}

Production of Lysine by Amino Acid-Sensitive Mutants. J. Prachý, Resaarch Institute of Antibioties and Biotransformations, Roztoky.

During the search for mutants exhibiting high lysine production, attention was centered on mutants whose growth in a minimal medium is inhibited in the presence of amino acids. The parent organism was the prototrophic strain of Corynebacterium sp. 9366. Mutants were induced by a prolonged action of ethyl methanesulphonate. The effort to isolat mutants sensitive to threonine, methionine and threonine + + methionine yielded mutants sensitive to the two amino acids but not mutants sensitive to their combination. The mutants were subjectad to a production appraisa as to their ability to accumulate lysine in the medium. The most favourable results were obtained with the mutant Corynebacterium sp. $9366-\mathrm{T} / 6$; its growth in a minimal medium was inhibited by threonine at very low concentrations and it accumulated relatively large amounts of lysine in the medium. The effect of various amino acids on the growth of the mutant was tested, suitable medium composition for its cultivation was determined and optimum cultivation conditions were defined. A comparison of the production of lysine by the mutant with production attained by conventionally used strains showed that the production of this amino acid by the mutant Corynebacterium sp. 9366-T/6 (prototrophic organism sensitive to throenine) equals that attained by the traditional strains.

Bacitracin Biosynthesis in Sporulating and Asporogenic Strains of Bacillus licheniformis. F. SHÉkAL, Research Institute of Antibioties and Biotransformations, Roztoky.

The course of bacitracin synthesis in the two groups of bacilli depends on differences in their primary metabolism. The rate of utilization of carbon and nitrogen sources regulates the biosynthesis of bacitracin synthetase and other secondary metabolites, e.g. extracellular enzymes. The production of bacitracin in sporulating strains is in the range of $290-360 \mathrm{units} / \mathrm{ml}$ after $36 \mathrm{~h}$ of fermentation while asporogenic mutants reach, under the same conditions, a production of $430-460$ units $/ \mathrm{ml}$. Pantothenic acid and beta-alanine stimulate further the biosynthesis of the antibiotic, enhancing its production in asporogenic mutants to $480-510 \mathrm{units} / \mathrm{ml}$ medium. The stimulatory effect of the two substances was proved in both high- and low-production strains of Bacillus licheniformis. Experimental data point at a physiological function of pantothenic acid in the protein-template mechanism of bacitracin biosynthesis. 
Improvement of the Production Strain of Penicillium chrysogenum and Definition of Optimum for the Biosynthesis of Penicillin $V$ and $G$. E. Welwardová, M. Bučko, Biotika, Slovenská Lupča.

Active and passive selection afforded a total of 16,000 isolates which were then evaluated in terms of their production and morphological changes. In a preliminary test, the isolates were selected according to the results of a submerged cultivation, the antibiotics production being assayed by the biological disc method. The improvement of the production strain was carried out using both literary techniques and methods conventionally used in our laboratory. Individual mutagenic treatments were evaluated according to the production variation curves of the resulting isolates and the percentage of surviving and morphological mutants. The most promising isolates were tested on a semi-pilot and pilot scale. The number of isolates tested on this level was 25,6 production strains were used in full-scale production. The significance of the difference between the production rates of two strains was appraised by the $t$-test. The elaboration of optimum production conditions for the 6 production isolates resulted in a $150 \%$ increase of the antibiotics production in a full-scale technological process.

Simultaneous Induction of Beta-Galactosidase and Tryptophanase in Escherichia coli. E. Stejskalová, B. Sikyta, E. Pavlasová, Institute of Microbiology, Czechoslovak Academy of Sciences, Prague.

The possibility of induction of two enzymes (beta-galactosidase and tryptophanase) by methyl-beta-D-thiogalactopyranoside and tryptophan in several Escherichia coli strains in a synthetic medium was studied. The data showed that during the simultaneous induction of both enzymes the synthesis of tryptophanase was always expressively suppressed while the inducible synthesis of beta-galactosidase remained unchanged. In several strains, however, the simultaneous induction of the two enzymes brought about a slight reduction in the synthesis of the latter enzyme.

Properties of Escherichia coli Mutants with High Content of Beta-Galactosidase. E. Pavlasová, B. Sikyta, E. Stejskalová, Institute of Microbiology, Czechoslovak Academy of Sciences, Prague.

Hyperproducible mutants of Escherichia coli synthetizing constitutively betagalactosidase were obtained by selection in a chemostat under the lactose limitation of growth. These mutants produced 10-15-fold quantities of the enzyme as compared to fully induced parent strain. In contrast to typical constitutive mutants most hyper-strains exhibited a rise in the specific enzyme activity with proceeding growth of the culture, with a maximum at the end of the logarithmic growth phase. On inducing another enzyme (tryptophanase) in these hyper-mutants by tryptophan the level of beta-galactosidase was lowered, returning to the original value after the removal of the inducer. These experiments were performed in a chemostat under lactose limitation and with a continous feed of the inducer for tryptophanase. 
Stoichiometric Model of Yeast Growth on Methanol. P. Pilát, A. Prokop, J. VoTRUBA, Institute of Microbiology, Czechoslovak Academy of Sciences, Prague.

The results are reviewed of the study of growth kinetics of Candida boidinii $11 \mathrm{Bh}$ on methanol. Growth and oxidation studies showed that even at relatively low concentrations of substrates the growth and respiration are inhibited. Analysis of oxidative products of methanol, i.e. formaldehyde and formic acid during the growth in a batch culture and separate experiments on model mixtures (methanol-formaldehyde, methanol-formic acid) revealed that formic acid can be responsible for the actual inhibition of the process since its accumulation is proportional to initial methanol concentration. On the other hand, formaldehyde concentration is maintained at a non-inhibitory level owing to its preferential incorporation in cellular components. Only at higher methanol concentrations the excess formaldehyde is oxidized to formic acid, causing a lower biomass yield. A kinetic scheme was designed for the grwoth of yeast on methanol, in which formaldehyde is considered as a substrate and formic acid as an inhibitor. A set of first-order differential equations describing the scheme was numerically integrated using a computer. The resulting rate constants and parameters were compared with experimental values.

Methanol-Oxidizing Enzymes. O. VoLfová, Instituté of Microbiology, Czechoslovak Academy of Sciences, Prague.

Cell-free tract prepared from the cells of the yeast Candida boidinii 11 Bh grown on a mineral medium with methanol oxidized, apart from methanol, also other low-molecular alcohols. The length of the carbon chain and the position of the $\mathrm{OH}$-group were shown to affect significantly the oxidation of alcohol molecule. Methanol oxidation proceeded only in the presence of molecular oxygen, yielding formaldehyde as a product. Optimum conditions for the oxidation were $\mathrm{pH} 8.5$, temperature of $35^{\circ} \mathrm{C}$; the $K_{\mathrm{m}}$ for methanol was $0.8 \mathrm{~mm}$. The activity of alcoholoxidase, i.e. the enzyme catalyzing the oxidation of methanol to formaldehyde, was not inhibited by $1 \mathrm{~mm}$ KCN, EDTA, or iodoacetic acid. The most potent inhibitor was $p$-chloromercuribenzoate. The cell-free extract contained also active catalase which participated in methanol oxidation, NAD-formaldehyde dehydrogenase whose activity depended on the presence of reduced glutathione ( $K_{\mathrm{m}}$ for formaldehyde 0.29 ), and $\mathrm{NAD}$-formate dehydrogenase ( $K_{\mathrm{m}}$ for formate $\left.55 \mathrm{~mm}\right)$.

Application of Optimization Methods in the Search for Optimum Composition of Microbiological Media. J. Votruba, P. Pllát, O. Ksandrová, P. Doberský, A. Prokop, Institute of Microbiology, Czechoslovak Academy of Sciences, Prague.

A survey is given of experiment design methods, especially gradient method of Box-Wilson and the direct search method of Hook-Jeeves in Rosenbrock's modification. The methods can be used in the optimization of medium composition using arbitrary optimization criterion, e.g. the formation of biomass or product in a certain time period. The criterion can also include economical aspects such as raw material price or operating costs. The procedures were compared with respect to their laboriousness and time demands of the experiments. The direct search method was 
found to be more suitable for multi-variable optimization. These conclusions are illustrated on the growth of yeast on methanol; the optimization criteria were the growth rate, the time necessary to achieve a certain growth, and the growth attained in a certain time interval. Optimization procedure included 5 medium com ponents.

Effect of Oxygen Supply on the Behaviour of Facultatively Anacrobic Bacteria in Steady States of Continuous Cultivations Performed in a Multistage Tower Fermentor. J. PÁca, V. Grégr, M. Rychtera, Institute of Chemical Technology, Department of Fermentation Chemistry and Technology, Prague.

Cultivations were carried out in a multistage tower fermentor with perforated plates and mechanical mixing in each stage. Fermentor consisted of 4 reaction steps and an overflow stage with foam collector. The fermentor was operated using a cocurrent-flow arrangement for nutrient medium and air. Prior to actual cultivations the hydrodynamic behaviour and oxygen transfer were tested for the type of plates used. The oxygen transfer was determined using the sulphite method and oxygen supply was controlled by changing the stirrer speed and air flow rate. The organism used was Klebsiella aerogenes CCM 2318 growing on a minimum glucose medium at constant $\mathrm{pH} 7.0$ and dilution rates of 0.178 and $0.6 \mathrm{~h}^{-1}$. The separating effect of the plates was perceptible in concentration gradients of cell dry weight and residual sugar and, under certain conditions, also in marked differences in respiration and $\mathrm{CO}_{2}$ formation between reaction stages 1 and 4 . This signifies a different physiological state of the culture in different stages. Limitation of oxygen supply affected the metabolism of the culture which was reflected in quantitative changes in tota production of acid products, production of volatile arids, ethanol, and in yield. The alteration of oxygen supply brought about also a change in respiration quotient.

Bioengineering Study of Erythromycin Fermentation in a Pilot-Plant Fermentor. P. Ettler, J. Páca, Research Institute of Antibiotios and Bio-Transformations, Roztoky, and Institute of Chemical Technology, Department of Fermentation Chemistry and Technology, Prague.

A pilot-plant fermentor Chemap 300 was used for a study of hydrodynamic behaviour of model modia with viscosities corresponding to those of suspension fermentation media. The value of volume oxygen transfer coefficient $K_{\mathbf{L}}$ a, which depends on impeller speed, aeration rate and physicochemical properties of the medium, was determined in the medium prior to inoculation by a static method; gassing-out during cultivation experiments, it was determined by a dynamic method gassing-out using a membrane sterilizable electrode and the measuring system Sensorlabs IL 530. The resulting values of $K_{\mathrm{L}} a$, aeration criterion $\mathrm{Na}$, and power characteristics $P_{\mathrm{g}}, P_{\mathrm{o}}$ can be used for the scaling-up to a plant scale as well as for the design and realization of biological experiments in the fermentor itself. The experimental data on erythromycin fermentations document the effect of varying impeller speed and aration rate on the growth of Streptomyces erythreus and the formation of the secondary metabolite. The reguletion of individual variables, aimed at the elimination of mechanical damage to the mycelium, indicates the possibilities of optimization of the process. 
Ionizing Radiation and Sterilization Techniques. V. Horáková, D. Sladká, State Textile Research Institute, Department of Research and Application of Ionizing Radiation, Brno-Veverská Bítýška.

The fifties mark the beginning of the application of ionizing radiation for the sterilization of medical instruments, preparations and biological tissues on an industrial scale. The main radiation sources are electron accelerators and isotopes ${ }^{60} \mathrm{Co}$ and ${ }^{137} \mathrm{Cs}$. An industrial-scale sterilization plant is described using ${ }^{60} \mathrm{Co}$. Radiation sterilization has certain advantages over other methods; it is accomplished at normal temperatures and its efficiency is independent of the heat conductivity of objects, ambient pressure and humidity; the penetrating power of the radiation makes it possible to sterilize objects even after their air-tight sealing into packaging materials; the sterilization is uniform in all layers of the given material; no toxic residue are left to adhere to the surface; the sterilization is continuous. Radiation steriiization is suitably used with plastic medical instruments, instruments from thermolabile natural materials, bandages, some pharmaceutical preparations and biological tissues. Special methods are used in the preservation of foodstuffs. The minimum sterilization dose depends on the counts and resistance of contaminating microorganisms and the subsequent fate of sterilized objects. Disposable medical instruments are usually sterilized by a minimal dose of $25 \mathrm{~kJ} / \mathrm{kg}$. The efficiency of sterilization device is controlled by physico-chemical dosimetric methods combined with the determination of inactivation curves of resistant standard bacterial and viral strains. The majority of microorganisms $(99 \%)$ display a lowering of the initial counts by $8 \log$ eycles upon irradiation by low doses up to $15 \mathrm{~kJ} / \mathrm{kg}$. Resistant forms were found among some species of the genera Micrococcus, Streptococcus, Corynebacterium and Bacillus and among viruses, especially those smaller than $20 \mathrm{~nm}$. The reliability of radiation sterilization with respect to the possible survival of microorganisms is discussed.

Alkylphenol Antioxidants as Stabilizers of Defoamers Used in Fermentations. L. WELwaRd, J. Rakyta, Drug Research Institute, Hlohovec, Branch Slovenská Lupča.

Defoamers of plant (soybean, sunflower, rape-seed oils) and animal origin (pork fat, tallow) undergo a gradual oxidation depending on storage conditions. The process leads to the formation of secondary products unfavourable for fermentative processes. The decrease in production activity due to the presence of these compounds may amount in some cases, e.g. during chlorotetracycline biosynthesis, to $80 \%$. The application of antioxidants brought about the suppression of the oxidative decomposition of the defoamers and the formation of toxic products during storage and heat sterilization. The antioxidants themselves did not affect negatively the production activity of the strains under study. Several analytical methods, e.g. the Kreis's test, were modified to permit the quantitative determination of the effect of oxidation on the defoamers in question.

Utilization of Carbon Sources During Penicillin Biosynthesis. V. Matelová, Research Institute of Antibiotics and Biotransformation, Roztoky.

One of the principal factors affecting the yield of fermentation process during biosynthetic penicillin production is the composition of the nutrient medium, in 
particular the source of assimilated carbon. Its type, accessibility and price define also for the most part the economic aspects of the production. The type and concentration of the carbon source may be used for controlling the rate and yield of the fermentation. If the source is a slowly assimilated disaccharide such as lactose, its total amount can be present in the medium already at the onset of fermentation; a suitable combination with sucrose can provide a remarkable increase in fermentation yields. On the other hand, easily fermented carbon sources such as sucrose have to be added in controlled amounts during the fermentation to ensure optimum conditions for the formation of both biomass and penicillin. Biomass production increases with running rising concentration of sucrose added. Utilizability of sucrose is determined by its concentration in the medium, the most complete assimilation being found at low concentration of the sunstrate. To make the biosynthetic penicillin production more economical, the traditional carbon sources were replaced by ethanol, with satisfactory results.

Optimum Conditions for the Ultrafiltration of Some Proteins. J. Haxcs, H. SkaChová, A. PašeK, Food Research Institute, Prague.

Specific property of ultrafiltration membranes, viz. the ability to preclude or permit the passage of substances of higher or lower molecular weight, was used to investigate the behaviour of some proteins (cytochrome $c$, chymotrypsinogen, serum albumin) using the ultrafiltration device AMICON, model 202. The most suitable membranes for the purpose were PM 10, PM 30, UM 10. Using these membranes, the efficiency of ultrafiltration, effect of pressure on flow rate and effect of concentration of concentrated protein on retention were studied. The results were used in the separation of technologically significant enzymes, expecially cellulases.

Kinetics of Starch Splitting by Immobilized Amyloglucosidase. J. Kučera, J. Hanus, Food Research Institute, Prague.

Mould amyloglucosidase (NOVO) was immobilized on a carboxymethylcellulose gel using a procedure described earlier. The free carboxyl groups of the gel affected in a characteristic manner the optimum $\mathrm{H}$ of the immobilized enzyme. On the other hand, the retarding effects of diffusion on the course of enzyme reaction were relatively small. Examination of the dependence of reaction rate on substrate concentration yielded the value of apparant $K_{\mathrm{m}}$; the ratio of $K_{\mathrm{m}}$ of soluble enzyme and the apparent $K_{\mathrm{m}}$ of immobilized enzyme defined the partition ratio for the substrate between the liquid and the carrier phase. The latter was found to contain a higher concentration of substrate than the former. The results were compared with corresponding data for other carriers. The study of reaction rate as dependent on the mean polymerization degree of soluble starch DP $28-4$ showed that, with soluble enzyme, the reaction rate is independent of the polymerization degree for DP higher than 6 while with immobilized enzy me a low optimum is found at DP about 8 .

Isolation of Alpha-Amylase Using DEAHP - Starch (II). A. PAŠEK, H. ŠkAchová, Food Research Institute, Prague. 
The work is a continuation of a prec iling study (I). Isolation of amylasa from a pure enzyme (Amylase fungal B grade: Calbiochem, 5000 SKP units/g) or from a cultivation medium (average activity $3 i$ u.B. $/ \mathrm{ml}$ ) was carried out with the use of diethylaminohydroxypropyl starch (DEAI 1" - starch) by a batch method. Samples of DEAHP starch were prepared at the Institute of Chemistry, Slovak Academy of Sciences, Bratislava. The effect of different preparative procedures and forms of the DEAHP starch on enzyme isolation and optimum conditions for a $100 \%$ sorption of enzyme from a solution were studied. The isolation efficiency depends directly on the activity - amount relationship of DEAHP starch; the curve depicting this dependence was determined. The isolation power of DEAHP starch per unit weight and unit activity is about double that found with DEAE starch (cf. I). Elution of amylase from DEAHP sorbate with I $\mathrm{M} \mathrm{NaCl}$ reaches $50 \%$. The above technique can be used for preparing pure alpha-amylase from technical purity preparations.

I, Proceedings of the 11th Congress of the Czechoslovak Microbiological Society, Špindlerův Mlýn-Bedřichov, May 14-16, 1974.

Application of Fungal Biomass in Biosorbent Preparation. R. Jílek, H. Procházka, K. Śtamberg, J. Fuska, Research Institute of Veterinary Medicine, Brno, Slovak Technical College, Bratislava, and Nuclear Fuel Institute, Zbraslav n/Vlt.

Cultivation of fungal isolates from ore mines on specific media containing heavy metals revealed the presence of the heavy metals in the biomass. This ability to take up heavy metals was found to be possessed by all fungi. The rate of heavy metal uptake depended on the kind of mycelium, its age and cultivation conditions. The uptake of heavy metals was also examined in a native mycelium separated after a cultivation on conventional media in contact with heavy metals-containing aqueous phase and in the same mycelium after an irreversible heat denaturation. Undesirable mechanical properties of the mycelium, hich swelling capacity and fuzziness, were improved e.g. by a formaldehyde co-polycondensation with urea. The solidification of mycelial structure yielded a sorbent with sufficient mechanical firmness, preserving the retentive properties of the native mycelium. Its sorption properties were tested not only with heavy metals, but also with other cations, with satisfactory results. Further development of biosorbents should encompass partly the use of all biomass components for the purpose, partly the application of some major components for special purposes. The sorption capacity can be enhanced by activation; in neutral polysaccharides this can be achieved e.g. by phosphorylation, by modification of ion-exchanging and chelating properties, or by binding of some selected cations by co-precipitation. Biosorbents may replace ion-exchanger resins; their principal advantages are high efficiency, especially at low concentrations of metals in solution, and low production costs.

Some Principles of Biological Leaching of Pyrite Minerals. R. Jílek, E. Beranová, Research Institute of Veterinary Medicine, Brno.

The aplication of thione bacteria to biological leaching is a branch of technical microbiology that has been receiving an ever-increasing attention during the last decade. The study of the metabolic functions of thione bactaria was initiated by 
a chance discovery of spontaneous leaching processes in uranium ore in the Elliot Lake region (Ontario, Canada) in the sixties. Since then, fundamental studies, discoveries and technological applications documented the economical advantages of technological procedures utilizing biological leaching. The underlying mechanism of the leaching process is complex; it involves essentially the oxidation of $\mathrm{Fe}^{2+}$ to $\mathrm{Fe}^{3+}$ with a concomitant oxidation of pyrite sulphur to sulphuric acid. Both reactions are catalysed by thione bacteria which utilize the liberated energy in their metabolism. Sulphuric acid, at the same time, disintegrates the structure of the mineral and solubilizes some metals which can then be extracted, e.g. copper, zinc, uranium, gold, ete. Under a favourable qualitative and quantitative composition of the mineral (the presence of the pyrite component) the biological leaching can be used in technological procedure or, if occurring spontaneously, controlled.

Secondary Metabolites of Penicillium stipitatum Thom. II. Substances of Lipid Character. J. Fuska, V. Komax, M. Adamková, Department of Technical Microbiology and Biochemistry, Faculty of Chemical Technology, Slovak Technical University, Bratislava.

On the Czapak-Dox medium, Penicillium stipitatum Thom produced as a major active metabolite the antibiotic PSX-1 together with a considerable amount of lipids. Both antibiotic and lipids were extracted by chloroform and, after solvent renoval, separated by elution from a silica gel column. The resulting lipid fraction was further separated and analyzed by thin-layer and gas chromatography. The composition of lipids extracted from the filtrate was compared with lipids extracted from the filtrate was compared with lipids obtained by extraction of mycelium from the same cultivation. The main components of both lipid fractions were trigylcerides and sterol esters. The increased content of lipids in the filtrate was observed predominantly in connection with a high production of the antibiotic PSX-1; a possible relationship is therefore discussed of the production of the latt $\curvearrowright \mathrm{r}$ substance with the accumulation of lipids in the filtrate.

Effect of Oligomycin and Antimycin $A$ on Submerged Culture of Clavine-Producing Claviceps purpurea $(F r$.$) Tul. S. Mátlová, Z. Ř̈háček, Institute of Microbiology,$ Czechoslovak Academy of Sciences, Prague.

The inhibitor of oxidative phosphorylation, oligomycin $\left(4.88: 10^{-5}\right.$ and $\left.3.6 .10^{-6} \mathrm{M}\right)$ suppressed the growth of the culture and the synthesis of clavine alkaloids irrespective of the culture growth phase. In contrast, antimycin A (1.82.10 and 1.82.1 $\left.10^{-5} \mathrm{M}\right)$, an agent blocking the transfer of electrons from cytochrome $b$ to cytochrome $c_{1}$, evoked antagonistic oscillatory changes in the intensity of culture growth and intensity of clavine production. The results document the significance of unbalanced culture grow th and the respiratory chain, as well as the presence of oxygen, in the synthesis of clavines. They a!so signify the competition of the processes of alkaloid formation with the tricarboxylic acid cycle (Reháček et al., 1971) and support the theory of the positive role of tha clavine cycle in the energetical metabolism of the producing cells (Reháček et al., 1973).

Reháček Z., P. Sajdl, J. Kozová, K. A. Malik, A Ričicová (1971) Appl. Microbiol. $22: 949$.

Řeháček Z., P. Sajdl, A. Křemen (1973) Biotechnol. Bioenerg. 15, 207. 
Protection of Bitumen Insulating Coatings against Biodeterioration. D. HALAMA, Z. Uuı́̌ná, Faculty of Chemical Technology, Slovak Technical University, and Research Institute of Oil and Hydrocarbon Gases, Bratislava.

The biodeterioration of bitumens is caused mainly by various bacterial species. The deterioration rate depends, apart from the bacterial strain, strongly on cultivation conditions (humidity, temperature, $\mathrm{pH}$, organic and mineral nutrients); to a lesser extent it depends also on bitumen origin and composition. In bitumens produced from the same raw material (in Slovnaft, Natl. Enterprise) the rate of decomposition depends further on technology (type of product). The rate can be considerable: under optimum conditions $20-40 \%$ material is decomposed within $3-4$ weeks, the residue losing its chemical and physical properties. The decomposition proceeds solely when the material is in contact with a growing culture, not with resting cells or a filtrate. The material can be protected against the biodeterioration by biocide additives. Unfortunately, the biocides cannot be chosen according to their protective effect on other materials; most conventional biocides either affect negatively the physical properties of bitumen (pentachlorophenolate, Lastanox), or lose their effect when dissolved or suspended in it ( $\mathrm{Hg}$ and $\mathrm{Cu}$ oxides). Satisfactory results under laboratory conditions were obtained with some aliphatic amines and imidazol; the latter compound has also an anticcrrosive effect and increases the adhesivity of the bitumen to a wet surface. Data obtained by different testing methods differ somewhat and the problem is discussed from the methodological viewpoint.

Occurrence of Fungi on Book Leather Bindings from the Baroque Period. A. ORLITA Leather Research Institute, Gottwaldov-Otrokovice.

Examination of books from the 17 th and 18 th centuries kept in library depositories showed that up to $70 \%$ of the leather book binding are degraded to a varying extent. The bindings are made mostly of vegetable tanned leather, parchment leather and white pigskin leather. The degrading factors include both abiogenic (natural ageing, unfavourable climatic conditions) and biological effects (insects, microorganisms). Fungi are responsible for $20 \%$ of the identified damage to the bindings. This study aimed at determining the fungal species active in this specific ecological environment. In two depositories (Postoloprty Castle; Klementinum, Prague) in which leather book bindings were found to suffer from a "mould" growth samples were taken from 16 bindings using the pad smear method. Cultivation on the Czapek-Dox agar and Sabouraud agar at 22 and $28^{\circ} \mathrm{C}$ for $7-28$ days and subsequent isolation yielded 47 strains. The microflora of old binding leather consists mainly of micromycetes of the following genera: Penicillium, Aspergillus, Scopulariopsis, Cladosporium, Paecilomyces, Humicola, Fusarium, mycelia sterilia. Two samples provided also Actinomycetes and six samples contained yeast organisms mainly of the Rhodotorula genus. Representatives of Penicillium and Aspergillus genera formed $60 \%$ of total micromycetes. The most common biodeteriogenes were Penicillium nigricans, Aspergillus versicolor and Scopulariopsis sp. 


\section{ENVIRONMENTAL MICROBIOLOGY}

Effect of Agrobacterium rhizogenes on the Growth and Health Condition of Sprouting Cucumber and Sugar Beet Plants. M. STANĚK, Institute of Microbiology, Czechoslovak Academy of Sciences, Prague.

Bacterial strain Agrobacterium rhizogenes isolated from the surface of the hyphae of the fungus Pythium debaryanum, known as the cause of disease of young cucumber, sugar beet and other plants, stimulated the sprouting of cucumber and sugar beet plants following the spreading of cell suspension on the surface of the seeds. In the presence of Pythium debaryanum whole hyphosphere yielded the bacteria the bacteria-treated plants developed the disease faster than control untreated plants. The effect of the bacterium was lower in the presence of another strain of Pythium debaryanum. Following an artificial contamination of sugar beet seeds with the fungus Phoma betae, $90 \%$ of young plants suffered from the black root disease damping off within 40 days after sowing. A simultaneous treatment of the seed surface with the suspension of Agrobacterium rhizogenes cells prevented the disease. The results showed the specific character of the mutual relationships between microorganisms in the rhizosphere.

Synergistic Relationships of Pseudomonas putida and Some Phytopathogenic Fungi in Plant Rhizosphere. V. Vančura, M. StaněK, Institute of Microbiology, Czechoslovak Academy of Sciences, Prague.

Different strains of Pseudomonas putida were isolated from the rhizosphere of wheat, bean and cucumber plants. Some of them displayed synergistic relationships to phytopathogenic fungi causing root diseases. One strain (K2) stimulated the root disease in bean plants brought about by the fungus Fusarium oxysporum, another (K 11) exerted an adverse effect on the health condition of germinating cucumber and sugar beet plants. Application of cell suspension to the seed surface caused a stimulation or inhibition of seed germination and plant growth depending on the strain used. The experimental strains of Pseudomonas putida were found to produce different types of auxins, gibberellins and kinetines in varying amounts. The relationship of the production of these substances or vitamins to the above phenomena will be the subject of fortheoming studies.

Microorganisms Colonizing the Seeds and Rhizosphere of Sprouting Sugar Beet Plants and their Relationship to Sugar Beet Black Root Disease. D. VeSelÝ, Sugar Beet Research Institute, Semčice.

The study of aetiological agents in the sugar beet black root revealed microorganisms colonizing the seeds, the rhizoplane and the rhizophere of germinating sugar beet plants. The genera of these microorganisms were determined and their relationship to the disease established. The sugar beet plant rhizoplane was found to contain the fungus Pythium oligandrum Drechsler; pathogenic properties of 5 specific of the Alternaria genus and 12 species belonging to Fusarium genus were determined. 
Microbiological analysis served to examine the changes in the colonization of the rhizosphere of sprouting sugar beet plants at various soil moisture levels. The representatives of bacterial and fungal populations were isolated and determined and their possible use was tested in biological protection of sugar beet against the disease.

Gaseous Metabolites of Germinating Seeds of Some Plant Cultivars Resistant and Susceptible to Phytopathogenic Fungi. V. C̆ATská, V. Vančcra, Institute of Microbiology, Czechoslovak Academy of Sciences, Prague.

Volatile and gaseous metabolites released from geminating seeds of fusariousisresistant lentil plants inhibited the germination of macroconidia of Fusarium oxysporum var. orthoceras (App. et Wr.). In a similar manner, the metabolites of a resistant maize cultivar inhibited the germination of Ustilago zeae (Beckm) Unger. chlamydospores. Metabolites from susceptible cultivars of the two plants, on the other hand, stimulated the growth of spores of the respective pathogens. This dissimilar effect of gaseous metabolites of plant seeds of resistant and susceptible cultivars is connected with qualitative and especially quantitative differences in the composition of the liberated gaseous metabolites.

Effect of Polysaccharides of the Bacterium Xanthomonas fuscans and Their Complexes with Heavy Metals on Plant Growth. J. Lasík, Institute of Microbiology, Czechoslovak Academy of Sciences, Prague.

Phytopathogenic bacterium Xanthomonas fuscans Burk, the etiological agent causing bean's fuscous blight, colonizes the rhizosphere of germinating plants and produces polysaccharides which in higher concentrations inhibit the growth of bean and other varieties of plants. The polysaccharides form easily bio-complexes in the presence of heavy metals; the metal ions bound in the complexes suppress the rate of decomposition of the complexes. This phenomenon can be used for evaluating the activity of polysaccharides produced in the rhizosphere and their effect on plant growth. In this paper the effect of the polysaccharides and their bio-complexes in a liquid nutrient medium on plant growth was studied.

Specific and Nonspecific Resistance of Lucerne to Vascular Wilt Pathogens. V. KüDELA, Research Institute of Plant Production, Prague-Ruzyně.

The most common pathogens of vascular wilt of lucerne (Medicago sativa L.) in Czechoslovakia are the bacterium Corynebacterium insidiosum (McCulloch) Jensen and the fungus Verticillium albo-atrum Reinke et Berthold. A set of 148 clones was tested as to resistance and susceptibility to the two pathogens. All four possible combinations of resistance and susceptibility were found indicating a different genetical basis of the Iucerne resistance to either pathogen. Plants with phenotypically identical resistance degree exhibited a different ability to transmit the resistance into the progeny. High resistance to Corynebacterium insidiosum was found in the progeny of bacterial wilt-resistant plants irrespective of the extent of Verticillium resistance of the parent plants. The highest resistance to Verticillium albo-atrum was 
displayed in progeny of parent plants possessing high resistance to both pathogens. The resistance of lucerne to the two pathogens appears thus to be both specific and nonspecific; the resistance to Corynebacterium insidiosum is predominantly of the former, that to Verticillium albo-atrum mostly of the latter type.

Effect of Extra-Root Application of Nutrient-Protective Agent Combinations on Saprophytic and Phytopathogenic Root Microfora - A Biological Protection against Plant Root Diseases. J. Vraxí, Institute of Microbiology, Czechoslovak Academy of Sciences, Prague.

The colonization of the rhizcsphere and the attack of roots by phytopathogens depends, among other factors, on the properties of rhizosphere microflora, e.g. on the occurrence of antagonistic microorganisms. Though of obscure mechanism, an efficient way to modify or regulate the colonization of plant roots by microorganisms is the foliar application of nutrients, antibiotics and herbicides. Papper plants grown on a so-called exhausted soil (after repeated cultivation of a single species in one place) respond to foliar application of urea by a lowered sensitivity to deleterious microorganisms and increased production. The roots of treated plants were colonized to a greater extent by antagonistic bacteria. The possibility is discussed to use the foliar application of nutrient in combination with protective agents as a new approach to the protection of plants against root diseases.

Microorganisms of the Rhizospere of Decorative Plants Grown on Standard and Clay-Peat Substrates and Their Effect on the Health Condition of Plants. E. STAŇroviOpočenská, Decorative Gardening Research Institute, Průhonice.

Clay-peat substrates are usually colonized by lower counts of bacteria and higher counts of fungi than traditional garden soil. The root surface and the rhizosphere of Primula obconica were colonized by approximately constant amount of bacteria but a varying amount of fungi when the substrates were used instead of soil. The root surface of 6 coniferous species (Picea excelca, Abies grandis, etc.) grown on Claypeat substrates exhibited lower counts of bacteria and a higher count of fungi without phytopathogenic fungi of the genera Pythium and Fusarium. This is the reason why plants grown on conventional garden soil suffer from roct diseases more than plants grown on clay-peat substrates.

Effect of Soil Disinfection with Allylisothiocyanaie on Plant Rhizosphere Mivroorganisms. D. Jưzlová, M. Dobrá, M. StTaněk, Mycological Station, Institute of Microbiology, Czechoslovak Academy of Sciences, Prague.

As a continuation of the work by Drobníková and Přikryl (1974), our study showed that the amount of bacteria in the rhizosphere of cucumber plants grown in garden soil and sugar beet grown in the field after a previous soil disinfection by allylisothiocyanate varied depending on the changes due to the disinfection. The changes in the rhizosphere displayed a certain lag behind the treatment. The number of bacteria in cucumber plant rhizosphere changed upon an artificial contamination 
of the seeds with the mycelium of the fungus Pythium debaryanum or with various bacteria. With optimum sowing terms, the growth of plants in disinfected soil was more satisfactory than in control soil. A subsequent contamination of the disinfected soil or seeds with phytopathogenic fungi caused a very rapid spread and development of the infection.

Study of the Microflora of Afflicted Bean Roots (Vicia faba L.). E. Kováčrkoví, Research Institutes for Crop Production, Prague-Ruzyně.

Description is given of fungi isolated from diseased roots of young bean plants from five regions in the Czech Socialist Republic within the last two years. The major representatives of pathogenic fungi colonizing the diseased roots are sections Martielly and Elegans of the genus Fusarium. An isolated occurrence was recorded of Rhizoctonia solani Kühn, Phoma sp. and other saprophytic fungi. Some of the combinations of pathogenic fungi studied displayed synergistic effects.

Microbiological Characteristic of Selected Representatives of Deficient Heavy Soils. I. Rosamová, Melioration Research Institute, Prague-Zbraslav n/Vlt.

Microbiological analyses constitute a complex criterion of the melioration measures in heavy soils. We examined 6 main representatives of extremely heavy soils in various Czechoslovak regions in order to facilitate their classification for melioration purposes. Under otherwise constant composition of the clay fraction (montmorillonite) the biologically most active soils are the chernozem on marl and dark rendzina on marl. This can be ascribed to their higher humus content and relatively favourable physical properties, higher $\mathrm{CaCO}_{3}$ content and more suitable crop rotation. The second group comprises chernozem on tertiary clay and typical rendzina on marl; the biological activity of the latter is low because of the low content of energy sources in organic bonds. The lowest biological activity is found with gleyed brown soil and gleyed meadow soil with extreme conditions (unfavourable physical properties and acidity); the biological properties may be improved by the addition of carbon (organic matter). Effective melioration measures include thus organic fertilizing and liming. The dominant factors limiting the biological activity of heavy soils are thus the air access, soil reaction, and the content of organic matter. Complex melioration should aim at improving these parameters by lightening the texture, adjustment of structure, organic fertilizing and other forms of enhancing the organic matter content, with liming in acid or degraded soils. A high deficiency and consequently a demand for thorough melioration are especially prominent with meadow and alluvial gleyed soils, gley soils, and less pressing in chernozems on carbonate substrates and in rendzinas.

Biomass and Activity of Bacterioplankton in Reservoirs. V. STraškrabová, Institute of Botany, Hydrobiological Laboratory, Czechoslovak Academy of Sciences, Prague.

Reservoirs of depths exceeding $10 \mathrm{~m}$ are characterized by a relatively poor contact of water with sediments and the processes in free water are of decisive importance. 
Yearly average concentrations of bacterioplankton biomass $(b)$ in the Slapy and Klíčava reservoirs in $1964-1970$ were in the range of $0.02-0.57 \mathrm{mg} /$ litre fresh weight. Levels of $(b)$ in excess of $1 \mathrm{mg} /$ litre were only found in the period of allochthonous input (from tributaries or sediment), i.e. during the spring circulation or the first years after the filling of the upper reservoir in the cascade (Orlik above Slapy 1962). The mean algal biomass $(B)$ usually exceeds $(b)$ about tenfold. During the spring and autumn circulation only, the levels of $(b)$ are higher than those of $(B)$. In individual years, the oxygen consumed by bacterial biomass in algae-free water $(a)$, is in the range of $0.2-12 \mathrm{mg} /$ litre $\mathrm{O}_{2}$ per $24 \mathrm{~h}$. In the Slapy Reservoir, $(a)$ is indirectly proportional to the activity of algae (algal production related to their biomass). It increases in the years when the share of algal production in the total input of organic substances drops as compared to the dissolved organics in the inflow. In the Klíčava Reservoir with rather long detention time, $(a)$ is indirectly correlated with algal production irrespective of algal biomass. Algae represent the main source of organic substances for the bactericp'ankton. Their proportion available to the bacteria varies in individual years depending on the activity of algae and their consumption by the zooplankton.

Changes in Bacterial Population during the Decomposition of Fulvic Acid and Lignin in Soil. F. Kunc, J. Rybáǩová, Institute of Microbiology, Czechoslovak Academy of Sciences, Prague.

Samples of structural chernozem soil were enriched by a preparation of AS-lignin and fulvic acid. During a 4-week incubation the following parameters were measured: $\mathrm{CO}_{2}$ production, amount of bacteria growing on Taylor's medium with yeast and soil extract and peptone, relative proportion of bacteria capable of utilizing vanillin, syringic acid, and protocatechuic acid as the sole carbon source, and the ability of soil microflora to oxidize vanillic acid, syringic acid and coumarin. During the incubation $20.4 \%$ carbon from the fulvic acid added and $36.2 \%$ carbon from the lignin was mineralized to carbon dioxide. Comparison of the time course of $\mathrm{CO}_{2}$ formation from the substrates with the bacterial counts during the incubation hinted at the participation of the bacteria in the digradation process. A relationship was also proved to exist between the degradation of the complex polyaromatic compounds used and the metabolism of simpler aromatic substances in the soil. The enriched samples exhibited a marked increase in the percentage of bacteria capable of utilizing vanillin, syringic and protocatechuic acids. Soil suspension prepared from the enriched samples showed also an increased ability of soil microflora to oxidize vanillic acid, syringic acid and, to a lesser extent, coumarin.

Study of Soil Respiration under Natural Conditions. M. Tesaňová, J. GLoser, Institute of Botany, Czechoslovak Academy of Sciences, Brno.

Field measurements of $\mathrm{CO}_{2}$ production from the soils of two vegetatively different meadow coenoses formed the basis of the study of the total carbon balance of the soils of these habitats. The measuring method (absorption technique, Montheith et al., 1964) provided information on both the total $\mathrm{CO}_{2}$ expenditure from the top humus-soil-roots system and the $\mathrm{CO}_{2}$ production by the top humus alone. Root respiration was estimated from laboratory experiments. When the total $\mathrm{CO}_{2}$ expen- 
diture by the top humus-soil-roots system is taken as $100 \%$ then the top humus respiration attains $10 \%$, root respiration (soil profile $0-10 \mathrm{~cm}$ ) $46 \%$, and $44 \%$ is due to the actual soil respiration. The last value is used for determining the amount of decomposed organic matter in soil in a given time interval.

Metabolic Activity of Heterotrophic Bacteria in Surface Water. B. Tržılová, L. MrKLošovičová, Institute of Experimental Biology and Ecology, Slovak Academy of Sciences, Bratislava.

The metabolic activity of vegetative and sporulating bacteria isolated from the Danube water was investigated using the following substrates: arabinose, xylose, glucose, sucrose, cellobiose, serine, aspartic acid, lysine, pyruvic acid and succinic acid. The highest oxygen consumption in vegetative forms cultivated at $22^{\circ} \mathrm{C} / 72 \mathrm{~b}$ and $37^{\circ} \mathrm{C} / 48 \mathrm{~h}$ was found with serine (108 and $140 \mu l \mathrm{O}_{2} / \mathrm{mg} \mathrm{N}$, resp.), aspartic acid (115 and $80 \mu \mathrm{l} \mathrm{O}_{2} / \mathrm{mg} \mathrm{N}$ ) and glucose (68 and $106 \mu \mathrm{l} \mathrm{O}_{2} / \mathrm{mg} \mathrm{N}$ ). Substantially lower was the metabolic activity in sporulating bacteria $\left(22^{\circ} \mathrm{C} / 72 \mathrm{~h}\right.$ and $\left.37^{\circ} \mathrm{C} / 48 \mathrm{~h}\right)$; the relatively highest utilization was recorded with glucose $\left(48\right.$ and $\left.66 \mu \mathrm{l} \mathrm{O}_{2} / \mathrm{mg} \mathrm{N}\right)$ and serine $\left(36\right.$ and $40 \mu \mathrm{l} \mathrm{O}_{2} / \mathrm{mg} \mathrm{N}$ ) and at $22^{\circ} \mathrm{C}$ also with aspartic acid $\left(49 \mu \mathrm{l} \mathrm{O}_{2} / \mathrm{mg} \mathrm{N}\right)$. All bacteria under study utilized lysine and arabinose at $22^{\circ} \mathrm{C}$ only. On the other hand, sporulating forms were unable to utilize arabinose, sucrose, xylose and succinic acid.

Properties and Production of an Exocellular Polysaccharide Formed by Some Strains of the Bacterium Xanthomonas fuscans Isolated from the Rhizosphere. J. LAsík, J. KoNíč́k, Institute of Microbiology, Czechoslovak Ačademy of Sciences, Prague.

The composition and propertics of a polysaccharide produced by bacterial strains of the genus Xanthomonas were studied in view of its possible role on the roots and in the rhizosphere and its toxic properties causing fuscous blight of the host plant. A bacterium producing into a mineral medium an exocellular polymer of the glucomannan type utilized glucose, sucrose, starch, and to a lesser degree also arabinose and $\mathrm{D}$-xylose and did not utilize lactose. It utilized preferentially rich organic media, liquified gelatine and did not form indole. The exocellular polysaccharide consisted of $\alpha$-D-glucose, $\beta$-D-glucose, mannuronic acid and $\mathrm{D}$-glucuronic acid. The polysaccharide production was of about $30 \%$ per sucrose added (dry weight of $2 \% \mathrm{w} / \mathrm{w}$ ). To increase the efficiency of the industrial fermentation of the polysaccharide, an attempt was made to obtain mutants by means of $N$-methyl- $\bar{N}$-nitroso- $N^{\prime}$-nitroguanidine in a concentration of $1 \mathrm{mg} / \mathrm{ml}$. The procedure yielded a number of mutants which were then studied with respect to the production and quality of the exocellular polysaccharide. Mutant strains with white pigmentation reverted extensively to the parent forms.

Biocomplexes of Soil and Rhizosphere Bacteria and Their Decomposition. J. Lasík, S. Gordien ko, Institute of Microbiology, Czechoslovak Academy of Sciences, Prague and Institute of Microbiology and Virology, UAN, Kiev.

The ability of polysaccharides to bind the metal ions affects the activity of soil microorganisms. The study of the ecological function of polysaccharides in the soil 
requires to know the reasons for their high resistance to bacterial decomposition. We tested the exocellular polysaccharides isolated from soil bacteria of the genera Xanthomonas, Achromobacter and Pseudomonas. Initial $\mathrm{pH}$ of the polysaccharides was between 6.7-7.2. The potenciometric titration curves of individual polysaccharides differred in their position. The peaks on differential potenciometric titration curves of some bacterial types were in the acid region, that found with Xanthomonas was in the alkaline region, signifying the presence of a strongly acid group in the polysaccharide of this bacterium. Higher concentration of metal ions caused an increase in this " $\mathrm{pH}$-effect" and in the complexing power. Together with the formation of metal hydroxides biocomplexes were formed. The ability of metal ions to entrap adsorption polysaccharide particles corresponded to the intracomplex stability of these compounds. In Xanthomonas-polysaccharide the affinity followed the sequence: $\mathrm{Fe}^{3+}>\mathrm{Cu}^{2+}>\mathrm{Zn}^{2+}>\mathrm{Mn}^{2+}$. The cations bound in the complex reduced the degradation rate and its utilization by bacterial culture in vitro.

Effect of Foliar and Soil Application of Urea on Wheat Rhizosphere Microflora. J. VRANŕ, Institute of Microbiology, Czechoslovak Academy of Sciences, Prague.

Wheat grown in vegetation pots was treated as follows: (1) Control without treatment; (2) Above-ground organs were treated with 0.2 g urea (4 sprayings at 2-day intervals); (3) Application of $0.1 \mathrm{~g}$ urea on the leaves and $0.1 \mathrm{~g}$ per $1.5 \mathrm{~kg}$ soil at the time of the 3 rd spraying; (4) $0.2 \mathrm{~g}$ urea was added to $1.5 \mathrm{~kg}$ soil. $1-5$ Weeks after the last application the counts of fungi and bacteria in rhizosphere soil and oxygen consumption were determined. The bacterial counts after the foliar application increased by $21 \%$, after combined treatment by $8 \%$ and after soil treatment by $4 \%$. The numbers of fungi, on the other hand, dropped by $16 \%$ following the foliar spray and increased by $13 \%$ and $25 \%$ after combined and soil treatment, respectively. The mycoflora consisted mainly of the genera Penicillium and Fusarium; the occurrence of the latter genus was lower in all variants, the difference being $26 \%$, $21 \%$, and $18 \%$ after the individual treatments as list $\in d$. The relative occurrence of Fusarium was increased following all three types of treatment: foliar spray $(21 \%)$, combined treatment $(13 \%)$, soil treatment $(3 \%)$. Other fungal genera, including Aspergillus, Cladosporium, Trichoderma, and others were found only sporadically and irregularly, the type of treatment having nevertheless a marked effect. Oxygen consumption by rhizosphere soil of plants whose above-ground organs were treated with urea was higher than control, the combined or soil application causing only a small increase. Thus the foliar application of urea represents a qualitatively different modification of the plant life as compared to direct administration to soil affecting consequently in a different manner the biological relationships and microflora of the rhizosphere.

Effect of Structural Elements on Microbial Conversions in Soil. M. Ambrožová, Basic Agrotechnical Research Institute, Hrušovany near Brno.

Microbial conversions were studied of organic substances added to soils fractionated into aggregates of different size by means of sieves. The results point to a strong influence of the spaces between individual structural elements. These spaces form 
an environment in which the microbial processes are affected predominantly by physical factors. Maximum development of protein-degrading bacteria and the intensity of proteolytic activity as well as maximum phosphatase activity were observed in soils enriched in proteins and consisting of aggregates $3.5-5 \mathrm{~mm}$ in size. Soils mixed with ground straw displayed the most intensive development of aerobic microflora at aggregats size of $5-7 \mathrm{~mm}$. On urea addition the maximum rates of microbial development and biological nitrogen conversions were attained in soils consisting of $3.5-7 \mathrm{~mm}$ aggregates. The liberation of nutrients from organic substances and their conversion into nutritive compounds accessible to consumption by plants are different when the original substances are embodied in aggregates or when they are freshly added in the form of fertilizers.

Cellulose Decomposition by Myxobacteria at Different Temperatures. J. PoKoRNá, S. Bönischová-Franklová, Research Institutes for Crop Production, Prague-Ruzyně.

The course of decomposition of cellulose at different temperatures $(8,28,35,42$ and $55^{\circ} \mathrm{C}$ ) was studied in model experiments using soil enriched by inorganic nitrogen. In the first phase of incubation (after two weeks) the cellulose decomposition by myxobacteria was fastest at $35^{\circ} \mathrm{C}$ and satisfactory at $28^{\circ} \mathrm{C}$. In the second phase (after four weeks) the decomposition at $28^{\circ} \mathrm{C}$ exceeded that at $35^{\circ} \mathrm{C}$. The extreme temperature of $55^{\circ} \mathrm{C}$ was unsuitable for decomposition of cellulose by micobacteria. At $8^{\circ} \mathrm{C}$ the rate of decomposition is not significantly lower than at higher temperatures; an intensive cellulose decomposition takes place in a broad temperature range of $8-25^{\circ} \mathrm{C}$.

Effect of Different Temperatures on Mineralization of Organic Substances in Soil. B. Novák, J. Kubát, Research Institutes for Crop Production, Prague-Ruzyně.

The influence of temperature on the process was studied in the range of $20-30^{\circ} \mathrm{C}$ using respirometric methods. In short experiments (up to $16 \mathrm{~h}$ incubation) a temperature rise of $10^{\circ} \mathrm{C}$ caused a doubling in the mineralization of the substrate. Mineralization of soil organic matter and glucose added to the soil was affected to the same extent by increased temperatures. A simultaneous addition of glucose and ammonium sulphate potentiated the effect of temperature probably due to an acceleration of the synthesis of enzymes catalyzing glucose decomposition at elevated temperatures. On prolonged incubation (up to 4 days) the extent of mineralization is strongly affected by the stabilization of the non-mineralized portion of the substrate. The effect of the stabilization may exceed that of the temperature.

Effect of Some Biocides on Cell Metabolism (Escherichia coli) in Aqueous Medium. I. Daubner, E. Ježová, D. Tóth, Institute of Experimental Biology and Ecology, Slovak Academy of Sciences, Bratislava.

Escherichia coli cells were grown in meat-peptone broth, centrifuged and washed and then transferred to Danube or distilled water previously sterilized in an auto- 
clave (1.2 atm $/ 20 \mathrm{~min})$. They were then incubated for 2 weeks at $20^{\circ} \mathrm{C}$ under aeration (magnetic stirrer) in the presence of herbicides (lindane) and fungicides (dithane, orthophaltane, topsin and benlate) and the effect of the agents on cell respiration activity and transhydrogenation capacity of the cells was studied. Determination of reproduction-capable cells on meat-peptone agar served to characterize the rate of cell death. Of the agents under study lindane stimulated slightly both respiration and transhydrogenation activities, benlate, orthophaltane and topsin were inactive (no difference from control), dithan had an inhibitory effect. Its inhibitory effect on the respiration and transhydrogenation capacity of cells incubated in both media increased in a linear manner in concentration range of $0.05-50 \mu \mathrm{g} / \mathrm{ml}$. Under identical experimental conditions the count of reproduction-capable cells declined more slowly than the above mentioned metabolic parameters.

Microbiological Aspects of Surface and Underground Water Contaminated by Agricultural Wastes. L. Lecianová, Water Research Institute, Ostrava.

Intensification of agricultural production brings about an increased eutrophication of our surface waters and contamination of underground waters. Hydromicrobiological research deals with agricultural wastes and wastewaters which have not yet been evaluated according to water-sanitary criteria as well as to their effects on water quality. During the last three years all potential sources of feed-lot wastes effecting the bacterial contamination of surface and underground water were under study. These sources included feed-lot wastes, pig liquid-manure, liquid-manure from breeding cattle (milk-cows, heifers, calves) and horses, wastewaters from poultry-farms, silage seepage, drainage and soil runs-off, washing wastewaters from tractor stations. General microbiological method for waste-, surface and underground water analysis was supplemented with the determination of a broad spectrum of present physiological strains of microorganisms participating in the conversion cycle of carbon, nitrogen, sulphur and phosphorus with the aim to find a bacterial indicator for waters contaminated by agricultural activities. The toxic effects of agricultural wastes on water organisms were also studied. Measures were devised to eliminate or restrict the agricultural contamination; the measures have helped considerably in improving the quality of water in our waterways.

Effect of Mycelial Wastes from Antibiotics Production on the Course of Compost Ripening and Some Microbiological Processes in Soil. A. Śtroová, A. Seduáčková, V. Wagnerová, M. Štifter, Research Institutes for Crop Production, Prague-Ruzyně.

Utilization of mycelial wastes from antibiotics production in composts appears promising since direct application of the wastes to soil entails a negative influence of residual substances on soil microbial populations. The mycelial wastes from erythromycin, oxytetracycline and penicillin production used in our experiments contained $1100-8000$ biologically active residues per $1 \mathrm{~g}$. An addition of $20 \% \mathrm{my}$ celial wastes affected compost temperature; especially in the first 14 days of ripening; the effect of erythromycin was more powerful than that of oxytetracycline and penicillin. In this period an inhibitory effect is observed on both meat-peptone 
agar and starch agar, partially also on Thornton's agar. A marked increase in the number of micromycetes is simultaneously observed on Jensen's agar, particularly during the first week of ripening. From the third week on the number of microorganisms in the compost increases and a maturation of the compost proceeds accompanied by increased $\mathrm{CO}_{2}$ production; carbon mineralization, on the other hand, is lower than in check. The study showed that the mycelial wastes themselves exert a negative effect on microbiological and biochemical processes in soil while compost alone have a favourable influence. The wastes suppressed the proportion of cultivated groups under study as well as both basal and potential soil respiration. A positive relationship was found between the addition of mycelial wastes to composts on the one hand and biochemical and microbiological processes in soil and maize yields on the other.

Drying During Compost Ripening as a Means of Higher Utilization of Various Sludges. F. Löbl, J. Váx̌a, A. Štiková, J. Košatková, Research Institutes for Crop Production, Prague-Ruzyně.

Agricultural utilization of liquid sludges (sewage sludges, liquid manure) is limited by the vegetation period. Compost production, on the other hand, makes possible an every-day processing of both solid and liquid fertilizing wastes. Addition of a drying step into compost maturation permitted an increase of the utilization of sludges from $16 \%$ to $100 \%$ or more (referred to raw material proportion). Technological tests with the $\mathrm{BS}-6$ drier at $\mathrm{G}_{1}=11.2 \mathrm{t} . \mathrm{h}^{-1}, \mathrm{G}_{2}=7.87 \mathrm{t} \cdot \mathrm{h}^{-1}$, i.e. evaporation rats of $3.4 \mathrm{t} \cdot \mathrm{h}^{-1}$, and at input temperature of $240^{\circ} \mathrm{C}$ and output temperature $42{ }^{\circ} \mathrm{C}$ yielded an increase in dry weight from $53.9 \%$ to $75.9 \%$. Repeated dosage of sludges served to adjust the water content the compost was left to ripen for a short interval, and the drying procedure was repeated. The amount of bacteria growing on MPA, starch and Thornton's agar remained constant throughout the drying run; as an exception, the number of bacteria on Thornotn's agar during the second drying cycle decreased slightly. The increased utilization of sludges led to an increased $\mathrm{CO}_{2}$ production and a decreased stability of organic substances which indicates a gradual accumulation of organic compounds apt to be microbially decomposed. The addition of sludges thus has a positive effect on the conversions of organic matter in the compost.

Technological Procedures in Disposal and Utilization of Solid Town Refuse With Respect to its Effect on Soil and the Natural Environment. F. Löbl, J. VÁŇA, A. ŠTrková, Research Institutes for Crop Production, Prague-Ruzyně.

The disposal of solid town refuse is currently done by dumping. Despite the demand for controlled dumping, the dumping grounds are mostly managed in an arbitrary manner. The decomposition of organic substances in these wild dumping ground is thus uncontrolled and is subject to climatic influences. Under favourable conditions the decomposition process is initiated by a considerable proliferation of bacteria growing on MPA, Thornton's agar, micromycetes growing on Jensen's agar, and actinomycetes growing on Thornton's agar. The development of the microflora proceeds according to the ambient physical conditions and depends on the content of decomposed organic substances. The siftings from these dumps contain active 
microflora even after several years. The composting of these wastes causes an immediate improvement in hygienic conditions; the activity and development of the microflora is controlled by technological means (turning, irrigation, addition of liquid sludges and nutrients). Unmanaged dumping grounds represent thus a potential danger to the environment, surface and ground water. The composts containing the refuse have a high level of stable organic substances and autochthonous microflora but lack pathogenic microorganisms. Organic fertilizing by these composts promotes the proliferation of soil microflora and represents thus the most effective way of utilization of the refuse.

Application of Biochemical Tests in Soil Microbiology. B. Novík, Research Institutes for Crop Production, Prague-Ruzyně.

The changes in soil brought about by soil microflora can be appraised by a number of tests. The rate of conversions of organic substances in soil can be evaluated by respirometric methods in various modifications. The stability of organic substanc es can be assessed from the values of respirometric test quotient $G: B$ or $N G: B$. Physiological utilization of soil nitrogen and its changes can be indicated by a respirometric test - $\mathrm{N}: \mathrm{B}$ or $\mathrm{NG}: \mathrm{G}$, cellulolytic test and a combination of ammonification and nitrification tests. No satisfactory method has as yet baen applied to the determination of soil phosphorus availability. The testing of physical soil properties by the respirometric test is still of an empirical character.

\section{MEDICAL AND VETERINARY MICROBIOLOGY}

The Control Role of Immune RNA in the Immune Response. I. The Origin and Transfer of Genetic Information. A. SokoL, School of Microbiology and Zoohygiene, Veterinary Faculty, Košice.

Similarly as in oncornavirus infections, even the antigenic stimulation with Pol flagellin results in formation of so called immune RNA (i-RNA) in activated immunocompetent cells. The i-RNA can be serially transferred and is capable of active replication within the recipient cells. In addition, immune $R N A$ alone, i.e. in the absence of corresponding antigen, is able to induce both the primary immune response and proliferation of a clone of cells possessing an immunological memory. The memory cells carry the information on the i-RNA dependent DNA polymerase (revert transcriptase) which can synthetise even in the cellulai syst $2 m$ one additional DNA from deoxiribonucleotides, provided the corresponding immune RNA is used in vitro as a tomplate. Immune RNA is not identical with the Lawrence's transfer factor. It seems that i-RNA plays a control role in the immune response and, further, that the additional DNA, as a product of memory cells, represents an intermediate stop in the process of antibody formation which is specified by the revert transcriptase which employs the i-RNA information as a primar. 
The Control Role of Immune RNA in the Immune Response. II. Isolation, Fractionation and Purification of Immune RNA. M. Novák, A. SokoL, F. Hrušovsk $\dot{\mathbf{Y}}$, Z. Koppel, M. Fotwa, School of Microbiology and Zoohygiene, Veterinary Faculty, Košice.

The immune response of the lymphoid system to antigen represents a complex phenomenon which is controlled at the genetic level by transfer of informations; in addition, various specific and non-specific factors are involved in this process. Immune RNA belongs to specific components. According to contemporary knowledge, this RNA can induce alone, i.e. without antigen, primary immune response and immunological memory in immunocompetent cells. In addition it is capable to transfer immunological memory within allogeneic models from one individual to the other and, at the genetic level, to determine reversibly the specific immune response. The aim of the present work was to isolate various fractions of RNA from the liver, spleen, lymph nodes and from a purified population of lymphoid cells from the circulating pool of pigs. The samples were obtained at various intervals after immunization of pigs with flagellin or Salmonella tennessee. Isolated RNA was further purified and fractionated by chromatography on the column with methylated albumin and kieselguhr. The purity of 9 fractions of RNA was determined spectrophotometrically by using the purity coefficient and by polyacrylamide gel. Svedberg units of individual RNA fractions were determined by using the Beckman-model $\mathrm{E}$ analytical ultracentrifuge. The contamination of RNA preparations with antigen was excluded spectrophotometrically, by the Lowry's method and by polyacrylamide gel. The antigen-informatory activity of individual fractions of RNA was tested by immunization of pigs.

The Control Role of Immune RN $A$ in the Immune Response. III. Induction of Humoral Immune Response in Pigs by Immune $R N A$. F. Hrušovský, A. Sokol, M. Novák, M. FotTa, School of Microbiology and Zoohygiene, Veterinary Faculty, Košice.

Individual RNA preparations were injected by different routes to young pigs (average weight $40 \mathrm{~kg}$ ), divided into 11 groups. Each group comprised 10 animals. Various RNA preparations were injected according to following scheme: group 1 whole RNA from lymph nodes; group 2 - whole RNA from the spleen; group 3 - whole RNA from the liver; group 4 - fraction I of the lymphocytic RNA fractionated on phosphate-cellulose; group 5- fraction II from lymphocytic RNA fractionated on phosphatecellulose; group 6 -- fraction III of the same RNA preparation; group 7 - whole RNA from the liver; group 8 - whole RNA from the spleen; group 9 - whole RNA from the liver; group 10 - flagellin; group 11 controls: half of control animals received normal, non-immune RNA (subgroup 11a), the second half remained untreated (subgroup 11b). After 3 weeks, groups $1-5$ were injected with flagellin and groups $6-9$ received the secondary dose of i-RNA. Group 10 and control subgroup 11 a were injected with flagellin, subgroup $11 \mathrm{~b}$ was left without treatment. The dynamic of the specific immune response was studied at regular intervals for 2 months. Sera under study were first absorbed with the $O$ antigen of Salmonella cholerae suis and the titre of anti-H antibodies to Salmonella tennessee was determined by using the slow tube agglutination and immunoprecipitation. The positive secondary immune response was found in groups 1, 2, 3, 6 and 10 ; dubious response was in groups 4,5 and 11 , negative response was recorded in groups $7,8,9$ and $11 \mathrm{~b}$. 
Activation of Lymphoid Cells by Mitogens During the Ontogenic Development. J. HoFman, M. Pospíšil, F. Kovář́̃ , V. Ȟ̌íbalová, Department of Immunology, Laboratory of Gnotobiology, Institute of Microbiology, Czechoslovak Academy of Sciences, Prague, and Institute of Hygiene and Epidemiology, Prague.

The $B$ and $T$ lymphocyte system (derived from the bursa Fabricii and from the thymus) was defined in mice and some other animal species. The ability of cells to respond to mitogens by blast transformation in vitro serves as one of a number of criteria determining this system. In our present work, the response of cells to B and $\mathrm{T}$ mitogens was studied during the ontogenic development in pigs: on the 38th, 67th and 112 th day of gestation compared with the activity of cells during the postnatal period. It was found that during intrauterine life, lymphoid cells of the fetal liver and bone marrow responded mostly to B mitogens e.g. bacterial lipopolysaccharide (LPS), lipid A and pokeweed mitogen (PWM), the latter being known to stimulate both $T$ and $B$ cells. The activity of cells of these organs decreased during the postnatal period, mainly in the liver. The spleen cells responded during the whole observation period more intensively to $\mathrm{T}$ mitogens, i.e. to phytohaemagglutinin, Concanavalin A, erythrogenic toxin and PWM; however, even the reaction to LPS and lipid A was comparable to that observed in other animal species. Cells isolated from the thymus were transformed by $\mathrm{T}$ mitogens and PWM only. It therefore follows that during the early stages of development when the liver fulfills mainly the haemopoietic function, the lymphoid cells respond mainly to bacterial LPS and this responsiveness persists up to the end of the gestation period. The reaction of cells of primary and secondary lymphatic organs to $B$ and $T$ mitogens is similar to that found in other animal species including man. The nature of the $\mathrm{B}$ and $\mathrm{T}$ system as demonstrated in our experimental model is discussed in comparison to other models.

Sensitivity of Lymphoid Cells to the $B$ and $T$ Mitogens. Comparison of Several Animal Species and Man. M. Pospíšil, J. Hofmax, F. Kovářủ, M. Campa, Department of Immunology, Laboratory of Gnotobiology, and Institute of Microbiology, Czechoslovak Academy of Sciences, Prague.

Mitogenic substances of the lectine type and various bacterial exo- and endoproducts became during the past decade an important tool for selection of lymphoid cells from different organs. Particular attention is focused on bacterial lipopolysaccharides as B mitogens. In the present work, we compared the effect of lipopolysaccharide (LPS) from Salmonella typhimurium and Escherichia coli including their lipids $\mathrm{A}$ with the effect of pokeweed mitogen and $\mathrm{T}$ stimulators (belonging mostly to substances of plant origin) on human and animal cells. Various LPS preparations and their lipids $A$ possess comparable activity if tested on cells of a sensitive animal species. Detoxified LPS preparations lost their stimulatory activity. Using the spleen cells of mice (strain Balb/c, Black/Sn) a comparable response found, the stimulation index (S.I.) being for $B$ substances $5-10$, for $T$ substances $15-20$. The highest response was recorded in strain $B 10$, the S.I. being up to 30 , i.e. of the same value as for $\mathrm{T}$ mitogens. On the other hand, mice of the strain $\mathrm{C} 3 \mathrm{H} / \mathrm{He} 3$ did not respond selectively to LPS or lipid A even though they responded in vitro to pneumococcus polysaccharide and PPD, i.e. to substances belonging also to thymus-independent antigens. Positive response to LPS could not be obtained even in media enriched with "highly active" fetal calf serum. A complete failure of responsiveness was ob- 
served with blood and spleen cells of rabbits, peripheral and lymphoid cells of monkeys (Maccacus rhesus) and with human cells. Pig cells were found to respond to LPS already during early ontogeny (see Hofman et al., this symposium). Based on these facts, we discuss the problem of the genetic nature of unresponsiveness, the polyclonal type of response induced in vitro to various antigens and finally the possibility of the helper role of the thymus-dependent immunogen in the immune response to thymus-independent antigens.

The Role of Secretory IgA and of Local Resistance to Aujeszky Disease Virus in Pigs. A. Sabó, J. RaJč́ni, Institute of Virology, Slovak Academy of Sciences, Bratislava.

The local resistance of mucous membranes of nasopharynx and tonsils to reinfection porsisted in seronegative six-week-old pigs up to the 80 th-90th day after infection with the Aujeszky disease virus (strain Top, dose $10^{6}$ TCID). The possible role of secretory $\operatorname{IgA}$ ( $\mathrm{IgA}$ ) in this phenomenon was investigated. The antibody response in serum appeared on the 8th day aft infection; however no virus-specific neutralizing antibodies were detactable in nasopharyngeal secretions. Antibodies of the IgA type were present in secretions at all intorvals tested; however, their virus-specific activity (measured by indirect immunofluorescence) was minimal. In addition, no significant increase in numbers of IgA-producing plasma cells was found by immunofluorescence in the mucous membranes of nasopharynx and tonsils. Thus the result of our experiments did not prove a significant role of virus-specific $\operatorname{Ig} A$ antibodies in the local infection of nasopharynx of pigs infectad by the Aujeszky disease virus.

Immunofluorescent Localization of IgA in Mucous Membranes and Lymphatic Tissues of Pigs. J. Rajčáni, J. Matis, B. Styk, A. Sabó, Institute of Virology, Slovak Academy of Sciences, Bratislava.

Secretory $\operatorname{IgA}$ (s IgA) was purified from pig colostrum and intestinal content by tripple gel filtration using Sephadex G 200-DEAE cellulose-Sephadex G 220 . Elimination of cross-reactions of anti- $\mathrm{s} \operatorname{IgA}$ serum with other immunoglobulins and non-specific reactions with other proteins, present in trace amounts in our antigen, was achieved succesfully with an immunosorbent prepared from pig serum. Antisera were employed both for indirect immunofluorescence staining and for preparation of a direct anti-s IgA conjugata. Aftor a single absorption, the reactivity of antis IgA with serum IgA (prepared by a four-fold gel filtration of the immunoglobulin fraction of pig serum) remained unaffectod. Significant IgA fluorescence was observed in cells of serous glands in the mucous membrane of the nose, pharynx and bronchi, further in epithelium of mucous membranes, in crypts epithelium cells of tonsilar and finally in Lieberkühn glands of the small intestine. IgA-producing plasma cells were found under the epithelium of above mentioned mucous membranes. Germinal centres containing IgA-positive lymphoid cells were found in tonsils and regional lymph nodes of the pharynx, bronchi and mesenterium. 
The Development of Enzymatic and Migratory Activity of Macrophages. D. Kotulová, Institute of Medical Microbiology and Immunology, Medical Faculty, Comenius University, Bratislava.

When comparing the enzyme activity of extracts of rabbit macrophages from alveolar washings and from peritoneal exudate obtained by paraffin oil irritation, it turned out that the activity of proteolytic enzymes operating at $\mathrm{pH} 3.5$ and activity of acid phosphatase was lower in peritoneal cells than in alveolar macrophages. This difference is probably given by stimulation of alveolar macrophages with antigens present in the air whereas peritoneal macrophages maturate in sterile environment. Using the capillary technique it was shown that alveolar macrophages possessed even higher migratory activity as compared with peritoneal cells. It was further found that mouse peritoneal macrophages can enhance to a high degree their enzymatic activity after stimulation with certain antigens (e.g. Escherichia coli, sheep erythrocytes, precipitated human serum albumin). The degree of stimulation is dependent on both antigen dose and time interval after administration.

The in Vivo and in Vitro Immunological Properties of Toxoplasma gondii and its Fractions Obtained on DEAE Sephadex A-50. G. CATÁR, L. BERGENDI, Institute of Parasitology, Medical Faculty, Comenius University, Bratislava.

Toxoplasma gondii antigen and its concentrated fractions obtained by fractionation on DEAE Sephadex A-50 were used for complement fixation reaction. Guinea pigs were immunized passively with rabbit anti-toxoplasma serum obtained from naturally infected animals. Most severe systemic anaphylactic shocks were observed in guinea pigs injected with soluble antigen of Toxoplasma gondii, milder reactions were elicited by fractions I and II, whereas fractions III and IV yielded either weak or no shock reactions. As regards passive cutaneous anaphylaxis, most intensive reactions were obtained with soluble antigen of Toxoplasma gondii, less intensive with fractions I, II and III and weakest reactions with fraction IV. Soluble antigen of Toxoplasma gondii produced only minute, almost undetectable anaphylactic contraction of the terminal segment of ileum according to Schultz-Dale. The results point to differences between the in vivo and in vitro reactivity of antigens studied.

Protective Antigens in Supernatants of Leptospira Cultures. I. PLEŠKo, Institute of Epidemiology, Medical Faculty, Comenius University, Bratislava.

Immunization of golden hamsters with $2-3$ doses of concentrated supernatants of cultures of virulent or avirulent strains of leptospira yielded a high degree of protection to a challenge with a high dose $\left(10000-1000000 \mathrm{LD}_{50}\right)$ of homologous virulent strain. After repeated administration of this material, however, the protective effect could not be distinguished from the protzction yielded by a vaccine made of concentrated suspension of leptospira killed by phenol. Administration of a single dose of the preparation revealed that the experimental animals were protected not only against the lethal effect (contrary to the protection yielded by the phenol vaccine) but also against the imparent renal carrier state. The long-term 
repeated administration of concentrated supernatants resulted in some cases in a certain degree of a cross, intertype immunity. The nature and possible practical significance of the protective factor is discussed.

Resistance Induced by Listeria monocytogenes. M. Mára, Z. Miková, E. Menčíková, M. Klečáková, Z. Fralová, Laboratory of Special Medical Microbiology, Faculty of Medicine, Charles University, Prague, Institute of Hygiene and Epidemiology, Prague, Institute of Medical Microbiology and Immunology, Faculty of Medicine, Charles University, Prague.

Listeria monocytogenes strain Welshimer, nonvirulent for mice, induced after a single in dose of $10^{8}$ c.f.u./mg 2 to 14 days before infection significant resistance to listeria infection with the virulent strain Brat 1 by 2 to $3 \log$ LD $_{50}$. The immunizing effect was dependent on the dose. The same effect was attained after application of 2 sublethal doses of virulent strain Brat $1\left(10^{3}\right.$ c.f.u per mouse, $\left.\mathrm{LD}_{50}=2 \times 10^{6}\right)$. One dose had no effect. In agreement with studies on the immunizing effect of cell walls (Klasky and Picket, 1968; Rodriguez et al., 1974) the application of $100 \mu \mathrm{g}$ of listeria surface-bound factor $\mathbf{E}_{\mathrm{i}}$ prepated from strain Brat 1 protected against listeria infection (by $1 \log$ LD 50). A weaker protective effect was produced by the application of BCG (0.5 mg per mouse) 1 to 2 weeks prior to infection. A single dose of a suspension of strain Welshimer $\left(10^{8}\right.$ c.f.u $)$ applied to mice infected i.v. with Mycobacterium kansasii strain $200 / 9(0.1 \mathrm{mg}$ per mouse) prevented significantly a loss of weight in mice usually accompanying mycobacterial infection. Beside this effect, after application of 2 doses of the avirulent listeria suspension a temporary significant decrease of the number of living organisms of Mycobacterium kansasii in the lungs of mice by $2 \log$ was observed.

The Phenomenon of "Plaque Formation Without Lysis of Erythrocytes" in Polymorphonuclear Leucocytes. M. KunaY, M. Novák, A. Sokol, Department of Haematology and Blood Transfusion, Medical Faculty, Košice, School of Microbiology and Zoohygiene, Veterinary Faculty, Košice.

We have already previously reported the phenomenon of formation of empty spaces in the layer of diluted peripheral blood which occurred within $24 \mathrm{~h}$ in a special chamber in vitro. We called this effect "plaque formation without lysis of erythrocytes". This phenomenon was originally described in lymphocytes and the mechanism of plaque formation was explained by "pushing off" erythrocytes by a material produced and released from the central cell. Similar phenomenon was described recently by Shelley (Nature, $247: 5435,1974$ ), who claimed that cells which formed the plaque were primarily polymorphs adhering to the glass surface. However, Shelley admitted that even other white cells of the peripheral blood could be involved in plaque formation. In our present work we confirmed, in agreement with Shelley's experiments, that the formation of plaques without lysis of erythrocytes was preceded by adherence of the central cell to the glass surface. Our present results further extend previous data on the plaque forming capacity in the subpopulation of adherent lymphocytes and demonstrated similar phenomenon in activated polymorphs. Our data further suggest that plaque formation without lysis of erythrocytes requires activation of leucocytes in vivo or in vitro. 
The Systemic and Local Antibody Response in Individuals with Lowered Resistance to Infection. F. Franǩx, V. Kubín, F. Naxera, Institute of Experimental Medicine, Czechoslovak Academy of Sciences, Prague, and Department of Otolaryngology, Medical Faculty Hospital, Charles University, Prague.

The aim of the present study was to evaluate various methodic approaches for antibody determination in individuals with trequent recurrentinfections of the respiratory tract. Detarmination of immunoglobulin levels $(\operatorname{Ig} G, \operatorname{Ig} A, \operatorname{Ig} M)$ in serum and saliva did not reveal any causal relationship to decreased resistance to infection in 132 patients. In 52 patients of the same group, smears were prepared from the sediments of saliva and monospecific fluorescent antibodies to $\operatorname{IgA}$, IgG and $\operatorname{IgM}$ were applied. In $39 \%$ of patients, IgA bound to bacteria in the sediment of saliva could be demonstrated by a ring-fluorescence which is typical for reaction with specific antiserum. In saliva sediments of $61 \%$ of patients no fluorescence was found. Thus the immunofluorescence method appears to be most suitable for demonstration of "specific activity" of secretory antibodies i.e. their ability to bind to bacteria present in the oral cavity.

The Effect of Cations on Bacterial Endotoxin. J. Sourek, M. Tichŕ, Institute of Hygiene and Epidemiology, Prague.

Natural occurrence of cations $\mathrm{Fe}, \mathrm{Zn}, \mathrm{Cu}, \mathrm{Mg}$ and $\mathrm{Ca}$ was studied in lipopolysaccharides (LPS) of S-and R-forms of Shigella dysenteriae 1. LPS were prepared either by phenol-water extraction after Westphal or by extraction of bacterial cells with hypertonic solution $\mathrm{NaCl}-\mathrm{Na}$ citrate after Raynaud followed by purification on Sephadex G 200 and Sepharose 4B. LPS of the Westphal type contained the highest concentration of $\mathrm{Mg}^{2+}$ (up to $30 \mu \mathrm{g} / \mathrm{mg}$ ) and the lowest concentration of Fe and $\mathrm{Cu}$ (approximately $0.10 \mu \mathrm{g} / \mathrm{mg}$ ). LPS of the Reynaud type from both $\mathrm{S}$ - and R-strains, contained the highest concentration of $\mathrm{Ca}(\mathrm{up}$ to $13 \mu \mathrm{g} / \mathrm{mg}$ ) and the lowest amount of $\mathrm{Fe}$ (approximately $0.10 \mu \mathrm{g} / \mathrm{mg}$ ). The present work reports conditions under which it is possible to reach even higher concentrations of cations in LPS preparations. It was also shown that the bond between LPS complex and cations is very labile (with the exception of $\mathrm{Fe}^{3+}$ ) and thus the concentration of cations could be significantly reduced by complex-forming agents, e.g. EDTA. It was further shown that LPS of $\mathrm{R}$-forms were more labile to the effect of cations because they formed with certain cations less soluble complexes than LPS of S-forms. Studies on biological properties of LPS did not reveal any correlation between the toxicity for mice and Limulus test. It seems that increased concentration of $\mathrm{Fe}$ (mainly $\mathrm{Fe}^{3+}$ ) and $\mathrm{Mg}$ can influence negatively the toxicity of LPS. Our results suggest that bacterial endotoxins may participate in the transport of certain cations across the cell membrane.

Studies on Peritoneal Exudate Cells Stimulated by Non-Specific Stimuli in Mice. L. JARošková, Department of Immunology, Institute of Microbiology, Czechoslovak Academy of Sciences, Prague.

Changes in the population of peritoneal exudate (PE) cells were studied after an intraperitoneal injection of various materials possessing adjuvant activity (proteose 
peptone, Bordetella pertussis, lipopolysaccharides of Salmonella typhimurium and Escherichia coli). Optimum doses and time of administration of tested substances were found for significant activation of macrophages: faster and firmer adherence to surfaces, enhanced proportion of cells yielding positive acid phosphatase test, higher level of acid phosphatase in the total population of PE cells. In PE cells of mice stimulated with peptone, a correlation between the quantitative increase of cells of the macrophage type and number of cells giving positive acid phosphatase test, was found; such correlation could not be demonstrated in PE cells of mice stimulated with substances of the endotoxin type. Contrary to peptone, certain amounts of lipopolysaccharides induced higher proportion of lymphocytes and higher level of acid phosphatase in the total population of PE cells. Using the ${ }^{125} \mathrm{I}$ labelled anti-immunoglobulin serum, the number of lymphoid cells, carrying surface immunoglobulin receptors were established by autoradiography. The proportion of Ig-bearing lymphocytes decreased in the population of $\mathrm{PE}$ cells after an in vivo administration of endotoxin. The recent findings together with previous results obtained in studies on ultrastructure of $\mathrm{PE}$ cells demonstrate that the substances studied possess various degree of stimulatory effectiveness on cells of both lymphoid and macrophage series.

Ultrastructural Studies on the Mechanism of Thrombocytolytic Activity of Streptococcal Peptidoglycan. M. R Ýc, J. RotTA, Institute of Hygiene and Epidemiology, Prague.

Peptidoglycan of group A streptococcus possesses significant biological activity: it can lyse thrombocytes of certain animal species. This activity depends on the presence of plasma in the medium; it is generated even in $1: 10$ diluted plasma or even in blood serum. The plasma factor, which is responsible for lysis of rabbit thrombocytes after incubation with peptidoglycan of group A, type 6 streptococcus, has been studied. Peptidoglycan was prepared from cell walls by host formamide treatment. Morphological changes of thrombocytes were studied on ultrathin sections. It was demonstrated that the thrombocytolytic activity of peptidoglycan was blocked by inactivation of complement components by heating of plasma at $56^{\circ} \mathrm{C}$, its incubation with $\mathrm{NH}_{4} \mathrm{OH}$, zymosan or EDTA. Similar blocking effect was obtained by addition of antipeptidoglycan antibodies to reaction mixture. These results showed that the lysis of thrombocytes by streptococcal peptidoglycan involves immunological mechanisms.

Lipopolysaccharides in Rickettsia. Š. SchrameK, R. Brezina, Institute of Virology, Slovak Academy of Sciences, Bratislava.

Rickettsia possess a similar structure of cell wall as gramnegative bacteria. Using the phenol extraction procedure according to Westphal, we extracted serologically active components from rickettsia of the genus Coxiella (Coxiella burnetii, phase I) and of the genus Rickettsia, belonging to the typhus (Rickettsia prowazekii, Rickettsia typhi, Rickettsia canada) spoted fever (Rickettsia conorii, Rickettsia sibirica) group. The active components were released from Coxiella burnetii into the water phase whereas from strains of the genus Rickettsia, into the phenol phase. Both extracts 
are thermostable, they sediment at $105000 \mathrm{~g}$, they are of lipopolysaccharide (LPS) nature and posses certain biological properties of bacterial endotoxins (toxicity, pyrogenicity, elicitation of hypothermia in white rats). These properties are bound in strains of genus Rickettsia to LPS of so called soluble antigen. In LPS isolated from Coxiella burnetii we found components that are characteristic for bacterial LPS: ketodeoxioctonate (KDO) and heptose in the sugar component, and $\beta$-hydroximyristic acid in the lipid component.

Selection of a Chlortetracycline-Resistant Strain of Coxiella burnetii. R. BREZINA, Š. Schramek, J. KazÁr, Institute of Virology, Slovak Academy of Sciences, Bratislava.

After 10 yolk sac passages of strain Henzerling of Coxiella burnetii in the presence of increasing amounts of chlortetracycline, we obtained a variant, resistant to $1 \mathrm{mg} /$ lembryo of this antibiotic. The resistance did not change after five successive passages of the strain without antibiotic. In subsequent passages, the variant could multiply in the presence of $2-4 \mathrm{mg}$ of chlortetracycline. No changes in antigenie properties or in the phase state of the strain occurred in comparison with the original strain.

Effect of Some New Synthetic Substances on Mycobacterium smegmatis. V. Majtán, L. Drobnica, Research Institute of Epidemiology and Microbiology, Bratislava, Chair of Technical Microbiology and Biochemistry, Faculty of Chemistry, Bratislava.

In our previous study, we report d effects of antituberculous drugs on the growth and aimed metabolic processes in Mycobacterium smegmatis. The results obtained showed a relatively low sensitivity of cells of Mycobacterium smegmatis to known antituberculous drugs e.g. $p$-aminosalycilic acid, pyrazinamide, streptomycin, conteben, cycloserine, viomycin, ethambutol, kanamycin, isoniazid, ethionamide, rifampicin. In further experiments we investigated series of various synthetic substances and we found a significant effectiveness against Mycobacterium smegmatis in new isothiocyanate derivatives of amino acids, derivatives of isocrotonic acid, furylacrylic acid and also in synthetic "uncouplers" belonging to the group of carbonylcyanides. With the exception of certain derivatives, the effect of mentioned substances is due to their interference with the energy-carbon metabolism. Their mutual characteristic property is the parallel inhibition of incorporation of leucine ${ }^{14} \mathrm{C}$ and adenine ${ }^{14} \mathrm{C}$ into particular macromolecules in Mycobacterium smegmatis. These results also stress a significant relationship between the effectiveness and lipophilia of these substances.

Evaluation of Immunizing Properties of the Czech BCG Vaccine Strain Grown under Various Conditions by a Standard Method. J. Prứchová, Z. Šín, M. Mára, H. MoHeLSKá, State Institute for the Control of Drugs, Prague, Institute of Hygiene and Epidemiology, Prague, Laboratory for Special Medical Microbiology, Faculty of Medicine, Charles University, Prague.

Profound biological changes of the original BCG strain occurred during the long-term maintainance under various conditions in various laboratories throughout the 
world. In the present study we investigated differences in properties betwetn the strain cultivated in medium Sauton with asparagin (SAS) and in medium Sauton with casein hydrolysate (SH). Immunogenicity of the strains was tested by immunization of guinea pigs; the effect was evaluated by the spleen weight and Feldman's index in comparison with standard Danish BCG strain. The results were further compared with the per cent of lipids extractable by hot ethanol, present in the dry bacterial mass and with the morphological picture of cultures. Immunizing potency of the Czech BCG strain in significantly lower than that of the Danish strain. In addition, this strain cultivated on SAS possessed lower immunogenicity that the same strain cultivated on SH. The content of lipids in the Danish strain did not differ significantly from the lipid content of the Czech strain cultivated on SAS but was significantly higher than in the Czech strain cultivated on SH medium. The Danish strain was not evaluated morphologically. As regards the Czech BCG strain, it was found that the proportion of intact bacteria was by one order higher in the strain on SAS than in the strain maintained on SH. The direct dependence of immunizing potency and lipid content determined by us earlier in the Czech BCG strain on SH, is not valid for this strain on SAS where this dependence was found to be indirect.

Morphological Evaluation of the Czech BCG Strain Grown Under Various Conditions H. Mohelská, Z. Sír, J. Galliová, J. Prưchová, Institute of Hygiene and Epidemiology, Prague, State Institute for the Control of Drugs, Prague.

The aim of the present study was to evaluate morphologically the effect of environmental factors on biological properties and immunogenicity of Mycobacteriu bovis BCG. The Czech BCG strains were grown in Sauton medium supplemented with casein hydrolysate (SH) or asparagin (SAS). In addition strains were tested after one lyophilisation and subsequent cultivation in corresponding medium, or even after repeated lyophilisations. The reason of evaluation of the effect of lyophilisation is a use of a seed lot system for production, which is being introduced in several countries. The morphology of strains was studied using ultrathin sections. Pathological changes in bacteria were evaluated according to Armstrong and D'Arcy Hart (1971). We found autolytic changes in bacteria, i.e. cavitations penetrating up to the nuclear region, break of the plasmatic membrane and extrusion of cytoplasma. The ultrastructure of intact bacteria was evaluated according to Avakjan et al. (1972). The ultrastructural picture is rather complicated due to the polymorphism of the mesosomal apparatus and occurrence of vacuoles of unusual morphology surrounded by a simple membrane. These vacuoles are considered by Avakjan to be empty spaces originally filled with lipids which were extracted during the treatment of preparations. In all variants of our experiments, both intact and damaged bacteria were found; however their mutual proportion varied considerably. As shown by Průchová (this symposium), the proportion of intact bacteria in $\mathrm{SH}$ cultures was very low; it sharply increased after lyophilisation and during further cultivation it kept gradually decreasing. The curve of immunogenicity was running approximately in an opposite way. It therefore seems that future experiments might confirm an indirect relationship between these two properties, the more pronounced difference being in SH than in SAS medium. The strain obviously contains two types of bacteria: resistant with low immunogenicity and fragile with higher immunogenicity. The change in external conditions (e.g. lyophilisation) results in selec- 
tion of a resistant type of low immunogenicity. Our results are in agreement with the findings of Guld (1971) who stressad the importance of natural mutations and selection for quality of $\mathrm{BCG}$ vaccines.

Fimbriae and Their Role in the Biology of the Bacterial Cell. M. Mulczyk, Polish Academy of Sciences, Wroclaw.

The present state of knowledge on fimbriae, filamentous appandages found in several bacterial species, is reviewed. Following topics are discussed: incidence, morphology, chemical composition, fine structure, gentics, antigenic structure of fimbriae and its importance for serological identification of bacteria. Data are also presented on the role of fimbrias in the biology of the bactorial cell. Effect of fimbriae upon electrophoretic mobility, adhesive properties, phagocytosis and infectivity of bacteria is duscussed. Special attention is paid to the sex fimbriae whose synthesis is determined by the presence of fertility factor $\mathrm{F}$ and some other plasmids. Evidence is provided to show that sex fimbriae are receptors for male specific bacteriophages and serve as an organ through which phage RNA and DNA are injected into the bacterial cell. The role of sex fimbriae in transferring chromosomal and plasmid DNA in the process of conjugation is also discussed.

Analysis of Toxic Products of Corynebacterium ulcerans. A. Součková, A. SoučEK, J. Renčová, Institute of Medical Microbiology and Immunology, Faculty of Medicine, Charles University, Prague, Institute of Sera and Vaccines, Prague.

All strains belonging to the species Corynebacterium ulcerans produce a toxic D sphingomyelinase of a dermonecrotic and lethal activity. Lysogenic strains produce a toxin possessing all biological and antigenic properties which are identical with the toxin of Corynebacterium diphtheriae. The detailed study of exoproducts of type culture collection and newly isolated strains resultad in the isolation of an other toxin produced by strains ATCC 9015. This toxic protein is lethal, is not neutralized by antidiphtheric serum and does not precipitate with this serum. Contrary to diphtheria toxin, an excess of ferrous ions in cultivation medium did not inhibit the production of this toxin. In addition, differences in electric charge were revealed during separation of individual proteins on ion-exchangers. Its toxic properties were neutralized by specific antiserum.

Pathogenity of Non-Traditional Glucose-Fermenting Actinomycetes. J. Scharfen, Reference Laboratory for Pathogenic Actinomycetes, Department of Microbiology, District Hygiene Centre, Trutnov.

Recently we introduced the trrm glucose-fermenting actinomycetes for members of familia Actinomycetaceae causing human disease. Besides Actinomyces israelii, which has been traditionally known to be the causative agent of human actinomycosis, we identified further strains as primary pathogens which are responsible for systemic forms of actinomycosis: Actinomyces viscosus (1971), Arachnia propionica (1974), Actinomyces naeslundii (1975), and most recent $\mathrm{t}_{\mathrm{i}} \mathrm{y}$ Rothia dentocariosa 
(1975) which was described as human pathogen for the first time. The heterogenous group of non-traditional causative agents of human actinomycosis were until recently considered innocent harmless commensals of the oral cavity. Until now, the interpretation of their occurrence in the pathological material remains uncertain. We have found that the microscopic finding of actinomycotic microgranules in the pus, and demonstration of " $R$ " or " $N$ " forms in cultures, is of practical value for evaluation of the etiological role of these actinomycetes. Histological examination of bioptic material was of no diagnostic value. Therefore the etiological diagnosis and indication of appropriate therapy remains primarily the task of a microbiologist.

Evaluation of Seven Serological Tests for Diagnosis and Taxonomy of Bovine: Mycoplasma. K. Jurmanová, M. HáJková, Veterinary Research Institute, Brno.

Seventy antisera with various properties were used for comparative study on the sensitivity and specificity of serological tests for detection of mycoplasma. Using the box titration with 16 antigens belonging to 9 species of bovine mycoplasma, we obtained criteria for evaluation of serologic tests. Using the growth-inhibition, growth-precipitation and immunofluorescence tests we found in all sera antibodies specific to homologous antigens including taxonomically related antigens. The growth-precipitation test revealed the highest proportion of reactions among related antigens. Indirect haemagglutination, complement fixation and latex agglutination were proved to be highly sensitive for detection of non-specific antibodies whereas immunodiffusion required highly potent antisera. It was found that besides tests giving only spacific reactions, one can use even tests giving non-specific reactions provided highly potent absorbed sera were used. With respect to the fact that non-specific antibodies were found in homologous antisera, we recommend to use heterologous antisera from which the non-specific antibodies were removed and the purity was controllcd using a highly sensitive assay, e.g. indirect haemagglutination.

Occurrence of Uncommon Types of Yersinia in Man. M. Tarabčák, E. Aldová, Regional Hygiene Centre, Košice, Institute of Hygiene and Epidemiology, Prague.

Since 1969 we have been following the occurrence of Yersinia enterocolitica in our Department of intestinal diseases. In most cases stool samples were examined; less frequently even urine, blood and cther samples (ratio 15:1) were studied. Material from patients with clinical symptoms of disease prevailed over material from healthy people who were examined for preventive reasons (5:1). Annually about 22,000 samples from 11,000 individuals were examined; during the whole observation period over 120,000 samples were evaluated. Altogether 154 strains of Yersinia enterocolitica was isolated; 115 belonged to serotype 3,22 to serotype 5,4 to type 9,1 to type 34 and 12 strains could not be serologically identified. Strains of serotypes 3 , 9, 34 and serologically unidentified strains possessed typica! growth and biochemical properties. The strains of serotype 5 which were isolated between $1970-73$ and in 1975 possessed growth and biochemical properties which are typical according to literary data, for biotype 1. However, in 1974 we isolated 9 strains of Yersinia enterocolitica, serotype 5 , which fermented lactose very quickly (within $16 \mathrm{~h}$ ). Also, thesa strains could grow on deoxycholate and Endo-agar as Escherichia coli. Other 
biochemical properties corresponded to biotype 1 of yersinia. All 9 patients who contracted this serotype 5 of Yersinia enterocolitica suffered from diarrhoea but they did not report any mutual contact. Besides Yersinia enterocolitica, we could not isolate other obligatory or facultative pathogens from these patients. In one patient, a significant increase of agglutinins to homologous strain could be demonstrated. Other patients were not serologically examined. We presume that in mentioned 9 patients Yersinia enterocolitica serotype 5 was the causative agent of diarrhoea. This assumption is based on following points: (1) No facultative or obligatory intestinal pathogens were isolated besides yersinia; (2) Yersinia was isolated at the beginning of the disease and disappeared during treatment; (3) Such strains with similar properties were never isolated from healthy persons; (4) A significant increase of antibodies to isolated strain was demonstrated in one patient.

Studies on Staphylococcal Infection in Big Poultry Farms. M. Trávníček, J. Balašč́́k, State Veterinary Institute, Prešov.

The outbreak of infection in roosters and hens, reared in a big farm, caused by Staphylococcus pyogenes, is described. Septicaemia was found at the early stage of the disease; it was followed later by a chronic form which was manifested as arthritis and tendovaginitis. The disease occurred mainly in roosters after transfer into rearing rooms which housed hatching hens. From 32 roosters and 2 hens we isolated 54 strains of Staphylococcus pyogenes which fermented anaerobically mannitol and glucose, had positive plasmacoagulase and dissolved gelatin within $24 \mathrm{~h}$. Staphylococci were even isolated from seminal vesicles of roosters. The pathogenicity of isolated strains was confirmed in a biological test: 4 out of 8 broilers succumbed after experimental infection and Staphylococcus pyogenes was found at autopsy. Four surviving broilers were killed on the 14th day after infection; in one bird Staphylococcus pyogenes was demonstrated bacteriologically. The strain was sensitive to streptomycin, chloramphenicol, neomycin, erythromycin and furadantin and resistant to penicillin and tetracycline. In order to curb the outbreak of infection in the farm, antibiotics were administered to 14000 hens and 1900 roosters (furazolidon $0.02 \%$ in the fodder + erythromycin $125 \mathrm{~g} / 100$ litre of water). The antibiotic therapy was partially succesfull; $9 \%$ of roosters and $2 \%$ of hens succumbed.

Occurrence of Strains of Actinobacilli in Domestic Fowl. O. Mráz, P. Vhadík, J. BoHÁČEK, Chair of Epizootology and Microbiology, Veterinary School, Brno; State Veterinary Institute, Ceské Budějovice, Institute of Biophysics, Czechoslovak Academy of Sciences, Brno.

Since 1950 , reports on the occurrence of gramnegative rods with haemolytic activity in organs of chickens, hens and exceptionally in turkeys, can be found in the literature. The exact systematic classification of these organisms is still lacking; according to our own experience, the species-diagnosis like Pasteurella haemolytica (Actinobacillus haemolyticus) is unsatisfactory. Within the past five years, we examined 33 strains of this type which were isolated from peritoneal cavities and organs of dead chickens and from choanas of healthy birds. With respect to the fact that these strains possess general properties of the former family Brucellaceae, they do 
not require special growth factors, they can grow on McConkey's agar with crystal violet (Bio Quest), we consider them as actinobacilli. Their inability to hydrolyse urea resembles Actinobacillus haemolyticus; however, their other properties indicate that it is a special separate group of organisms. These properties include: formation of a zone of complete lysis on blood agar with sheep erythrocytes, different structure of somatic antigen, pathogenicity in 5-day-old chickens, different spectrum of natural hosts which is in fact limited to gallinaceous birds. Peculiar properties of this microbial group were noticed for a greater part by Kohlert (1968) and therefore we accepted the species opithet used in her work for a new designation of these organisms, i.e. Actinobacillus salpingitidis, comb. nov.

On the Etiology of Foul Brood. H. Križanová, Z. Koppel, J. Horváth, M. Beseda, M. Hala ̌̌a, Veterinary school, Košice.

Bacillus alvei and streptococci were isolated from the pathological material i.e. from honeycombs containing cells suspicious for foul brood. Studies on biochemical properties of strains of Bacillus alvei revealed their stability. Isolated fecal streptococci could be classified according to their biochemical properties into four biochemical types. In addition, the susceptibility of Bacillus alvei to certain antibiotics was tested. Even though Bacillus alvei was found to be highly sansitive to erythromycin and oxitetracycline, the authors do not recommend treatment of diseased bees because of the possibility transmission of antibiotics to honey.

Occurrence of Unusual and Atypical Shigella in East Slovakia. M. TARAвč́́k, Regional Hygiene Centre, Košice.

During the period $1970-74$ we isolated 1909 strains of shigella. The strains belonged to various groups: to group A $4.4 \%, \mathrm{~B} 42 \%, \mathrm{C} 2.6 \%$ and to D $51 \%$. In the group B (Shigella flexneri), the dominant type was $2 a$ followed by types $4 \mathrm{a}, 3 \mathrm{a}, 5 \mathrm{a}$ and 6 . Type 6 occurred in all three biotypes and its occurrence in East Slovakia was significantly above the average occurrence in the whole country (alltogether 71 strains were isolated). In addition, we succeeded in isolating 17 strains of the $5 \mathrm{~b}$ type which is very rare in Europe, and 10 strains of type $4 \mathrm{~b}$. Seven strains from group B belonged to mannitol-negative variant (types $2 a, 4 a)$. In the group C (47 strains) we found most frequently shigella boydii 1 (39 strains) and only exceptionally Shigella boydii types 2, 4, 5, 7 and 14. Out of 39 strains of Shigella boydii 1 , 15 belonged to mannitol-negative variants which have not been described in the literature until now. In group A, we isolated 81 strains of Shigella dysenteriae 2 and one strain Shigella dysenteriae 3. Also, the occurrence of group A shigella in East Slovakia significantly exceeds the all-nation average. Strains of groups A and C possessed high sensitivity to antibiotics against gramnegative bacteria including sulphonamides. The sensitivity of strains of Shigella flexneri and Shigella somaei was found to be similar as reported by Aldová. 
Serological Survey on the Occurrence of Leptospiroses in Certain Occupations. H. PRokopčáková, R. Pospíšil, Chair of Hygiene and Epidemiology, Faculty of Medicine, P. J. Šafárik University, Košice.

The results of our serological study demonstrated $8.8 \%$ of positive reactions with leptospira antigens in slaughtered animals in East Slovakia during 1970-72. Similar study in small rodents revealed the presence of specific antibodies to leptospira. We therefore examined 2300 employees of slaughter houses, the meat industry, cooling plants, agriculture, water supply and sewage plants, incinerators, including the control group. The highest incidence of positive reactions was found in employees of the meat industry and slaughter houses (9\%), Leptospira pomona and Leptospira grippotyphosa being dominant. The present report gives a detailed analysis of the occurrence of individual serctypes and antibody titres in all groups studied.

Biological Properties of Certain Strains of Listeria In Vivo and In Vitro. E. MENčíková, F. Patočka, A. Jirásek, M. Mára, Institute of Medical Microbiology and Immunology, Laboratory for Special Medical Microbiology. 1st Institute of Pathological Anatomy, Faculty of Medicine, Charles University, Prague.

A complex comparison of biological properties of following representative strains of Listeria monocytogenes of different serotypes was performed: (1) strain designated Brat 1 (serotype 1); (2) strain "Welshimer", originally isolated by this author from plants. Strain Bratislava 1 can be considered representative of the species possessing typical biological properties, producing toxic substance, particularly haemolysin, NAD-ase and phospholipase. The strain has a medium virulence in mice. The strain Welshimer possesses biological properties similar to those of so called F-strains of Listeria monocytogenes (Welshimer, Stuart), produces no haemolysins but possesses lipolytic activity. This strain is avirulent in adult mice. Depending on the size of inoculum, this strain is capable of a short-term (7-12 days) persistence in the infected organism while eliciting a minimal reaction (mixed nodes in the liver and spleen). Both strains possess the previously described endotoxin-like factor $\mathrm{E}_{\mathbf{i}}(\mathrm{Pa}$ točka, Mára) and they are immunogenic.

Biochemical, Toxic and Antigenic Properties of Vactors $E_{\mathrm{i}}$ Isolated from Various Serotypes of Listeria monocytogenes. B. Potužnínová, M. Mára, C. John, E. Menčíková, F. Patočka, I. Hánová, Laboratory for Special Medical Microbiology, Institute of Medical Microbiology and Immunology, Faculty of Medicine, Charles University, Prague.

Listerial factor $\mathrm{E}_{\mathrm{i}}$ isolated by Patočka and Mára (1971), using a modified etherwater procedure of Ribi for the preparation of endotoxin, and analogous to the endotoxin of listeria described later (Siddique and Srivastava, 1972, 1973) was prepared from cells of six strains of the chief serotypes of Listeria monocytogenes (Brat $1, \mathrm{~T}_{2}, \mathrm{~T}_{3}, \mathrm{~T}_{4 \mathrm{a}}, \mathrm{T}_{4 \mathrm{~b}}$, Brat 2 ). As was determined in aerated shaken cultures in tryptose media with glucose at $37^{\circ} \mathrm{C}$ ("Microferm" fermentor) the separate strains differed distinctly in their growth constants and production of factor $\mathrm{E}_{\mathrm{i}}$ related to dry weight of washed cells $(4$ to $29 \%$ ). The absolute amounts of proteins (Lowry) 
and polysaccharides (orcinol) varied in the $E_{i}$ of each strain, their proportions, however, approximated $4: 1$ in all of them. The minimal reactive dose of the edematous-erythematous reaction in the skin of rabbits was in the range of 60 to $100 \mu \mathrm{g}$. The $\mathrm{E}_{1}$ of various serotypes lowered the $\mathrm{LD}_{50}$ of mice upon simultaneous administration of infective doses of strain Brat 1. Rabbit antisera obtained by adjuvant immunization with the various $E_{i}$ agglutinated fresh sheep erythrocytes sensitized with the $\mathbf{E}_{\mathbf{i}}$. Titres of the various $\mathbf{E}_{\mathbf{i}}$ antisera differed. Immunoelectrophoresis revealed that listerial factors $E_{i}$ prepared from the six chief serotypes reacting with antiserum against $E_{i}$ of strain $T_{3}$ produced from 2 to 5 precipitation lines. The most significant precipitation line was present in reaction with samples of all serotypes tested.

Composition of Fatty Acids of Biologically Active Components and Lipid Fractions of Listeria monocytogenes. J. JuLÁk, M. Mára, D. Randová, Laboratory for Special Medical Microbiology, Faculty of Medicine, Charles University, Prague.

The detailed study of lipid substances of Listeria monocytogenes was motivated by the possible relation between their composition and the pathogenicity of this microbe. We investigated the fatty acid composition of freely and firmly bound lipids in biologically active components, namely MPA and $\mathrm{E}_{\mathrm{i}}$ factors, phenolic and TCA extracts. We found that factor MPA, freely bound lipids of factor $\mathbf{E}_{i}$, and total freely bound lipids have similar fatty acid spectra, as well as firmly bound lipids of $\mathrm{E}_{\mathrm{i}}$ factor are similar to that of phenolic extract. The application of the classical extraction and fractionation procedure of mycobacterial lipids by Anderson and Asselineau to lipids of listeria was inspirated by analogies in the pathogenic effect of listeriae and mycobacteria. We obtained the fractions analogical to fats, phosphatides, A, B, C, and D waxes, petrolether extract analogical to Cord factor, and total firmly bound lipids. These fractions were characterised by means of thin-layer chromatographic detection of total lipids, phospho-, glyco-, and aminolipids and also by gas chromatographic determination of fatty acids. From the obtained results can be seen the close relationship between fats and $A$ waxes, and between $B$ and $C$ waxes. The petrolether extract is distinctly different from any other fraction.

The Effectiveness of Detection of Listeria from Water Eluate Using Selective Media. A. Šeševičková, L. ŠeševičKa, M. VAsic, Z. Koppel, State Veterinary Institute, Michalovce, Institute of Microbiology and Zoohygiene, Veterinary School, Košice.

The present report describes detection of listeria in eluates of silage and hay. Eluates, prepared originally for chemical examination according to the Czech state standard (CSN) No. 467012 , were used in the amount of $50 \mathrm{ml}$ throughout the experiments. The eluates were filtered and adjusted to a selective medium by addition of appropriate ingredients. In addition, the original material was inoculated directly into meat-peptone broth with potassium rhodanide and into VF broth. The liquid cultivation media were incubated at $4^{\circ} \mathrm{C}$ for 3 months and at weekly intervals samples were transferred to selective media: blood agar with nalidixic acid and tripaflavine. We examined samples of silage from 5 farms and hay from 2 farms. In 121 samples examined we isolatad 14 strains of Listeria monocytogenes, serotype 4, 
a non-haiemolytic variant (in 4 farms from silage, in 2 farms from hay), the samples being taken from surface layers up to $40 \mathrm{~cm}$ deep. As regards the fifth farm, 39 strain of Listeria monocytogenes, serotype 4, non-haemolytic variant, and 29 strains, serotype $1 / 2$, were isolated from silage. In this case, the samples were obtained even from deep layers of the investigated material. The number of positive cultures was significantly higher on media containing the above described water eluates. In addition, in farms where fully virulent strains of listeria, type $1 / 2$ were isolated, cases of abortions in cattle also occurred. Bacteriological surveillance revealed heavy contamination of both animals and environment.

Antigenic Variations in Pseudomonas aeruginosa Under Natural and Artificial Conditions. B. Lányi, J. Lantos, National Institute of Public Health, Budapest, Public Health Station, Szeged.

Pseudomonas aeruginosa strains not belonging to established serogroups were isolated from patients admitted to wards where pseudomonas aeruginosa serogroup 01 and 04 predominated. Cultures similar or even more complex in antigenic structure were produced from type strains $01,04 a, 4 b$ and $04 a, 4 c$ by lysogenization. On the basis of agglutination and double agar gel diffusion $t \geq s t$, major antigenic relationships of the isolates to type strains were: (1) bilateral to 01 , unilateral to 08 ; (2) bilateral to 01 and 04 , unilateral to 08 and 010 ; (3) bilateral to $01,04,010$ and 011 ; (4) bilateral to 04 , unilateral to 01,08 and 010 ; (5) bilataral to 010 , unilateral to 01 ; (6) bilateral to 011, unilateral to 08. Immunoelectrophoresis showed that 01 and 04a, 4c derivatives belonged to the same IE-group as the corresponding parent strains, while $04 a, 4 b$ derivatives exhibited a pattarn somewhat different from the original one.

The Occurrence and Identification of Gramnegative, Non-Fermenting Bacteria (NFB) in our Laboratory. P. KоHÚt, M. Rusinko, Institut 3 of Medical Microbiology and Immunology, Faculty of Medicine, Comenius University, Bratislava.

The analysis of occurrence of NFB from various sources during the period of two years is presented. Using the modified scheme according to Pickett and Pedersen, we determined the group or species specificity of more than 300 strains. Among the strains isolated, following microorganisms were most frequent: Aerobacter calcoaceticus, group of fluorescent bacteria and miscellaneous bacteria. The value of new identification schemes of NFB for practical diagnostic purposes is discussed.

The Frequency of $R$, Col and Hly Plasmids in Escherichia coli Isolated from Healthy and Diarrhoeic Calves. A. Sokol, A. VARgovǘrková, Š. Banyat, Š. Pavlík, School of Microbiology and Zoohygiene, Vetərinary Faculty, Košice, Institut of Sera and Vaccines, Michalana, Reference Laboratory for Resistance to Antibiotics, Košice.

We examined sensitivity to antibiotics (tetracycline, $20 \mu \mathrm{g} / \mathrm{ml}$, streptomycin $20 \mu \mathrm{g} / \mathrm{ml}$, chloramphenicol, $40 \mu \mathrm{g} / \mathrm{ml}$, kanamycin $33.3 \mu \mathrm{g} / \mathrm{ml}$, ampicilin $200 \mu \mathrm{g} / \mathrm{ml}$, furadantin $50 \mu \mathrm{g} / \mathrm{mi}$, nalidixic acid $100 \mu \mathrm{g} / \mathrm{ml}$ ), colicinogenity and haemolytic ac- 
tivity in 200 strains of Escherichia coli from rectal smears of 40 healthy calves that were herded the first day, and in 60 strains from rectal smears of 20 diarrhoeic calves that had been herded for two weeks in a calf-shed in the experimental farm of the School of Veterinary Medicine, Zemplínské Teplice. We compared the mobility of determinants of resistance, colicinogeny and haemolytic activity of Escherichia coli strains of both experimental groups using a single conjugation test and triparental cross. It was established: (1) Spectrum of type markers of Escherichia coli isolated from diseased calves (gastroenteritis) who lived together for a long period, amount 18 as compared to $\mathbf{3 6}$ found in healthy, recently herded calves; (2) Most pronounced differences in the frequency of markers of strains from diarrhoeic calves $(35 \%)$ and from healthy animals $(22 \%)$ concerned the resistance to chloramphenicol; (3) The ratio of mobile : mobilised : nonmobilised determinants of chloramphenicol resistance was higher in discased calves $(85.5 \%: 8.1 \%: 6.4 \%$ ) in favour of conjugable plasmids as compared with the ratio found in healthy animals $(65.1 \%: 14.3 \%$ : $: 20.6 \%$ ). This fact suggests a faster horizontal transfer of chloramphenicol resistance (coded by plasmids) in Escherichia coli strains from calves suffering from diarrhoea, which is obviously the result of a specific selection pressure in calves treated for 2-5 days with chloramphenicol.

Explosive Occurrence of Multiresistant Strains of Salmonella typhimurium in East Slovakia. M. Tarabčák, V. KrČméry, M. Hocmanová, J. Borecká, Regional Hygiene, Centre, Kosice Research Institute of Hygiene. Bratislava, District Hygiene Centre, Michalovce, Research Institute of Epidemiology and Microbiology, Bratislava.

Within the period $1952-1974$, about 60000 strains of salmonella belonging to almost 100 serotypes, were isolated. The dominant type was Salmonelly typhimurium. Until 1973 almost all isolated salmonella were susceptible to all antibiotics tested (14 antibacterial substances have been $t \_s t e d$ since 1970). Only occasionally a strain of Salmonella enteritidis, resistant to streptomycin (S), kanamycin (K), neomycin $(\mathrm{N})$, sulfonamides $(\mathrm{Su})$ and strain of Salmonella agona, resistant to ampicilin (A), carbenycilin (Ca) or to $\mathrm{S}, \mathrm{Su}$, and very seldom a strain of Salmonella typhimurium, resistant to tetracycline (T) or C, T, A, Ca and Su respectively occurred. Since 1973 , however, we started to observe an increased number of multiresistant strains of Salmonella typhimurium in about half districts of our region; since the second half of 1974, these multiresistant strains became dominant. According to resistance to antibiotics these strains could be divided into three groups: (1) Most strains were resistant to $\mathrm{S}, \mathrm{C}, \mathrm{T}, \mathrm{K}, \mathrm{A}, \mathrm{N}, \mathrm{Ca}, \mathrm{Su}$; (2) Strains resistant to $\mathrm{S}, \mathrm{C}, \mathrm{T}, \mathrm{A}, \mathrm{Ca}$ and $\mathrm{Su}$; (3) Strains resistant to $\mathrm{S}, \mathrm{K}, \mathrm{A}, \mathrm{Ca}, \mathrm{Su}, \mathrm{N}$ (only occasionally). Using the transfer of resistance to strain of Salmonella typhimurium LT2, we demonstrated that in all groups the resistance was multivalent and transferrable by a plasmid. The strain of Salmonella typhimurium which is resistant to antibacterial substances, could not be phagotyped whereas sensitive strains could be typed by phage in almost all cases. The significance of this finding is being studied. 
Origin of Sensitivity to Antibiotics in Escherichia coli Isolated from Infants. J. HLAUčová, L. Dubay, L. Klimová, Institute of Microbiology, Faculty of Medicine, P. J. Safárik University, Košice, Infant Nursery, Košice.

We have been studying the kinetic of changes of plasmids of strains of Escherichia coli from stools of infants and employees of a nursery. We examined the resistance of strains to chloramphenicol, tetracycline, kanamycin, ampicilin, sulfonamides, further the haemolytic activity and the ability to form colicins. In the present paper, the changes in resistance (sensitivity) to antibiotics under the influence of antibiotic therapy are reported. Stool samples were inoculated on 6 media: McConkey's agar (MC), McConkey + streptomycin, McConkey + chloramphenicol, McConkey + tetracycline, McConkey + kanamycin and McConkey + ampicilin. The antibiogram (according to Bohuš) was determined in two colonies from each agar plate. From each infant 5 stool samples were examined on average. We found that administration of antibiotics resulted in changes of resistance (sensitivity) of strains; for example, rovamycin treatment induced sensitivity to chloramphenicol and kanamycin, nalidixin increased the sensitivity to tetracycline etc. The mechanism of these changes remains unknown.

Occurrence of $R$-Plasmids in Enteropathogenic Strains of Escherichia coli Isolated from Calves. J. Sabo, V. Hrušovský, Institute of Microbiology and Zoohygiene, Veterinary Faculty, Košice.

It is known that $\mathbf{R}$ plasmids are very wide-spread in Escherichia coli. $\mathbf{R}$ plasmids were found even in laboratory strains which were maintained from the pre-antibiotic era. The massive therapeutic and preventive use of antibiotics as well as the fortification of the fodder resulted in a significant increase of $R$-plasmids and thus became epidemiologically and epizootically important. We studied the occurrence of R-plasmids in Escherichia coli strains isolated from dead animals with clinical diagnosis "colibacillosis". In most strains we found multiresistance to commonly used antibiotics. We evaluated 40 strains belonging to serotypes $0101,0115,0117$. The typing was performed by a test tube method according to Salajka. Determination of $\mathbf{R}$-plasmids was performed by using a simple conjugation test, the recipient strain being Escherichia coli K $12 \mathrm{Nx}$ L85. The results of the present study suggest that $52.5 \%$ strains carry R-plasmids against commonly used antibiotics. This fact explains frequent failures of antibiotic treatment of diarrhoea of calves. Therefore we suggest repeated alternative use of antibiotic-chemotherapeutic combinations for treatment of calf collibaciloses.

Haemolysins of Enterobacteriaceae and Their Clinical Significance in Diarrhoeal Diseases. H. Puzová, L. Dubay, M. Hocmanová, E. Karabová, V. Janigová, Institute of Microbiology, Faculty of Medicine, P. J. Šafárik University, Košice; Department of Microbiology, District Hygiene Centre, Michalovce.

The determination of potential pathogenity of facultatively pathogenic enterobacteria has always been a difficult diagnostic task of medical microbiology. One of possible approaches to this problem is to detect biologically active products of 
microbes, e.g. haemolysins. Besides other enterobacteria, bacteria of the genus Proteus possess haemolysins. In addition there is a steady increase of diseases in which proteus was isolated as the only pathogenic agent. The few literary data on the pathogenic role of haemolysins of proteus are conflicting and therefore we devoted our present study to this problem. Using the quantitative assay of Nesterov and Frolov (1969) for determination of haemolysin activity, we tested 227 strains of Proteus morganii and Proteus mirabilis. Strains were isolated from stools of infants suffering from various gastrointestinal disorders. In agreement with the results of Averina (1974), our data confirmed that haemolysins play an important role in gastrointestinal disorders in infancy.

Rennet as a Source of Salmonella in Dairy Products. C. Grieger, J. Havrila, R. Hromada, G. Lengyel, M. Pakánová, R. Perl, F. Verdon, State Veterinary Institutes, Prešov and Košice, Region Vetərinary Service, Košice, District Veterinary Service, Prešov.

The microbiological examination of dairy products revealed high frequency of Salmonella agona particularly in sheep cheese and hard cheese. The source of bacteria was found to be the rennet. Therefore a large-scale bacteriological trial was organised; 1268 samples of various origin, taken in dairy industry, were examined and salmonella was found in 69 cases. The veterinary service together with other authorities succeeded to eradicate these sources of salmonella infection and thus prevent a significant increase of this serotype in the population.

\section{VIROLOGY}

Effect of $U V$ Radiation on Sensitivity of Bacteriophage to X-ray Radiation. Z, HRADEČná, D. Toufarová, Institute of Biophysics, Czechoslovak Academy of Sciences, Brno.

Sublethal doses of $\mathrm{UV}$ radiation stimulate the resistance of lambda bacteriophage to $\mathrm{X}$-ray radiation. The influence of the repair ability of the host cells was investigated. Host cells with normal and limited repair and recombination ability ( $U V r$, rec) were employed for these experiments. The increase in phage resistance to X-ray radiation was observed in all host bacteria used, although differences were found between the various hosts. The use of asriflavine, which inhibits repair by the host cells, confirmed that the increase in bacteriophage resistance to $\mathrm{X}$-ray radiation after sublethal doses of UV radiation was not influenced by the repair ability of the host cells only.

Inactivation of Transfective DNA of Phage SPP1 and Its ts Mutants by Ionizing Radiation and Alkylating Agents. M. Vízdalová, E. Janovská, V. D. Zhestyanirov, Institute of Biophysics, Czechoslovak Academy of Sciences, Brno, and Institute of Cytology, Academy of Sciences of the U.S.S.R., Leningrad. 
Injury produced in phage DNA by ionizing radiation and alkylating agents of the nitrogenous yperite type was studied in a transfective nucleic acid model. When studying these problems, the authors used Bacillus subtilis SPP1 phage, its thermosensitive mutants $\mathrm{N}_{3}$ and $\mathrm{N}_{73}$ (induced with nitrous acid) and the mutant $t_{1}$ (induced with hydroxylamine). These mutants, which were chosen from among $30 \mathrm{ts}$ mutants on the basis of complementation tests, belong to different functional groups. The sensitivity of extracellular phage to the above agents was compared with the sensitivity of isolated, biologically active DNA. The extent of the damages caused in the DNA was detected by the transfection method in competent Bacillus subtilis 168 host cells. It was found that defects induced in the phage genome by mutagenic agents had practically no influence on the extent of damage caused to the phage and its DNA by either ionizing radiation or alkylating agents. Intact phage (the wild type of phage SPP1 and its $t s$ mutants) was significantly more resistant than its DNA to $\gamma$-radiation, whereas alkylating substances damaged isolated DNA less than the corresponding phage, irrespective of whether the agent was mono-, bi- or trifunctional. The defect responsible for inactivation caused by ionizing radiation was the same as the one for inactivation caused by the monofunctional alkylating agent, i.e. simple breaks in the DNA.

Influence of the Physiological State of the Host cells and of Inhibitors of Dark Repair on the Repair of UV Radiation-induced Injury of Phage SPP1. E. JaNovsKá, M. Vízdalová, V. D. Zhestranikov, Institute of Biophysics, Czechoslovak Academy of Sciences, Brno and Institute of Cytology, Academy of Sciences of the U.S.S.R., Leningrad.

The authors studied the extent of the injury produced by UV irradiation in phage SPP1 and its isolated transfective DNA. UV-inactivated transfective DNA was repaired by the host cell less effectively than whole phage. Differences in the extent of repair could have been due to differences in the physiological state of the host cells (an exponentially growing and a competent culture). We therefore used unirradiated exponentially growing and competent cells as hosts for UV-irradiated phage SPP1. The exponentially growing culture repaired the larger phage DNA fraction, but the extent of the repair of UV-induced phage injuries was approximally the same as with competent cells. The results of further experiments demonstrated that different phage survival and DNA transfective capacity on $h c r^{+}$and hcr strains were, in fact, due to enzymatic processes of dark repair. The addition of inhibitors of dark repair to the culture medium after irradiation considerably influenced the extent of the repair of $\mathrm{UV}$-induced injuries. High caffeine concentrations inhibited bacterial growth; low concentrations did not affect the surviva! of UV-irradiated phage. On the other hand, the addition of asriflavine and ethidium bromide completely suppressed the host cell repair and there was no difference between phage survival on $h c r^{+}$and $h c r$ strains.

Genetic Map of Zone c of Pseudomonas aoruginosa Phage G 101. A. Kazdová, Institute of Biophysics, Czechoslovak Academy of Sciences, Brno.

Phage G 101 was chosen for the construction of a map of Pseudomonas aeruginosa phages, genetic research on which is in the initial stages. Type $c^{-}$(clea:) phage $G 101$ 
morphological mutants obtained by hydroxylamine mutagenesis (they are not formed spontaneously) were divided, by means of complementation, into three groups. That means that zone $c$ is composed of 3 genes. The frequency of recombination between the zone $c$ genes was determined by crossing members of the various complementation groups. The sequence of the genes was determined by means of a temperaturesensitive mutant occurring near zone $c$. It was also found that one of the zone $c$ genes is probably a repressor gene. It does not lie in the centre of zone $c$, as in lambda or $\mathrm{P} 22$ phage, but at one end of the regulation area. A further type of $c^{-}$mutant did not correspond to the two standard clear mutants, but behaved like a singlepoint mutation situated in the immediate vicinity of one of these two mutants.

Lednice (Yaba 1) Virus - Its Isolation and Study of Its Properties. D. MáLKová, V. Danielová, J. Minár, Institute of Parasitology, Czechoslovak Academy of Sciences, Prague.

Lednice virus was first isolated in Czechoslovakia in 1963, from the mosquito Culex modestus, in South Moravia. Its occurrence here was confirmed in 1972. It belongs to the Turlock arborvirus group and is antigenically very close to Yaba 1 virus. It is relatively large, is sensitive to ether and deoxycholate and tolerates an alkaline medium very well. The only susceptible laboratory animal is the albino mouse, which dies after intracerebral and intranasal administration of the virus. One-day old suckling mice are the most susceptible and susceptibility diminishes with advancing age. Other laboratory animals, e.g. the rabbit, may form antibodies. Birds of the family Anatidae develop viraemia and form antibodies (low blood levels of the virus were found in goslings and ducklings). The virus is lethal for chick embryos. Experiments on monkeys (Macaca mulatta) showed that the virus is not pathogenic for them. The virus has good antigenic properties and gives rise to complement-fixing, haemagglutinating and neutralizing antibody formation. So far, it can be cultivated in vitro only on avian fibroblasts. Seven strains, antigenically identical, have been isolated: small differences have been found only in the rate of CPE formation and in sensitivity to the $\mathrm{pH}$ and to heat.

Propagation and Distribution of Lednice Virus in the Chick Embryo. J. KRoвová, D. Málková, J. M. Kolman, J. Rujǔ́áxi, Institute of Parasitology, Czechoslovak Academy of Sciences, Prague, and Institute of Virology, Slovak Academy of Sciences, Bratislava.

Lednice virus multiplied in chick embryos (c.e.) after infection of both the chorioallantois and the yolk sac. Multiplication occurred at the site of infection and in the embryo itself. The virus titres attained the maximum $72 \mathrm{~h}$ after infection and the embryos started to die at the same time. During passage, the virus titre rose progressively and its accumulation time shortened. In a fluorescent antibody study of the spread of the virus in c.e. after infection of the yolk sac, positive fluorescence was found in the brain (neuroblasts), the spinal cord, the spinal ganglia, the striated muscles, the vascular endothelium, the myocardium and the lung mesenchyme. In the yolk sac, focal fluorescence was found in the epithelium, the endothelium of some of the blood vessels and in islands of haematopoiesis in the extraembryonal 
mesenchyme. In places corresponding to an incidence of the antigen, histological tests showed a marked exudative reaction, haemorrhage and infiltration by cells of the leucocytic series.

Propagation of Lednice Virus in Tissue Cultures. Z. Marhoul, V. Danielová, J. Krobová, D. Málková, Institute of Parasitology, Czechoslovak Ácademy of Sciences, Prague.

Lednice virus, strain 6118, was tested on primary goose (GEF), duck (DEF) and chick (CEF) embryonic fibroblast cultures. A brain virus suspension from the 2nd (M2) and 6th (M6) suckling mouse passage was used for inoculation. The virus was passaged 10 times on $\mathrm{DEF}$ and $\mathrm{CEF}$ and 5 passages with M2 and 7 with M6 were done on GEF. Undiluted medium from the previous passage was used for inoculation in subsequent passages. Multiplication of the virus in the cells was studied by inoculating suckling mice. On GEF the virus titre attained the maximum value (2 $\log$ LD $_{50}$ ) on the 3rd day after infection, but a CPE, not very pronounced, did not appear until the 7 th day, when the virus titre was already diminishing. From the 3rd passage onwards, the virus titre rose slightly and the CPE started on the 3rd day after infection; in later passages, cytopathic changes gradually became visible $24 \mathrm{~h}$ after infection already, but without a further marked increase in the virus titre. No differences between $\mathrm{M} 2$ and $\mathrm{M} 6$ were found. The results in DEF were similar. In CEF, a CPE was already formed in the lst passage, however, within $48 \mathrm{~h}$ after infection. The virus titres were higher, but fluctuated during passages. Because of this fluctuation and the low titres on GEF and DEF, an experiment to determine virus autointerference was carried out. Autointerference was demonstrated and in inoculation with a dose of virus 1,000 times smaller, a titre of up to $6 \log \mathrm{TCID}_{50} / 0.1 \mathrm{ml}$ medium was obtained. Multiplication of the virus on all three types of primary cultures was confirmed by the immunofluorescence method.

Serological Tests of a Selected Sample of the Human Population and of Domestic and Wild Animals for the Presence of Haemagglutination Inhibiting Antibodies to LedniceYaba 1 Virus in an Endemic Region of This Virus in South Moravia. J. M. KolmaN, Č. Folk, K. Hudec, J. Minár, Institute of Parasitology, Czechoslovak Academy of Sciences, and Institute for Research on Vertebrates, Czechoslovak Academy of Sciences, Brno.

Clarke and Casals's haemagglutination inhibition microtest (Clarke and Casals, 1958), modified for Takátsy's "Microtitrator", was used for serological examination. The statistically representative sample of the human population comprised 181 individuals belonging to 7 age groups. Adults whose work brought them into almost daily contact with the Lednice-Yaba 1 virus focus were chosen. Juveniles, as the relatively most susceptible category of the given population, formed a separate group. The results of the serological tests were all negative, however. Tests of 83 horses, 603 cows, 124 pigs, 50 sheep and 4 goats were likewise negative. On the other hand, antibodies were found in $3.94 \%$ of the 374 domestic geese examined and in $11.15 \%$ of the 242 domestic ducks, but the sera of 204 chickens were negative. Among 280 wild birds examined (29 species belonging to 11 families), antibodies 
were found only in aquatic birds - in $17.2 \%$ of 64 grey lag-goose (Anser anser) sera examined, in $31.88 \%$ of 68 mallard (Anas platyrhynchos) sera and in two out of four mute swan (Cygnus olor) sera. The prevalence of positive findings in the sera of wild and domestic geese and ducks, together with swans, is attributed to selective species ornithophilia of mosquitoes of the species Culex modestus, which are so far the only known specific vectors of Lednice-Yaba 1 virus.

Tettnang Virus, a Newly Isolated Virus from Ticks. V. Danielová, B. RehseKÜPPer, R. Acknrman, Institute of Parasitology, Czechoslovak Academy of Sciences, Prague, and Universitots-Nervenklinik, Köln.

In 1970, four virus strains - all identical - were isolated from tick (Ixodes ricinus) nymphs and imagoes collected during May and June in three localities in the German Federal Republic. In cross CFR, the virus did not react with any of the European tick-borne viruses, tick-borne encephalitis, Uukuniemi, Tribeč and Bhanja. Strain 63 was therefore sent to the Yale Arbovirus Research Unit for determination. Here it was tested in the CFR with 40 tick-borne arboviruses not belonging to the B arbovirus antigenic group, with negative results. The virus was entered in the arbovirus catalogue as a new virus, under the name Tettnang, according to the locality name of the prototype strain 63. This virus is pathogenic for suckling mice after intracerebral and peripheral administration; adult mice respond only by a relatively low antibody level. It does not produce a CPE on chick fibroblasts and GMK cells. The virus is sensitive to ether and sodium deoxycholate and is extremely thermolabile. It passes through a $100 \mathrm{~nm}$ filter. Attempts are now being made to explain the bearing of this virus on a neurological disease which occurs among people living in all the three localities concerned and was the reason why the virological examination of ticks was undertaken.

Isolation of Ťahyňa Virus from Culiseta annulata (Schrk.) Larvae Collected in Natural Surroundings. V. Bárdoš, J. RyBa, Z. Hubálek, Institute of Parasitology, Czechoslovak Academy of Sciences, Prague.

On July 3-5, 1974, 797 mosquito larvae (Aëdes vexans 237, Aëdes cinereus 240, Culiseta annulata 320 ) at stages $2-4$ were collected from pools at the margin of a lowland wood in South Moravia. They were all first generation larvae. Isolation experiments were carried out in a completely new laboratory box, using new instruments and freshly prepared diluent. The larvae were crushed, 10 at a time, in $1 \mathrm{ml}$ PBS diluent. The prepared suspensions were always divided into two tubes and were stored at $-65^{\circ} \mathrm{C}$ until needed for the intracerebral inoculation of 1 - to 2-day-old SPF mice. Of the 11 suckling mice inoculated with a mixture of two Culiseta annulata suspensions (LA 65 and LA 66) from the first tube, one was devoured by the mother on the 10th day. Reisolation experiments were therefore carried out with the other, still unopened tube. In a litter of 7 suckling mice inoculated intracerebrally with suspension LA $6 \tilde{5}, 5$ mice died on the 10th day, one died on the 11th and one survived. In the next passage the mice died on the 5th and 6th day. In the third passage, all the inoculated suckling mice died between the 2nd and the 6th day. The virus infection titre (in the third passage) (7.5 neg. $\log _{10} \mathrm{LD} 50 / 0.02 \mathrm{ml}$ ) was reduced with diethyl ether by over $4 \log _{10}$ units in an i.c. 
test. Hyperimmune anti-Tahyňa (prototype strain "92") mouse serum diluted in the ratio $1: 4$ neutralized over $4.5 \log _{10}$ units of the virus in an i.c. test in suckling mice. This study gives the first demonstration of the possibility of transovarian transmission of T̆ahyña virus by mosquitoes under natural conditions.

Isolation of Ťahyña Virus from the Blood of Sick Children. V. BÁRdoš, M. MEDEK, V. Kania, Z. Hubálek, Institute of Parasitology, Czechoslovak Academy of Sciences, Prague, and District Health Centre, Břeclav.

Case No. 1: H. L., a boy aged 4 years, was taken ill on Aug. 25, 1974 with acute pyrexia $\left(37.8^{\circ} \mathrm{C}\right)$, general indisposition and slight sore throat. On Aug. 26 and 27 he was found to have a temperature of $38.5^{\circ} \mathrm{C}$ and $37.8^{\circ} \mathrm{C}$ and conjunctivitis and pharyngitis. A virus sensitive to the action of diethyl ether was isolated from his blood in suckling laboratory mice. Hyperimmune anti-Tahyña (prototype strain " 92 ") mouse serum diluted in the ratio $1: 4$ neutralized over $4.5 \log _{10}$ of the virus. Neutralizing antibodies were not found in the patient's serum on the day the virus was isolated, but serum taken 2 months after the onset of the disease and diluted in the ratio $1: 24$ protected $50 \%$ of the inoculated mice against a virus testing dose of $2.7 \log _{10} \mathrm{LD}_{50}$. Case $\mathrm{No}_{2} 2 \mathrm{~K}$. R., a boy aged 7 years, was taken ill on the evening of Sept. 8,1974 , with acute fever $\left(38.8^{\circ} \mathrm{C}\right)$. The next day he was taken to the children's hospital, where he was found to have a temperature of $38.2^{\circ} \mathrm{C}$, influenza-like symptoms and a sore throat. His ESR was $28 / 60$ and his leucocyte count 4,900. A virus sensitive to the action of diethyl ether was isolated from his blood. Hyperimmune anti-Ťahyña ("92") mouse serum diluted in the ratio $1: 4$ neutralized over $3.1 \log _{10}$ of the virus. No neutralizing antibodies against $2 \log _{10}$ of the virus were found in serum taken from the patient in the acute stage, but serum taken 7 months later (examined at the same time) protected $50 \%$ of the inoculated mice, in $1: 214$ dilution, against the same dose of virus. This is the first time that a virus of the California encephalitis group has been isolated from the blood of patients examined and treated in a health institution.

Sentinel Animals Indicators of Sindbis Virus in a Natural Environment. O. КožcCH, E. ERnek, J. Nosek, M. Labuda, Institute of Virology, Slovak Academy of Sciences, Bratislava.

From 1971 to 1973 we exposed rabbits, chickens and ducks to attacks by mosquitoes in the Malacky-Rakáreñ area in West Slovakia, where Sindbis virus had previously been isolated from the brain and liver of the reed-warbler Acrocephalus scirpaeus. The animals were exposed from the beginning of June to the middle of September, when mosquitoes are most active in this region. Six virus strains were isolated from the blood of chickens and rabbits in 1971 and three strains from the blood of chickens and ducks in 1972. The blood virus titre in the blood varied from threshold values to $10^{1.1}$ i.c. $L_{50} / 0.01 \mathrm{ml}$. No clinical signs of disease were observed in the exposed animals. The identification of virus isolates was determined by VN tests in suckling mice inoculated i.c. Neutralizing antibodies were found on the 14 th to 42 nd day after exposure, in titres of $1: 16$ to $1: 256$. No virus strains were isolated in 1973. The question of the main biological vector of the virus in this region is still obscure. 
Isolation of Sindbis Virus in Slovakia: Certain Biological and Antigenic Properties of the Virus. M. Grešíková, M. Batíková, M. Sekeyová, Institute of Virology, Slovak Academy of Sciences, Bratislava.

During field studies in East Slovakia we isolated a Sindbis virus from organs of the Common hamster (Cricelus cricetus). We compared some of the biological and antigenic properties of the newly isolated virus with the prototype strain. The two strains were antigenically distinctive, antiserum to the newly isolated virus having a higher haemagglutination-inhibition titre with the homologous antigen than with the prototype strain.

Relationship of West Nile Virus to Mosquitoes under Central European Conditions. M. Labuda, O. KožUCH, M. GRešíková, Institute of Virology, Slovak Academy of Sciences, Bratislava.

In 1971 and 1972, mosquitoes were caught in selected low-lying areas for isolation experiments. During this time we examined a total of 18,183 mosquitoes in 907 isolation experiments, which were carried out on 2- to 3-day-old suckling white mice and on a stable line of pig kidney cells. A virus agent defined as strain 99 was isolated from a suspension of 20 specimens of Aëdes cantans caught in the MalackyRakáreñ area (30. 6. 1972). It was identified by means of haemagglutination-inhibition, complement-fixation and neutralization tests as West Nile virus. We studied the seasonal dynamies of mosquitoes in the Malacky-Rakáren area and found that their numbers here attained the maximum at the beginning of June. The following 9 species form the greater part of the mosquito population: Aëdes communis, Aëdes punctor, Aëdes cataphylla, Aëdes sticticus, Aëdes annulipes, Aëdes cantans, Aëdes cinereus, Aëdes vexans and Mansonia richiardii. Aëdes cantans and Aëdes annulipes were the most numerous and their numbers likewise attained a maximum at the beginning of June.

Isolation and Identification of Flaviviruses from the Blood of Birds Caught in Slovakia and Moravia. E. Prazniaková, M. Grešínová, M. Sereyová, Institute of Virology, Slovak Academy of Sciences, Bratislava.

In 1973, Dr. Ernek's team collected 29 blood samples from 7 species of birds in the basin of the rivers Ipel, Dolná Rimava and Bodva. From the blood of Tringa ochropus, Vanellus vanellus and Streptopelia turtur, they isolated 3 strains of West Nile virus. In 1967, on the basis of serological surveys in Slovakia and of the finding of antibodies to West Nile virus, the hypothesis of the presence of group B arboviruses in Central Europ?, apart from tick-borne encephalitis virus, was expressed. The isolation of West Nile virus from birds' blood and from mosquitoes (Aëdes cantans) confirmed this hypothesis. In 1974 we collected 35 blood samples from 10 species of birds in the Lednice area. From the blood of Tringa ochropus we isolated a virus which was identified in a haemagglutination-inhibition test and complement-fixation test as tick-borne encephalitis virus. Serological surveys among migratory and aquatic birds in 1974 drew attention to the high prevalence of tick- 
borne encephalitis virus ( $37 \%$ of the avian sera examined reacted with tick-borne encephalitis antigen). The significance of birds as hosts of Flaviviruses, with special reference to the possibility of chronic infection, is still an open question.

Serological Surveys shouing West Nile Virus in Some Parts of Central Europe. M. SEKeyová, M. Grešíková, M. Batíková, Institute of Virology, Slovak Academy of Sciences, Bratislava.

The presence of arboviruses in human and animal sera was studied by means of haemagglutination-inhibition tests in Slovakia and, for comparison, in several other parts of Central Europe. Serological surveys carried out by random sampling among healthy human population in Slovakia showed the presence of antibodies to West Nile antigen in a small percentage of cases $(2 \%-4 \%$, according to the locality). Antibodies to West Nile virus were found in $8.5 \%$ of bovine sera. The highest percentage of antibodies to West Nile virus was found in canine sera. Serological survey in Austria yielded similar results. Antibodies to West Nile virus were found in $2 \%$ to $5.8 \%$ of human population and in $26.7 \%$ of bovine sera. The highest percentage of positive reactions was obtained in canine sera $(33.3 \%)$. The above findings, together with the isolation of West Nile virus from mosquitoes (Aëdes cantans) and from the blood of aquatic birds, suggest the circulation of West Nile virus in Central Europe also.

Comprehensive Serological Analysis of Human Infections with Tick-borne Arboviruses. H. Libíková, F. Heinz, D. Ujházyová, Institute of Virology, Slovak Academy of Sciences, Bratislava; Regional Hygiene Centre, Ostrava, and First Neurology Clinic, Faculty of Medicine, Comenius University, Bratislava.

The sera of patients with meningoencephalitis after tick-bite or with polyradiculoneuritis were repeatedly examined in neutralization tests with a cytopathic variant of tick-borne encephalitis virus (TEV, on a pig kidney cell line), in complement fixation tests, in plaque neutralization tests with Lipovník virus (LV) of the Kemerovo group and in neutralization tests with herpes simplex virus type l (HSV 1), in both cases on primary chick embryo cell cultures. The first two viruses have a relationship to ticks of the species Ixodes ricinus. In the case of HSV 1, only an increase of the antibody level or titres of $1: 512$ or over were evaluated. None of the patients had herpes labialis. $16 \%$ of patients with meningoencephalitis had no TEV antibodies, but displayed conversion or an increase in the LV antibody titre, or also a significant response for HSV 1. Almost two thirds of the cases confirmed serologically as TE responded significantly also for LV and over one third for HSV 1. One quarter of the patients reacted serologically with all three viruses. Very high HSV 1 levels, together with TEV serum positivity, were also recorded in cases of polyradiculoneuritis. The kinetics of the serological response to the viruses in question took effect simultaneously, or in different sequences. The results are discussed with reference to the significance of viruses of the Kemerovo group in human pathology and to the possible pathogenetic consequences of the simultaneous occurrence of several virus infections for the organism. 
Infection of Ferrets with Tick-borne Encephalitis Virus. K. Drábrová, M. ŚTÁREK, A. JiRÁser, Institute of Sera and Vaccines, Prague, and First Department of Morbid Anatomy, Faculty of Medicine, Charles University, Prague.

The amount of information on the susceptibility of ferrets to tick-borne encephalitis virus is very small. We therefore studied young ferrets infected subcutaneously or intracerebrally with this virus (strain Hypr). The experiments showed that subcutaneous infection produced no clinically manifest signs of the disease. Isolation tests likewise failed to demonstrate the presence of the virus in the brain, spleen or other organs of infected animals. In intracerebral administration, we studied the dynamics of virus replication in correlation to time and the size of replication in correlation to the dose. These experiments showed that tick-borne encephalitis virus multiplies in the ferret cerebrum and produces extensive, histopathologically clearly demonstrable encephalitis; lesions in the cerebellum are extremely small. In a dose of $0.1 \mathrm{ml}$ (always administered into the right hemisphere), the amount of infectious virus varied from $10^{1}$ to $10^{4}$ EID 50 . After the maximum dose, the amount of virus isolated from the brain attained the maximum on the 12 th day. This was determined by titration in chick embryos after inoculation of the yolk sac. On the 10th day after infection, the minimum dose of virus still capable of producing encephalitic lesions and of allowing replication of the infective agent was $10^{1.5} \mathrm{EID}_{50}$. As after subcutaneous injection, no clinical signs were observed after intracerebral administration, despite the extensive brain lesions.

Incorporation of ${ }^{3} \mathrm{H}$-thymidine into Human Diploid Cells Infected with Tick-borne Encephalitis Virus in Iso- and Nonisotonic Medium. H. Babková, M. Stárek, Institute of Sera and Vaccines, Prague.

The authors describe further features characteristic for the attenuated and virulent strain of Tick-borne encephalitis virus, which could help to explain the mechanism of replication of the virus and make some of the processes associated with vaccine preparation and control easier. Characteristic differences in the glycolytic metabolism of human diploid cells infected with the virulent or attenuated virus strain and changes in lactate-dehydrogenase (E.C. 1.1.1.27) activities in cells infected with one or the other strain are also described, together with differences in the incorporation of ${ }^{3} \mathrm{H}$-thymidine into human diploid cells infected with the attenuated or the virulent strain, during replication of the virus in iso-, hypo- or hypertonic medium. Cells infected with the attenuated strain in isotonic medium incorporate less ${ }^{3} \mathrm{H}$-thymidine than uninfected cells, while cells infected with the virulent strain incorporate more. In both cases the changes occur at approximately the same time -8 to $16 \mathrm{~h}$ after infection. A similar situation was found in cells cultivated in hypertonic medium. In hypotonic medium, on the other hand, the situation is reversed, i.e. cells infected with the attenuated strain incorporate more ${ }^{3} \mathrm{H}$-thymidine than the control cultures, while infection with the virulent strain leads to lower incorporation than in uninfected cultures, again in the same interval (8 to $16 \mathrm{~h}$ after infection). 
Immunological Correlation of Immune Sera against Nucleocapsid, Envelope and Whole Herpes Simplex Virus Type 1. J. LEššo, L. HÁNA, J. Matrs, Institute of Virology, Slovak Academy of Sciences, Bratislava.

The authors describe the preparation of rabbit immune sera against naked particles, envelope and whole herpes simplex (HS) virus, to determine the correlations between formation of the various antibodies. For this, the immunoprecipitation, neutralisation and complement-fixation methods were used. It was found that immune rabbit serum against naked particles (and against formalin-treated naked particles) had a very low neutralizing antibody titre, although the complementfixing antibody was higher. Immune serum against the virus envelope had both a high neutralizing and complement-fixing antibody titre. Human serum with a high neutralizing antibody titre for a comparison was also used. The immunoprecipitation results showed that whole HS virus reacted by a single faint precipitation zone with the antibodies in serum obtained by immunization with naked particles of virus, by two precipitation zones with antibodies to the virus envelope, by two pronounced precipitation zones with human serum and by several precipitation zones with antibodies to the whole virus. The virus nucleocapsid reacted with antibodies to the nucleocapsid and by a faint precipitation zone with antibodies to the virus envelope. The virus envelope reacted by two zones with antibodies to the virus envelope, by two to three zones with antibodies to the whole virus and by one faint zone with antibodies to naked virus particles. Human serum reacted by a single zone with the virus nucleocapsid and two marked zones with the envelope and with whole virus.

Antibody Levels against Herpesviruses, with Special Reference to Epstein-Barr Virus, in the Serum of Children with Certain Diseases of the Lympho-haematopoietic Tract. J. Holý, O. Hrodek, J. ŠraJer, J. Bittnerová, J. Nyklesová, Research Institute for Child Development, Faculty of Paediatrics, and Second Children's Clinic, Faculty of Paediatrics, Prague.

Antibodies to herpes viruses were determined in the sera of 60 children with various diseases of the lympho-haematopoietic tract over a 3 years period (1972 to 1974) in the Second Children's Clinic of the Faculty of Paediatrics, Prague. Antibodies to the virus capsid antigen of Epstein-Barr virus (EBV/VCA) were examined by the indirect fluorescence method and antibodies to soluble EBV antigen, herpes simplex type 1 virus, varicella-zoster virus and cytomegalovirus by the complementfixing method. The results in the individual groups of sick children were analysed on a small digital calculator by one way analysis of variance of the root-transformed values and were compared with each other and with a control group of healthy schoolchildren. Antibodies to soluble EBV antigen found only in isolated cases, in all the groups. In children with Hodgkin's disease (H.d.), antibody titres to EBV/VCA were significantly higher than in the children in the other groups and in the control group. During the evolution period of H.d. in the patients in question, these antibody titres were not significantly higher than in the remission period. Study of the correlation of the EBV/VCA antibody level to the clinical stages of H.d. showed that it was significantly higher in patients in the IVth clinical stage, expressing the most extensive involvement of the whole organism, compared with all the other stages, which did not differ significantly from each other. Where groups of patients divided according to the histological subtypes of H.d. differed from the control group, the difference between them was not significant. 
Immunization against Marek's Disease using Virus-specific Antigens free from Infectious Virus. F. LEšník, J. N. Ross, Department of Infectious Diseases, University of Veterinary Medicine, Košice, and Houghton Poultry Research Station, England.

Immunity to Marek's disease was studied by using non-infectious materials extracted from cells infected with attenuated Marek's disease virus by means of nonionic detergents. One-week-old chicks were vaccinated with cell extract emulsified with complete Freund's adjuvant. One week later they were revaccinated without adjuvant. Antibody-free Rhode Island Red chicks were employed. A protective effect against natural infection was observed only in chicks immunized with both soluble antigens (not sedimented at $100,000 \mathrm{~g} / 2 \mathrm{~h}$ ) non-soluble antigens present in Nonidet $\mathrm{P} 40$ extract. The results show that immunogenic antigens can be partially solubilized with $0.5 \%$ Nonidet P-40 and that immunity to oncogenic Marek's disease is directed against the Marek's disease virus itself.

Persistent Herpes Infection of BHK Cells in Absence of Specific Antibodies. J. SzÁNTo, J. Leššo, V. Lackovič, Institute of Virology, Slovak Academy of Sciences, Bratislava.

Persistent infection of BHK cells was induced with 5 strains of herpes simplex virus (HSV) type 1 and with one strain of type 2. Two strains of type 1 and one strain of type 2 produced acute infection only. Attempts to induce persistent infection in HeLa and rabbit lung cells failed. Persistent infection of BHK cells was induced in the absence of specific herpes antibodies. The persistent infection was confined in three cell lines to a few months whereas in the three others the infectious HSV was demonstrated continuously. BHK cells were proliferated in persistently infected cultures, but a CPE always appeared 4-6 days after reinoculation, although it did not cause general destruction of the cells. Cells from persistently infected cultures were more resistant to superinfection with homologous and heterologous HSV than normally infected BHK cells, irrespective of whether they contained infectious HSV or not. No interferon activity was recorded in persistently infected cultures. This does not exclude the possibility that interferon may play a role in our system, since intracellular interferon can still be highly active in amounts which cannot be demonstrated. The results of infectious HSV titration were in agreement with the demonstration of fluorescent HSV antigen. The amount of antigen in persistently infected cultures was directly correlated to the amount of infectious virus produced. In cells in which no infectious HSV could be demonstrated, fluorescent antigen could not be demonstrated either. However, antigen was demonstrated in the cells in the presence of very low HSV infection titres. The cytological picture was characterized by degenerative changes of varying degrees in a monolayer culture of cells persistently infected with HSV. In some cell line-passages the degree of these changes was small and in the cell monolayer of two lines were observed small groups of multinuclear cells with changes characteristic for herpes infection in their nuclei. In the other lines, round cell degeneration was observed in the monolayer. Some intact cells were always present in persistently infected cultures, however. 
Reactivation of Infectious Bovine Rhinotracheitis Virus by Corticosteroids. V. KABELík, B. Horyna, J. Trenkát,

The course of infection with IBR virus and its reactivation was studied in 3 experimentally infected, weaned calves and in 3 cows from naturally infected stock. The calves were infected intranasally, intratracheally and by contact. 20, 41 and 105 days later in the primarily infected calves, and in the cows, immunosuppression was carried out with dexamethazone acetate salt, which was administered in a series of 6-7 intramuscular injections. The presence of virus was determined in nasal, conjunctival and vaginal secretion samples and in the blood or organs on calf kidney diploid cells and by immunofluorescence. The course of the disease in all the infected calves was characterized by clinical signs of rhinotracheitis lasting mostly 9 days. The virus titre in the nasal secretion $2-3$ days after the increase in temperature attained values of $10^{5.5}$ to $10^{6.5}$. The titre in the conjunctival secretion was much lower $\left(10^{0.5}\right.$ to $\left.10^{3.5}\right)$. The virus was demonstrated in the calves' blood on the 1 st, 3rd, 5th and 6th day after infection. Immunosuppression was followed, in both calves and cows, by excretion of the virus in the nasal secretion, where its titre rose abruptly to $10^{4}-10^{6}$. The virus was not demonstrated in vaginal secretion. Antibudy levels in calves were unaffected by immunosuppression and ranged from $1: 32$ to $1: 64$. In cows they rose significantly, however, from $1: 2-1: 4$ to $1: 16-1: 32$. In two calves slaughtered at the peak of the infection, with signs of rhinitis and conjunctivits, the virus was demonstrated chiefly in the nasal cavity, the trachea, the conjunctival secretion, the retropharyngeal lymph nodes, the lungs and the brain.

Interaction of Herpes Simplex Virus Type 1 with Multiplication of Type 2. J. RovBal, D. Zelená, Institute of Sera and Vaccines, Prague, and Institute of Hygiene and Epidemiology, Prague.

Chick embryo fibroblasts are non-permissive for most type 1 strains of herpes simplex virus (HSV), whereas rabbit embryo fibroblasts are permissive for both types. In coinfection of these types of cells with both types of HSV, type 1 inhibits multiplication of type 2. Inhibition is not mediated by interferon and evidently depends on expression of at least part of the type 1 genetic information. The capability of type 1 HSV to interfere with type 2 is inactivated by UV light and functions only in the early phases of infection with type 2 .

Peroral Infection with Rabies Virus and Peroral Anti-Rabies Immunization of European Red Foxes (Vulpes vulpes crucigera). S. Švrč́k, O. J. VRTiak, R. AleXander, R. OndREJKa, J. Závadová, University of Veterinary Medicine, Košice, and Institute of Experimental Veterinary Medicine, Košice.

1. Peroral infection with rabies virus. In the control group (European red foxes and domestic cats) infected intramuscularly with a street strain of rabies virus in a dose of 1,000 MICLD $_{50}, 100 \%$ mortality was observed. Among 24 animals (12 foxes and 12 cats) infected perorally with a dose of $1,000,000$ MICLD $_{50}, 6$ animals $(25 \%)$ died (4 cats and 2 foxes). No differences were recorded between intramuscularly and 
perorally infected animals as regards the distribution of rabies virus in the CNS, its detection in the cornea and its titre in the brain and the submandibular salivary glands. 2. Peroral immunization against rabies. The suitability of various types of vaccine for peroral immunization was verified in model experiment on guinea pigs and rabbits. Active cellular vaccine prepared from the Vnukovo-32 strain proved to be the most satisfactory. In peroral administration to foxes it is harmless, even in large doses $\left(150 \mathrm{ml}=158,115,000 \mathrm{MICLD}_{50}\right)$. In experiments on foxes immunized perorally with active cellular Vnukovo-32 vaccine (titre $10^{-4.5}$ ) in a dose of 10 or $30 \mathrm{ml}$, neutralizing antibodies were detected in $80 \%$ of the immunized animals After challenge with the street strain in a dose of 1,000 MICLD $_{50}$ (mortality in the control group $100 \%$ ), $80 \%$ of the perorally immunized animals were protected. Some of the findings (peroral infection of foxes, intravital detection of rabies antigen and peroral immunization) are of primary importance.

Results of Experimental Use in Man of Inactivated Cellular Antirabies Vaccine from the Strain Vnukovo-32. T. Mittermayer, Š. Šrrěek, O. J. VRtiak, M. A. Selimov, T. A. Akseonová, K. Žufgová, R. Alexander, J. Závadová, R. Ondrejka, Infectious Diseases Clinic, Faculty Hospital, Košice, Institute of Experimental Veterinary Medicine, Košice, and Institute for Poliomyelitis and Virus Encephalitis, Academy of Medical Sciences of the U.S.S.R., Moscow.

With the agreement of the Ministry of Health of the Slovak Socialist Republic, we undertook the experimental immunization of human subjects with inactivated cellular anti-rabies vaccine prepared from Strain Vnukovo-32. The vaccine was evolved by the above Soviet institute and was supplied under the terms of current cooperation. We started to use the vaccine on human beings in 1971 and have so far immunized 183 subjects with it. The vaccine was used for pre-exposure immunization (for workers whose employment exposes them to the danger of infection with rabies virus), according to our own scheme $(4.5-5 \mathrm{ml}$ on each of 3 successive days, with revaccination on the 30 th day). 28 subjects were immunized in this way. In some of them we titrated anti-rabies antibodies in a neutralization test in mice and also titrated nonspecific CF antibodiss by the indirect immunofluorescence method. In 60 cases the cellular vaccine was used for post-exposure immunization; these subjects had been primarily immunized with a Czechoslovak brain vaccine. Specific and nonspecific antibodies were also titrated in some (16) of these subjects. In 95 cases the cellular vaccine was used for post-exposure primary immunization and revaccination. The above serological tests were done in 17 of these subjects. The results of immunization with this vaccine were evaluated positively in WHO document No. VI on rabies. Because of its harmlessness and high antigenic activity, we recommend that this vaccine should be used on a larger scale.

Preparation of Rubeola Virus Haemagglutination Antigen and Antibodies for the Haemagglutination-Inhibition test $(H I T)$. P. Ragač, A. Hrbka, Institute of Sera and Vaccines, Prague, Sarišské Michalany Laboratory.

Our aim was to prepare standard rubeola haemagglutination antigen and hyperimmune serum for the HIT. We tried several ways of preparing the antigen. Antigen prepared by Tween-ether extraction and antigen extracted by means of a $0.1 \mathrm{M}$ 
glycine-NaOH buffer system had a high titre, but both these methods were timeconsuming. The best method was one in which the combination of antigen with haemagglutination inhibitors was broken up by versene and the separated antigen was concentrated by high speed centrifugation. With this method, using a haemagglutination macrotest, we attained titres of $1: 256-1: 512$. Hyperimmune sera were prepared by immunizing rabbits with concentrated virus suspension purified by fractionated centrifugation. For treating the sera we tried the kaolin and the heparin method. The serum haemagglutination-inhibition titres ranged from $1: 1,024$ to $1: 4,096$. The results were employed as the basis for the elaboration of a method for the pioduction of a commercial rubeola virus diagnostic preparation for the HIT.

Problems of Receptor-destroying Enzyme Production. A. Hrika, Institute of Sera and Vaccines Prague, Šarišské Michalany Laboratory.

The conditions of receptor-destroying enzyme (RDE) production by cholera bacteria were studied, using 8 Vibrio cholerae strains. The amount of RDE was titrated by means of the destruction of receptors for the adsorption of influenza virus on red blood cells. RDE production was studied in liquid media. The amount produced by the various strains depended on the quality of the medium. If a less satisfactory medium was used, the RDE titres varied widely, from 0 to 128 . In time, we evolved our own liquid medium, which contains components of Earle's solution, lactalbumin hydrolysate and peptone. Optimum RDE production was achieved in stationary surface cultures. The amount of RDE formed depended on the quality of the peptone used in the agar medium for subcultivation of Vibrio cholerae and in the production medium. By choosing suitable peptones we attained RDE titres of 4,096. This concentration is sufficient to remove haemagglutination inhibitors from anti-influenza and anti-parotitis sera on using one part RDE to 3 parts serum.

Protective Capacity of ts and tr Mutants of an $A_{0}\left(N W S \times A_{2}\right)$-Singapore Recombinant. B. Doležalová, E. Tučková, V. Vonka, M. Śtárek, Institute of Sera and Vaccines, Prague.

A tr mutant was isolated from a recombinant strain NWS/Singapore by progressive adaptation to higher temprratures. Two ts mutants were isolated from the same strain by induction with 5-fluorourasil. The protective capacity of the mutants was investigated in mice immunized intranasally with the given variants and then challenged with strains $A_{2} /$ Singapore and $A_{0} / W S$. The dynamies of the progressive induction of protection and the correlation of the degree of protection to the immunizing dose were studied. The results showed that the recombinant induces protection against both parent strains, but that protection arainst $A_{2} /$ Singapore is induced more quickly and more effectively than against $A_{0} / W S$. Despite the relatively high protective effect, the serum antibody level romains low. Another immunity factor, different from anti-heuraminidase and anti-hasmagglutinin antibodies, probably participates in this case. 
Subtypes of Australia Antigen. L. Mikula, M. Kunay, Department of Haematology and Blood Transfusion, Faculty of Medicine, University of Košice.

Australia antigen accompanying hepatitis B (new designation HBAg) occurs in three genetically determined forms. Each of these possesses "common" specificity, $-a$, which is found in all HBAg positive sera. In addition, two other specificities, $-d$, and $-y$, have been described. Each of these reciprocally excludes the other, thereby confirming their allelism. Each antigenic subtype can be further subdivided into a number of subunits of diminishing antigenic strength. The authors describe their own modification of the determination of Australia antigen subtypes, using counter-immunoelectroprecipitation in agar gel. They also evaluate the epidemiological aspect, showing that the source of infection, in the presence of an incidence of hepatitis B, can be deduced from the distribution of given subtypes.

Use of Polyethylene Ampoules in Virology. V. BÁRdoš, Z. HubÁlek, Institute of Parasitology, Czechoslovak Academy of Sciences, Prague.

The infection titre of Tahyña arbovirus in suspension did not fall dưring 190 days' storage at $-65^{\circ} \mathrm{C}$ in electrically sealed $2-\mathrm{ml}$ polyethylene (PE) ampoules (Koh-inoor, Dalečín) and did not differ from the infection titre of the same virus stored in glass ampoules under the same condition. When Ťahyňa virus was stored in PE ampoules in liquid nitrogen $\left(-196^{\circ} \mathrm{C}\right)$, the infection titre 10 months later likewise showed no significant decrease. PE ampoules are physically resistant to temperatures of $-65^{\circ} \mathrm{C}$ to $-196^{\circ} \mathrm{C}$. The technique of storing virological material in sealed $\mathrm{PE}$ ampoules in liquid nitrogen has a relatively wide range of uses (storage of virus suspensions, of arthropods and fragments of vertebrate viscera and blood samples for isolation experiments, of serum for serological tests and even of tissue cultures) and is especially satisfactory for field work. It is safer than glass ampoules for the storage of virulent material and can be recommended for practice. 